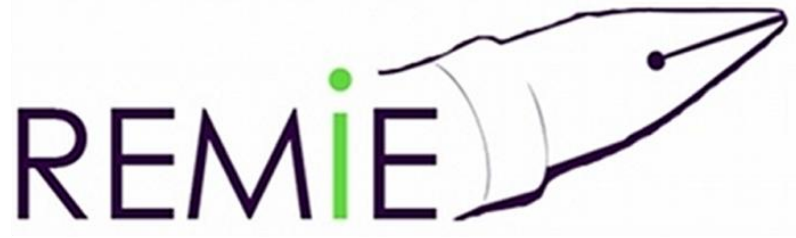

\title{
Multidisciplinary Journal of Educational Research
}

\section{Volume 8, Number 2}

\section{Hipatia Press \\ www.hipatiapress.com}

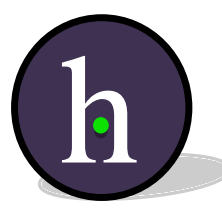

Learner Autonomy in Language Learning: Syrian Refugee EFL

Learners' Perceptions and Readiness - Nilcan Bozkurt \& Fadime Yalcin Arslan.

Iranian EFL Teachers' Emotional Intelligence and their Use of Speaking

Articles Strategies - Karim Shabani \& Arezu Ghodrati.

International Theatrical Educational Programs: Moscow Art Theatre School Experience - Elena Viktorovna Burdenko, Irina Artsis \& Natalia Ilyushchenko.

La Emancipación en Educación Ambiental: Formación en una Universidad Brasileña - Daniela Cassia Sudan \& Vânia Gomes Zuin. 


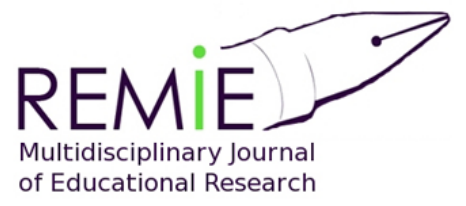

Instructions for authors, subscriptions and further details:

http://remie.hipatiapress.com

\section{Learner Autonomy in Language Learning: Syrian Refugee EFL Learners' Perceptions and Readiness}

Nilcan Bozkurt ${ }^{1}$, Fadime Yalcin Arslan ${ }^{1}$

1) Gaziantep University. Turkey

Date of publication: June $15^{\text {th }}, 2018$

Edition period: June 2018 - October 2018

To cite this article: Bozkurt, N., Yalcin Arslan, F. (2018). Learner Autonomy in Language Learning: Syrian Refugee EFL Learners' Perceptions and Readiness. Multidisciplinary Journal of Educational Research, 8(2), 115145. doi: $10.17583 /$ remie.2018.3028

To link this article: http://dx.doi.org/10.17583/remie.2018.3028

\section{PLEASE SCROLL DOWN FOR ARTICLE}

The terms and conditions of use are related to the Open Journal System and to Creative Commons Attribution License (CC-BY). 


\section{Learner Autonomy in Language Learning: Syrian Refugee EFL Learners' Perceptions and Readiness}

Nilcan Bozkurt

Gaziantep University
Fadime Yalcin Arslan

Gaziantep University

\section{Abstract}

This study examined Syrian refugee English as a Foreign Language (EFL) learners' perceptions regarding learner autonomy as well as their readiness for autonomy in English language learning. It also investigated the effects of grade and gender on learners' perceptions. A mixed-method research design was utilized, and findings indicated that neither grade nor gender had caused statistically significant differences in terms of Syrian refugees' perceptions of learner autonomy in language learning; nevertheless, both had caused statistically significant differences in terms of sub-scales. While the $8^{\text {th }}$ graders in this study perceived themselves as being more autonomous in terms of experience in language learning, the female students seemed more autonomous in terms of their perceptions of the role of teachers and feedback. Additionally, although the learners' perceptions regarding autonomy were slightly lower than their readiness for autonomy, there was a statistically significant relationship between their perceptions of learner autonomy and their readiness for autonomy in language learning. When their perceptions about learner autonomy increased, their readiness for autonomy also increased.

Keywords: autonomous learner, English as a foreign language, learner autonomy, refugee EFL learner 


\section{Autonomía del Aprendiz en El Aprendizaje de Un Idioma: Percepciones y Disposición de Refugiados Sirios en EFL}

Nilcan Bozkurt

Gaziantep University
Fadime Yalcin Arslan

Gaziantep University

\section{Resumen}

Este estudio examinó las percepciones de refugiados de Siria que estudian el inglés como Lengua Extranjera (EFL, por sus siglas en inglés) respecto de la autonomía del alumno, así como su disposición para ser autónomo en el aprendizaje del idioma inglés, y los efectos del grado y el género sobre las percepciones de los estudiantes. Se utilizó el método mixto, y los resultados indicaron que ni el grado ni el género causan diferencias estadísticamente significativas en términos de las percepciones de refugiados sirios sobre la autonomía del alumno al aprender idiomas; sin embargo, ambos causaron drásticas diferencias estadísticas en términos de sub escalas. Los estudiantes de $8^{\circ}$ grado se percibieron como más autónomos en términos de experiencia en el aprendizaje de idiomas, mientras las estudiantes parecían más autónomas en términos de la percepción que tenían sobre el papel de los maestros y la retroalimentación. Las percepciones de autonomía fueron ligeramente menores que la disposición para la autonomía, pero hubo una relación estadísticamente significativa entre percepciones de autonomía y su disposición de autonomía en el aprendizaje del idioma. El aumento de las percepciones de autonomía aumentó la disposición de los aprendices para autonomía.

Palabras clave: aprendiz autónomo, inglés como lengua extranjera, autonomía del alumno, aprendiz de EFL refugiado 
he movement of thoughts over previous years in education has shifted the center of teaching and learning from traditional methods, in which the teacher is the controller, to modern methods, in which learner is in the center of the education process. Especially in the late 1980s, learner-centeredness meant actively engaging learners in their learning processes (Nunan, 1989). Parallel to this principle, the idea of learner autonomy has maintained an important place in education. The concept of learner autonomy denotes enabling learners to take control of their learning not only in class but also in daily experiences (Benson, 2001; Little, 1996, 2007).

English teachers are essential to the development of learner autonomy, as they are responsible for creating a classroom culture that develops learners' abilities to behave autonomously (Barfield et. al., 2001); thus, teachers should be eager to play more challenging and different roles than in traditional learning, as they are the guiding figures (Benson, 2009). Language teachers, in particular, who have students from refugee backgrounds, play a significant role in supporting these students' potential for autonomy. This is because refugee students live in complex and difficult situations having left their homes by force and taken the risk of creating new lives elsewhere (Fong, 2004). Refugee learners bring "not only their local experiences into the classroom, but also their memories of experiences in their native country and their own visions of the future they desire in their new country" (Norton, 2000, p. 134). If the main aim of education is to prepare learners to address the demands of everyday life, firstly they should know how to interpret the world and express their emotions and ideas about it. As expressing oneself is made possible through language, language teachers (especially English language teachers whose missions are to teach the international language) play crucial roles in preparing students for autonomous language learning. In this way, teachers are expected to create a classroom learning atmosphere that supports learner autonomy by taking into consideration learners' needs and expectations. This initially may involve the investigation by teachers of their learners' perceptions and secondarily an assessment of students' readiness in order to increase their awareness regarding the benefits of autonomous learning. Behaviors are controlled by experiences and beliefs, and learners' beliefs can contribute to 
or hinder their potential for autonomy (Cotterall, 1995a.). To illustrate, Horwitz (1987) claims that one's having wrong beliefs about learning a language may result in his/her applying less efficient learning methods. This means that it is beneficial for teachers to recognize the beliefs and perceptions of learners in order to assess these learners' readiness for autonomy and adjust their teaching and learning processes accordingly (Cotterall, 1995b.).

The present study's participants and subject deem it as significant, as studies investigate refugees in terms of autonomy in English language learning. Thus, this study contributes both to the field of refugee studies and to the language-teaching field. It investigates Syrian refugee learners' perceptions regarding autonomy in English language learning as well as their readiness for autonomy. It also explores the relationship between these learners' perceptions about autonomy in language learning and their readiness for it. It is assumed in this study that an autonomous environment in classes can be possible by increasing the awareness of teachers and learners regarding the potential for autonomy among learners. This research responds to the research questions below:

(1) Does grade $\left(6^{\text {th }}, 7^{\text {th }}\right.$ and $\left.8^{\text {th }}\right)$ cause a significant difference in terms of Syrian refugee learners' perceptions of learner autonomy in English language learning?

(2)Does gender play a significant role in shaping Syrian refugee learners' perceptions of learner autonomy in English language learning?

(3) Does a statistically significant relationship exist between Syrian refugee learners' perceptions of learner autonomy and their readiness for autonomy in English language learning? 


\section{Literature Review}

\section{Learner Autonomy and Readiness for Autonomous Language Learning}

The meaning of the term "learner autonomy" has differed among education researchers; however, several definitions present clear ideas about this term (Zou, 2011). According to Holec (1981, p.3), regarded as the father of the field of language learning, "learner autonomy is the ability to take charge of one's learning". Autonomy - "feeling free and volitional in one's actions" (Deci, 1995, p.2) - is an essential need for human beings. It also denotes ability and is as relevant to learning as to any other aspect of life. "This ability is not inborn but must be acquired either by 'natural' means or (as most often happens) by formal learning, i.e. in a systematic, deliberate way" (Holec, 1981, p.3). Teaching and learning a language is occurs by means of an extensive process in which language is autonomously learned and taught (Quinn, 1974). Language learning is a never-ending process that wants learners to acquire how to develop autonomy and responsibility for their learning in all fields of their lives. Therefore, autonomy should be considered from different angles.

Many scholars have examined the relationship between autonomy and learners' readiness (Cotterall, 1995; Karabıy1k, 2008; Koçak, 2003; Littlewood, 2000). The significant factors affecting readiness for autonomy are as follows: learners' possession of decision- making abilities; learners' beliefs about their own roles and their teachers' roles; motivation; and the use of metacognitive learning strategies. Learners' possession of decisionmaking abilities enables them to participate in autonomous language learning. Holec (1981) claims that learners can make decisions in their learning by setting goals, choosing the content of their learning, and deciding which techniques to utilize. Nunan (1997) and Dickinson (1991) focus on the application of these decisions not only in the class but also beyond the classroom.

Learners' opinions about their roles and duties as well as their teachers' roles and responsibilities greatly affect the improvement of autonomy (Lamb, 2008). To illustrate, Cotterall's study (1995a.) concluded that 
learners who regarded teachers as facilitators had been more willing to learn autonomously than those who regarded teachers as authoritative figures. Although it is difficult for teachers to change their roles as suppliers of knowledge and controllers of the learning process into managers and facilitators of the learning process, Thanasoulas (2000), Zhou and Chen (2005) note that there are three steps which ensure this transfer: a) encouraging learners to identify their weaknesses, strengths, and needs in an independent way; b) promoting autonomous learning both in and out of the classroom so that learners may decide and work independently; and c) providing learners choices through the allotment of various tasks during learning.

Motivation is essential for affecting the manifestation of learner autonomy. Chan, Spratt and Humphreys (2002) support this idea by claiming that higher levels of motivation enable learners to participate more in autonomous learning activities outside the classroom. According to Dickinson (1995), learners' awareness of their responsibility for their learning depends on high motivation levels. Lee (1998) regards this interdependence as learners' voluntariness, a pre-requirement for learning language independently. Similarly, Littlewood (1996) uses interchangeably the terms "willingness," which is a significant component of autonomy in foreign language learning, and "motivation."

The improvement of learner autonomy is influenced by the usage of metacognitive learning strategies, also mentioned as regulatory skills or self-management strategies in research. By employing metacognitive strategies, learners can develop attitudes towards autonomous learning and regulate their own learning (Victori \& Lockhart, 1995). According to Zhou and Chen (2005, p.49), attitude means "meta-cognitive knowledge," which shapes new beliefs and values among learners; thus, learners may be inclined to seek new learning opportunities beyond the classroom in order to enhance their autonomy (Oxford, 1990).

One of the most significant aims of language education is to advance learner autonomy in English language classes. Researchers have conducted many studies on learner autonomy in language teaching (Benson, 2001; Deci, 1995; Dickinson, 1987; Kelly, 1996; Little, 1994, 2007). Still, there is a need to conduct more studies on refugee learners, who struggle to 
continue their education in countries in which languages and cultures are different from their own. No matter where learners are, they always have the potential to learn English. Moreover, creating an autonomous learning environment is possible anywhere as long as teachers and learners are aware of learners' potential for autonomous learning. Aside from enhancing their language learning, autonomy also enables learners to understand the world from different perspectives and change themselves, when necessary (Kenny, 1993). In conclusion, additional research is needed on the relationship between language learning and autonomy (Benson, 2001).

\section{Methodology}

\section{Participants}

Two hundred and fourteen Syrian students in the $6^{\text {th }}, 7^{\text {th }}$ and $8^{\text {th }}$ grades from Syrian refugee schools in Adana, Turkey, participated in the study. The schools functioned as four different temporary education centers (TEC) located in areas that had been quickly populated by immigrants living in low socio-economic conditions. Nine of the participants were from TEC1, 63 of them were from TEC2, 32 of them were from TEC3, and 110 of them were from TEC4. 46 of them were $6^{\text {th }}$ graders, 64 of them were $7^{\text {th }}$ graders, and 103 of them were $8^{\text {th }}$ graders. 136 students were female and 61 of them were male. The student participants' ages varied from 12 to 14 years, and their English levels were similar. They came from different cities in Syria; therefore, they differed in terms of background, socio-economic status, Arabic language proficiency, and standard of living. Eight Syrian English teachers from the TECs participated in the semi-structured interview component of this study. The teacher participants were also Syrian. There were two females and six males. The teachers had English-teaching certificates, $(\mathrm{N}=2)$, Bachelor's degrees $(\mathrm{N}=5)$, and Master's degree $(\mathrm{N}=1)$. They had 0-4 years of experience $(\mathrm{N}=2), 5-9$ years of experience $(\mathrm{N}=3), 10$ 14 years of experience $(\mathrm{N}=1), 15-19$ years of experience $(\mathrm{N}=1)$, and more than 20 years of experience $(\mathrm{N}=1)$ as English language teachers. They volunteered to contribute to the study by expressing their opinions about the results gathered by the quantitative data. 


\section{Data Collection Instruments}

The data were collected via both quantitative and qualitative instruments, and a mixed- method design was employed to investigate Syrian refugee EFL learners' perceptions about autonomy and their readiness for autonomy in language learning (Bozkurt \& Yalcin Arslan, 2017). Three questionnaires were administered: a) a questionnaire regarding participant demographics, b) Cotterall's (1995b.) Questionnaire about Language Learning Beliefs and Autonomy, and c) Nasöz's (2015) Learner Autonomy Readiness Questionnaire.

The first questionnaire dealt with the demographic information of the participants such as gender and grade, while the second and third questionnaire utilized a 5-point Likert scale ("strongly agree," "agree," "neither agree nor disagree," "disagree," "strongly disagree") in order to obtain learners' perceptions regarding autonomy in language learning and their readiness. Some questionnaire items were omitted because Cotterall (1995a.) states, "Only factor loadings of 0.43 and greater should be considered statistically significant (see Stevens, 1986, p. 344)." Consequently, variables having factor loadings of less than 0.43 were not included.

The scale of the second questionnaire, developed by (Cotterall, 1995a.), consisted of 17 items and 6 factors as follows: Role of Teacher, Role of Feedback, Learner Independence, Learner Confidence, Experience of Language Learning, and Approach to Studying. The second questionnaire investigating EFL learners' perceptions about autonomous language learning was analyzed according to four components of autonomy: motivation, students' views on their own roles and teachers' roles, decisionmaking abilities, and meta-cognitive strategy use. The scale of the third questionnaire, developed by Nasöz (2015), consisted of 31 items and investigated EFL learners' readiness for autonomous language learning.

Total scale reliabilities of the "Language Learning Beliefs and Autonomy" and "Learner Autonomy Readiness" questionnaires were measured using Cronbach alpha values. An $\propto$ of .83 and .89 were obtained for the two scales, respectively, satisfying the .70 criterion of Nunnally (1978). Before 
conducting the questionnaires of the study, they were translated from English to Arabic to enable the participants to understand the items more clearly as their native language was Arabic. After the initial translation was completed, the equivalence of the questionnaires' two versions was ensured by reverse translation which was made by two experts.

To support the results of the statistical data, eight Syrian English teachers and 33 students were interviewed and asked about the results of the research concerning the learners' perceptions about autonomy and their readiness for autonomy in language learning (Bozkurt \& Yalcin Arslan, 2017).

\section{Data Analysis}

Demographic questions were analyzed by utilizing descriptive statistics. One-way ANOVA and t-test were used to investigate if grade $\left(6^{\text {th }}, 7^{\text {th }}\right.$ and $\left.8^{\text {th }}\right)$ or gender had caused any significant differences in terms of Syrian refugee learners' perceptions of learner autonomy in language learning. A Pearson product-moment correlation was employed to investigate the significance of the relationship among perceptions of autonomy and readiness for autonomy.

Content analysis was used to examine the qualitative data, which was based on the ideas of the teachers and the students regarding the findings gathered from the semi-structured interviews. The transcribed raw data was then systematized to follow inductive content analysis steps. Thus, the content was initially coded and then themes were shaped around the emerging codes. In order to ensure the trustworthiness of this study, periodical help of a competent expert was taken for peer debriefing throughout the process of data analysis. To enable transferability thick description of the phenomenon was enriched by using quotes from the participants' responses in the result section. Lastly in order to provide interrater reliability, there was one more scorer except for the researcher (Fraenkel, Wallen \& Hyun, 2006). This section of data was also used to support the results of the statistical analyses. 


\section{Results and Discussion}

The findings and discussion of the research are presented under the following titles of each research question:

\section{The Role of Grade on Syrian Refugee EFL Learners' Perceptions of Learner Autonomy in Language Learning}

The first research question of the study sought to identify whether there were differences among grade levels $\left(6^{\text {th }}, 7^{\text {th }}\right.$ and $\left.8^{\text {th }}\right)$ in terms of Syrian refugee EFL learners' perceptions of learner autonomy in language learning. Table 1 below presents the mean scores of the participants' perceptions of autonomy in terms of grade (Bozkurt \& Yalcin Arslan, 2017).

Table 1

Means, Standards Deviations, and Sample Sizes for Grade on the Factors of the Questionnaire about Language-Learning Beliefs and Autonomy.

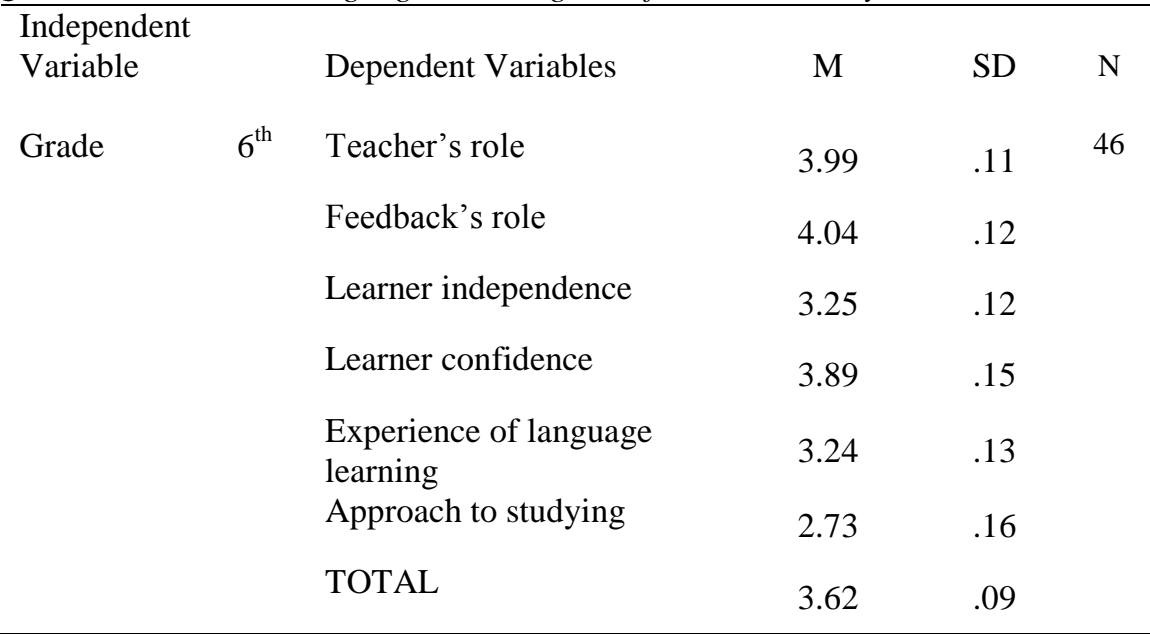


Table 1. Cont.

Means, Standards Deviations, and Sample Sizes for Grade on the Factors of the Questionnaire about Language-Learning Beliefs and Autonomy.

\begin{tabular}{|c|c|c|c|c|c|}
\hline \multicolumn{2}{|l|}{$\begin{array}{l}\text { Independent } \\
\text { Variable }\end{array}$} & Dependent Variables & M & SD & $\mathrm{N}$ \\
\hline \multirow{14}{*}{ Grade } & $7^{\text {th }}$ & Teacher's role & 3.85 & .12 & 63 \\
\hline & & Feedback's role & 3.87 & .11 & \\
\hline & & Learner independence & 3.26 & .11 & \\
\hline & & Learner confidence & 3.72 & .11 & \\
\hline & & $\begin{array}{l}\text { Experience of language } \\
\text { learning }\end{array}$ & 3.09 & .12 & \\
\hline & & Approach to studying & 3.02 & .14 & \\
\hline & & TOTAL & 3.55 & .08 & \\
\hline & $8^{\text {th }}$ & Teacher's role & 3.82 & .09 & 101 \\
\hline & & Feedback's role & 3.85 & .08 & \\
\hline & & Learner independence & 3.38 & .08 & \\
\hline & & Learner confidence & 3.84 & .10 & \\
\hline & & $\begin{array}{l}\text { Experience of language } \\
\text { learning }\end{array}$ & 3.58 & .09 & \\
\hline & & Approach to studying & 2.94 & .10 & \\
\hline & & TOTAL & 3.62 & .06 & \\
\hline
\end{tabular}

To have a more precise understanding of the difference and to obtain information about the role of grade on learners' perceptions, inferential analysis was employed alongside a One-Way ANOVA. Table 2 below summarizes the ANOVA findings for the effect of grade on each of the subscales. 
Table 2

Grade's Effect on Learners' Perceptions of Learner Autonomy

\begin{tabular}{llccc}
\hline $\begin{array}{l}\text { Independent } \\
\text { Variable }\end{array}$ & $\begin{array}{l}\text { Dependent } \\
\text { Variables }\end{array}$ & $\mathrm{F}$ & $\mathrm{P}$ & $\eta^{2}$ \\
\hline Grade & Teacher's role & .71 & .49 & .007 \\
& $\begin{array}{l}\text { Feedback's role } \\
\text { Learner }\end{array}$ & 1.02 & .36 & .010 \\
& $\begin{array}{l}\text { independence } \\
\text { Learner } \\
\text { confidence } \\
\begin{array}{l}\text { Experience of } \\
\text { language learning } \\
\text { Approach to }\end{array}\end{array}$ & .41 & .64 & .004 \\
studying & .98 & $.00 *$ & .004 \\
TOTAL & .32 & .72 & .053 \\
\hline
\end{tabular}

Note. *Difference is significant at $p<.05$

As seen in the table above, the results suggested that while grade did not affect refugee students' total perceptions in terms of autonomy, there was a significant difference among grades only in terms of refugee students' perceptions of experience of language learning. When Scheffe Post-Hoc analysis results were examined, the $8^{\text {th }}$ graders were observed to have perceived themselves as more experienced in language learning than the $6^{\text {th }}$ and $7^{\text {th }}$ graders $\left(8^{\text {th }}>6^{\text {th }}>7^{\text {th }}\right)$; nevertheless, no significant differences were observed among other levels or on other sub-scales.

Most of the interviewed students stated that there was a relationship between grade and autonomy in terms of experience in language learning. They indicated that as the $8^{\text {th }}$ grade students were older and more responsible, they had more experiences and information about the language and could better realize the importance of English. As individuals continue growing and developing simultaneously throughout life (Erikson, 1963; Ryff, 1995; Sheldon \& Kasser, 2001), the fact that older learners are seen as more equipped in terms of knowledge or experiences could be understood 
from the opinions of the students. According to Chadler and Connell (1987), older children have significantly more internalized analyses towards their tasks when compared with younger children. Furthermore, Sheldon, Kasser, Houser-Marko, Jones and Turban (2005) emphasized that chronological age can be essential to experiential autonomy.

Although the teachers also accepted the relation between grade and experience in language learning, they did not agree on the role of grade on the perceptions of the students and claimed that the students had similar perceptions towards learner autonomy in language learning. The reasons for the similarities in the perceptions of the students according to the teachers were learners' different life stages which could be observed from different perspectives such as cognitive, physical, and psychosocial development (Bastable \& Dart, 2008). Firstly most of the teachers claimed that the cognitive and psychological development of the students were similar due to their being members of a similar age group; therefore, it was normal for them to have similar perceptions of learner autonomy in language learning. According to Piaget's theory, there are stages in terms of cognitive development. The student participants of this study were at the beginning of the formal operations stage, a stage at which they are able to think critically or determine solutions to the problems they face (Huitt \& Hummel, 2003). Secondly, some of the teachers stated that regarding past experiences, present feelings, and circumstances, the learners' levels of well-being after the Syrian Crisis were so similar that they also had similar perceptions of learner autonomy in language learning. As chronological age is not the only indicator of the ability of an individual (Santrock, 2006; Vander Zandel, Crandell \& Crandell, 2007), the psychological development of the learners also results in their having similar perceptions of learner autonomy. Normative history-graded influences like wars or normative life events can be a turning point in an individual life (Santrock, 2006; Vander Zandel et. al, 2007). That is, there can be sharp differences in personal autonomy, especially during teenage years (Dornsbush, Erickson, Laird \& Wong, 2001; Bartle, Anderson \& Sabatelli, 1988).

Thirdly, one of the teachers interpreted differently the relation between grade and perception of learner autonomy in language learning by stating 
that "the relation can be between the learners' perceptions towards learner autonomy and the time of study no matter the grade". Learners' perceptions can be directed when they are aware of learning strategies because children have the capacity of eventually being autonomous when that capacity is nurtured by adults with whom they interact (Feinberg, 1980). Moreover, although all the student participants regarded learner autonomy in language learning similarly due to their similar past experiences, present feelings, and circumstances as a consequence of war, autonomy can be developed by means of relationships with both family and people outside the family (Purdie, Carrol \& Roche, 2004).

\section{The Role of Gender in Shaping Syrian Refugee EFL Learners' Perceptions of Learner Autonomy in Language Learning}

The role of gender in determining Syrian refugee EFL learners' perceptions of learner autonomy in language learning was investigated as the second research question of the study. Table 3 below presents the average scores of the participants' perceptions of autonomy in terms of gender.

Table 3

Means, Standards Deviations, and Sample Sizes for Gender on the Factors of the Questionnaire about Language Learning Beliefs and Autonomy

\begin{tabular}{|c|c|c|c|c|c|}
\hline $\begin{array}{l}\text { Independent } \\
\text { Variable }\end{array}$ & & Dependent Variables & M & SD & $\mathrm{N}$ \\
\hline \multirow[t]{7}{*}{ Gender } & \multirow[t]{7}{*}{ Female } & Teacher's role & 3.92 & .07 & \multirow[t]{7}{*}{136} \\
\hline & & Feedback's role & 3.94 & .06 & \\
\hline & & Learner independence & 3.40 & .07 & \\
\hline & & Learner confidence & 3.86 & .08 & \\
\hline & & $\begin{array}{l}\text { Experience of language } \\
\text { learning }\end{array}$ & 3.40 & .08 & \\
\hline & & Approach to studying & 2.93 & .09 & \\
\hline & & TOTAL & 3.64 & .05 & \\
\hline
\end{tabular}


Table 3 (Cont.)

Means, Standards Deviations, and Sample Sizes for Gender on the Factors of the Questionnaire about Language Learning Beliefs and Autonomy

\begin{tabular}{|c|c|c|c|c|}
\hline $\begin{array}{l}\text { Independent } \\
\text { Variable }\end{array}$ & Dependent Variables & M & SD & $\mathrm{N}$ \\
\hline \multirow{8}{*}{ Gender } & & & & \\
\hline & Teacher's role & 3.62 & .13 & 60 \\
\hline & Feedback's role & 3.69 & .14 & \\
\hline & $\begin{array}{l}\text { Learner } \\
\text { independence }\end{array}$ & 3.18 & .12 & \\
\hline & Learner confidence & 3.72 & .15 & \\
\hline & $\begin{array}{l}\text { Experience of } \\
\text { language learning }\end{array}$ & 3.28 & .12 & \\
\hline & $\begin{array}{l}\text { Approach to } \\
\text { studying }\end{array}$ & 2.87 & .13 & \\
\hline & TOTAL & 3.44 & .10 & \\
\hline
\end{tabular}

A t-test was used to obtain information regarding the role of gender on Syrian refugee EFL learners' perceptions of learner autonomy in language learning. Table 4 below summarizes the t-test findings for the effect of gender on each of the sub-scales.

Table 4

Gender's Effect on Learners' Perceptions of Learner Autonomy

\begin{tabular}{llcl}
\hline $\begin{array}{l}\text { Independent } \\
\text { Variable }\end{array}$ & Dependent Variables & $\mathrm{T}$ & $\mathrm{P}$ \\
\hline Gender & Teacher's role & 4.26 & $.04^{*}$ \\
& Feedback's role & 3.74 & $.05^{*}$ \\
& Learner independence & 1.71 & .11 \\
& Learner confidence & .77 & .37 \\
& Experience of language & .68 & .39 \\
& learning & & .03 \\
& Approach to studying & .03 & .08 \\
\hline
\end{tabular}

Note.* Difference is significant at $p<.05$ 
As Table 4 displays, the t-test results yielded a non-significant result pertaining to students' total perceptions; however, they revealed a significant effect of gender on both the teacher's role and feedback's role, but not on other sub-scales such as learner independence, learner confidence, experience of language learning, and approach to studying.

When the mean scores of males and females were calculated, the results indicated that female EFL learners' perceptions of learner autonomy were higher than those of their male counterparts in terms of the teacher's and feedback's role in language learning. That is, the male students depend more on the teacher's guidance and feedback compared to the females.

When the interviewed students expressed their opinions about the relationship between gender and autonomy, they generally said that their female friends were more eager to have responsibilities in learning English as they cooperated with their teachers more than their male friends $(n=19)$. Some of the students added that females were eager to learn English, yet males also could take responsibility for their learning when they possessed the required motivation. When interrogated regarding the possible reasons for male students' perceptions, teachers agreed on three reasons: a) compared with females, social pressure on males to address life challenges caused them to have less opportunity for autonomy in lessons $(n=6), b)$ females were more responsible and knowledgeable of language-learning strategies $(n=6), c)$ females could have more free time and opportunity to become autonomous $(n=4)$.

Although males develop autonomous behaviors more rapidly than females (Douvan \& Adelson, 1966; Coleman, 1961), cross-cultural differences can inversely affect their development of autonomy (Tung \& Dhillon, 2006). For instance, socialization is not the same for males and females. Whereas males are supported to be more autonomous, females are praised for their passivity. Then, males become more active in daily life and sometimes find themselves taking over family roles which are not appropriate for their ages. At the same time, females achieve psychosocial maturity and try to reduce their total dependency (Greenberger, 1984; Greenberger \& Sorenson, 1974). Then, females begin to resist their culturally structured identifications (Rind, 2015) and learning 
environments. Although, due to social norms, their actions are limited, they can have a chance to express themselves in the social environment of school. There, they can recognize that "education is a key indicator of women's status" (Al Riyami, Afifi \& Mabry, 2004) and succeed in performing better by cooperating with their teachers. For instance, a number of researchers (i.e. Ehrman \& Oxford, 1990; Oxford, 1993; Ellis, 1994) agree on the superiority of females in language development.

A good language learner is supposed to find strategies for coping with difficulties in the target language learning process (Rubin, 1975). According to Teacher Five, "female students use learning strategies much more than male students do," and many studies also highlight that females are better than males in terms of using language-learning strategies (Watanable, 1990; Green \& Oxford, 1995; Sy, 1994; Bacon \& Finnemann, 1992). As learning strategies enable learners to monitor their conscious methods of learning (Chamot, Barnhardt, El-Dinary \& Robbins, 1999), it can be concluded that females who use those strategies more frequently than males can take more responsibility for their learning and regulate the learning process successfully.

While applying learning strategies to control their learning progress, learners express their feelings about themselves, and their performance is influenced by internal perceptions (Fazey \& Fazey, 2001). They take more responsibility for their learning when they trust themselves and believe that they are "the control of the outcome" (Dickinson, 1995). In gender-based studies, females are likely to have more positive perceptions, higher motivation, and more awareness of learning strategies (Oxford, Nyikos \& Ehrman, 1988), so they take more responsibility and exert more effort in language learning (Salem, 2006). In this study, the quantitative results also demonstrated that the female students perceived themselves as being more autonomous in terms of the teacher's role and feedback's role; hence, they depended less on their teachers but still cooperated with them and took more responsibility for their learning. This means that having more positive attitudes or perceptions about themselves in language learning makes learners perform more autonomous. 


\section{The Relationship between Perceptions of Learning Autonomy and Readiness for Autonomy among Syrian Refugee EFL Learners}

The study also intended to identify whether there was a statistically significant relationship between the refugee EFL learners' perceptions of learner autonomy and their readiness for autonomy in language learning, and Table 5 presents the mean scores of the participants' perceptions of learner autonomy and their readiness for autonomy in language education.

Table 5

Means and Standards Deviations for Syrian Refugee EFL Learners' Perceptions of Learner Autonomy and Their Readiness for Autonomy in Language Learning

\begin{tabular}{lll}
\hline Variables & $\mathrm{M}$ & $\mathrm{SD}$ \\
\hline & & .58 \\
Readiness of autonomy & 3.68 & .63 \\
Perceptions for autonomy & 3.59 & \\
\hline
\end{tabular}

Note. $\mathrm{M}=$ mean $\mathrm{SD}=$ standard deviation

As Table 5 displays, descriptive results pointed out that students scored higher on Nasöz's Learner Autonomy Readiness Questionnaire (2015) than on Cotterall's Questionnaire about Language Learning Beliefs and Autonomy (1995). This indicated that Syrian refugee students' readiness for autonomy in English language learning was moderately high; and appeared to be higher than their perceptions of autonomous English learning scores.

A Pearson product-moment correlation was utilized to look at the relationship between Syrian refugee EFL learners' perceptions of learning autonomy and readiness for autonomy in language learning. Table 6 shows the size of the coefficient of correlation between perception of learning autonomy and readiness for autonomy for autonomy in Syrian refugee EFL learners. 
REMIE-Multidisciplinary Journal of Educational Research, 8(2) 133

Table 6

Relationship between Perception of Learning Autonomy and Readiness for Autonomy

\begin{tabular}{|c|c|c|c|}
\hline & & Readiness for autonomy & $\begin{array}{l}\text { Perception of learning } \\
\text { autonomy }\end{array}$ \\
\hline \multirow{2}{*}{$\begin{array}{l}\text { Readiness } \\
\text { for autonomy }\end{array}$} & Pearson & 1 & $.702^{*}$ \\
\hline & Sig. (2-tailed) & & .000 \\
\hline \multirow{3}{*}{$\begin{array}{l}\text { Perception of } \\
\text { learning } \\
\text { autonomy }\end{array}$} & Pearson & $.702^{*}$ & 1 \\
\hline & Correlation & & \\
\hline & Sig. (2-tailed) & .000 & \\
\hline
\end{tabular}

Note. *Correlation is significant at the 0.01 level (2-tailed) $\quad \mathrm{N}=214$

According to Table 6 , the results revealed a significant correlation coefficient with $\mathrm{r}=.70, \mathrm{p}=.00(\mathrm{p}<.05)$. That is, Syrian refugee students' perceptions of and readiness for English language learning were strongly related to one another; suggesting that when students' perceptions of autonomy increased, their readiness for autonomy also increased. This implies that when students' perceptions of autonomy increase, their readiness for autonomy also increases (Bozkurt \& Yalcin Arslan, 2017).

The findings above are similar to those of Cotterall's (1995), Gan's (2004), Yildirim's (2008), and Orawiwatnakul and Wichadee's (2017) studies, which also demonstrated a positive relationship to exist between language-learning behaviors and beliefs about language- learning autonomy. Learners who have high perceptions of autonomy behave more autonomously in learning (Orawiwatnakul \& Wichadee, 2017). When they have a higher sense of autonomy, they can also monitor their own learning more frequently (D’Ailly, 2003). In other words, positive perceptions of autonomy can provoke autonomous behaviors. Ushioda (2011), Chan, Spratt and Humphreys (2002) exemplified the relationship between perceptions of autonomy and readiness for autonomy by stating that learners could engage in autonomous behaviors when motivated. This means when they have positive perceptions about learning, they become better prepared to behave autonomously. From a different point of view, Dörnyei and Csizér (1998) described the correlation. In their study, they 


\section{Bozkurt \& Yalcin Arslan - Refugee EFL Learners' Autonomy}

stated that autonomy caused motivation. When motivation is regarded positively, it can be said that higher levels of readiness for autonomous behaviors also result in higher perceptions of autonomy. That is, as it is also claimed in this study, readiness for autonomy and perceptions of autonomy significantly impact each other.

The teacher participants agreed that their students' perceptions were slightly lower than their readiness for autonomy and provided the following reasons for this difference: a) physically and psychologically bad circumstances $(n=4), b)$ a lack of materials in the learning process $(n=3)$, c) a lack of knowledge and ability in the target language $(n=3)$, and d) their not being native speaker $(n=2)$. The teachers highlighted both the physically and psychologically bad circumstances which their students faced after the war, and they stated that the students had been affected by those circumstances so much that their perceptions of themselves as autonomous and their readiness for autonomous learning differed from each other. The teachers' opinions were based on the relationship between well-being and autonomy. Ryff explains this relation by stating that psychological wellbeing is an aspect of autonomy, goals in life, personal development, selfacceptance, and an individual's good relationship with others (1989, cited in Harrington \& Loffredo, 2007). With a sense of psychological security, learners can improve themselves more and better prepare themselves for real life (İlin \& Dişlen, 2014). Young people who have emotional wellbeing are more likely to succeed in their lives as they can set their goals, achieve them, take responsibility in making decisions, offer solutions to their problems, and have effective communications (Page \& Page, 2003). That is, they can develop the characteristics of an autonomous individual. Reflecting well-being in classrooms with positive learning environments, students can be more motivated and feel more confident, and their anxiety which otherwise hinders their learning may decrease (İlin \& Dişlen, 2014). When they have more positive self-perceptions and perceptions about learning content, students become more active in learning by trusting themselves to take responsibility for their learning and can gradually develop autonomy.

According to the teacher participants, a lack of materials in education also may hinder the readiness of students to become autonomous. As both 
the learner and the learning environment are always changing (Dent-Read \& Zukow-Goldring, 1997), the materials in the learning environment should be active and needs-based. The fact that obtaining knowledge outside the classroom has become easier and more popular by means of technological development contributes greatly to the development of autonomy (Gremmo \& Riley, 1995). Numerous materials to promote autonomy can be used for learners during the language-teaching process. That is to say, formal teaching can naturally promote learner autonomy when it is carefully designed and implemented (Ellis \& Sinclair, 1989).

Some of the teachers expressed that the learners were not much aware of their roles in their learning processes or learning strategies for demonstrating their potential autonomy. Their opinions were based on the importance of language awareness. When learners have awareness, they can decide on their goals, plans, activities, and learning strategies; then, they can control their own progress and become active in their learning processes (Holec, 1981).

The teachers also explained that not being native speakers of the language, the students had difficulties in becoming autonomous learners. Although it is possible to say that a non-native speaker can achieve nativelike competence (Calvino, 2011), language learners should be aware that language learning is a process. When learners experience the target language more extensively, they may become more capable of observing the language and developing strategies for controlling their learning.

In conclusion, the teacher participants implied that their students felt ready for autonomy; however, they needed more support in strengthening their perceptions of autonomy. If students are ready to engage in independent learning, then they should be given the opportunity and encouraged to perceive themselves as being capable of monitoring their learning.

The finding that both students' perceptions of autonomy and their readiness for autonomy were high is consistent with the findings of Altunay and Bayat (2009) and Ünal (2015). Since students have positive perceptions of autonomy, this means that they perceive themselves as capable of performing as autonomous learners. Thus, they endeavor to take responsibility for their language learning. In parallel with the study of 
Koçak (2003), students also feel ready to behave autonomously. On the other hand, the present study's finding regarding the fact that the learners' readiness for autonomy was higher than their perceptions of autonomy is not consistent with the findings of Ylldirım (2008). He supports that their perceptions of learner autonomy are related to their readiness, explaining that when learners are aware of the necessity to take responsibility for their learning, they use their abilities to do so. Thus, this conflicting result can contribute to and potentially complicate existing studies about learner autonomy.

\section{Conclusion and Suggestions for Further Research}

This study investigated the effects of grade and gender on students' perceptions of autonomy as well as the relationship between students' perceptions of autonomy and their readiness for autonomy. Moreover, teachers' and students' opinions about these relationships were taken into consideration. The findings revealed that learners' perceptions about autonomy and their readiness to take autonomous actions were related to each other. The students needed to be supported and encouraged. When the reasons behind their negative ideas about autonomy were eliminated, they would probably perceive themselves as being more autonomous. In conclusion, this study implies that teachers' awareness of learner autonomy could enable them to give their students the required skills knowledge and encourage them in an autonomous language-learning process. Their perceptions likely would increase alongside their readiness for autonomy, as there was a correlation between their perceptions and their readiness.

Most importantly, this study suggests that students' perceptions and readiness for autonomy in language learning should be examined in advance of an effective autonomous language- learning process, as their potential for autonomy can be affected both positively and negatively by their beliefs (Cotterall, 1995a.). Refugee learners, in particular, need to be understood before the commencement of their language-learning in different countries whose cultures and educational system are new to them. When learners become more aware of themselves and teachers become 
more aware of their students, they can commence a more efficient learning process and overall integration into a given educational system.

\section{Acknowledgements}

This article was generated from the MA thesis written by the first and supervised by the second author.

\section{References}

Al Riyami A., Afifi, M., \& Mabry R.M. (2004). Women's autonomy, education and employment in Oman and their influence on contraceptive use. Reprod Health Matters, 12(23), 144-54.

Altunay, U. \& Bayat, Ö. (2009). The relationship between autonomy perception and classroom behaviors of English language learners. Journal of Language, 144, 125-134.

Bacon, S. \& Finnemann, M. (1992). Sex differences in self-reported beliefs about foreign language learning and authentic oral and written input. Language Learning, 42, 471-495. doi.10.1111/j.14671770.1992.tb01041.x

Barfield, A., Ashwell, T., Carroll, M., Collins, K., Cowie, N., Critchley, M., \& Robertson, M. C. (2001). Exploring and defining teacher autonomy: A collaborative discussion. In A. S. Mackenzie and E. McCafferty (Eds.), Developing autonomy, proceedings of the college and university educators' 2001 conference, Shizuoka, japan (pp. 21722). Tokyo: The Japan Association for Language Teaching. Retrieved from http://www.encounters.jp/mike/professional/publications/tchauto.htm 1

Bartle, S. B.; Anderson, S. A. \& Sabatelli, R. M. (1988). A model of parenting style, adolescent individuation, and adolescent self-esteem: Preliminary findings. Journal of Adolescent Research, 4, 283-289.

Bastable S, B \& Dart M, A. (2007). Developmental stages of learner. In S. Bastable (Ed.), Nurse as educator (pp.147-198). Boston: Jones \& Barlett. 
Benson, P. (2001). Teaching and researching autonomy in language learning. London: Longman.

Benson, P. (2009). Making sense of autonomy in language learning. In R. Pemberton, S. Toogood, and A. Barfield (Eds.), Maintaining control: autonomy and language learning (pp. 13-26). Hong Kong: Hong Kong University Press. doi.10.5790/hongkong/9789622099234.003.0002

Bozkurt, N. \& Yalcin Arslan, F. (2017). The relationship between the Syrian refugee EFL learners' perceptions about learner autonomy and their readiness for autonomy in language learning, presented at 19th World Academy of Science, Engineering and Technology Conference, Berlin, 2017.

Calvino, M. A. M. (2011). Is it Possible to Achieve Native-Like Competence in Second Language Acquisition? Tlatemoani, 5.

Chamot, A. U., Barnhardt, S., El-Dinary, P.B. \& Robbins, J. (1999). The learning strategies handbook. White Plains, NY: Longman.

Chan, V., Spratt, M., \& Humphreys, G. (2002). Autonomous language learning: Hong Kong tertiary students' attitudes and behaviors. Evaluation \& Research in Education, 16(1), 1-18. doi.10.1080/09500790208667003

Chandler, C. L., \& Connell, J. P. (1987). Children's intrinsic, extrinsic and internalized motivation: A developmental study of children's reasons for liked and disliked behaviors. British Journal of Developmental Psychology, 5, 357-365.

Coleman, J. (1961). The adolescents society. Glencoe, IL: Free Press. Cotterall, S. (1995a). Developing a course strategy for learner autonomy. English Language Teaching Journal, 49(3), 219-227. doi.10.1093/elt/49.3.219

Cotterall, S. (1995b). Readiness for autonomy: Investigating learner beliefs. System, 23(2), 195-205. doi.10.1016/0346-251X(95)00008-8 D'ailly, H. (2003). Children's autonomy and perceived control in learning: A model ofmotivation and achievement in Taiwan. Journal of Educational Psychology, 95(1), 84-96. doi.10.1037/00220663.95.1.84 
Deci, E. (1995). Why we do what we do: The dynamics of personal autonomy. New York, NY: G.P. Putnam's Sons.

Dent-Read, C. \& Zukow-Goldring, P. (1997). Introduction: ecological realism, dynamic systems, and epigenetic systems approaches to development. In C. Dent-Read and P. Zukow-Goldring (Eds.), Evolving explanations of development: ecological approaches to organism-environment systems (pp. 1-22). Washington, DC:

American Psychological Association.

Dickinson, L. (1987). Self-instruction in language learning. Cambridge, UK: Cambridge University Press.

Dickinson, L. (1991). Self-instruction in language learning. Cambridge: Cambridge University Press.

Dickinson, L. (1995). Autonomy and motivation a literature review. System, 23(2), 165-174. doi.10.1016/0346-251X(95)00005-5

Dornbusch, M.S., Erickson, K. G., Laird, J., \& Wong C. A. (2001). The relation of family and school attachment to adolescent deviance in diverse groups and communities. Journal of Adoloscent Research, 16(4), 396-422.

Dörnyei, Z., \& Csizér, K. (1998). Ten commandments for motivating language learners: results of an empirical study. Language Teaching Research, 2(3), 203-29.

Douvan, E., \& Adelson, J. (1966). The adolescent experience. New York: Wiley.

Ehrman, M. E., \& Oxford, R. L. (1990). Adult learning styles and strategies in an intensive raining setting. The Modern Language Journal, 74, 311-326.

Ellis, G. \& B. Sinclair (1989). Learning to learn English: a course in learner training. Teacher's book. Cambridge: Cambridge University Press.

Erikson, E. (1963). Childhood and society. New York: Norton.

Fazey, D., \& Fazey, J. (2001). The potential for autonomy in learning. Studies in Higher Education, 26 (3), 345-361. doi.10.1080/03075070120076309 
Feinberg, J. (1980). The child's right to an open future. In W. Aiken and H. La Follette (Eds.). Whose child? Children's rights, parental authority and the state, Totowa, New Jersey: Rowman \& Littlefield.

Fong, R. (2004). Overview of immigrant and refugee children and families. In R. Fong (Ed.), Culturally competent practice with immigrants and refugee children and families (pp. 1-18). New York: Guilfor Press.

Fraenkel, J., Wallen, N. E., \& Hyun, H.H. (2006). How to design and evaluate research in education.(6th ed.). New York: McGraw Hill.

Gan, Z. (2004). Attitudes and strategies as predictors of self-directed language learning in an EFL context. International Journal of Applied Linguistics, 14(3), 389-411. doi.10.1111/j.1473-

4192.2004.00071.x

Green, J. M., \& Oxford, R. L. (1995). A closer look at learning strategies, L2 proficiency and gender. TESOL Quarterly, 29(2), 261-297. doi.10.2307/3587625

Greenberger, E. (1984). Defining psychosocial maturity in adolescence. In. P. Kaoly and J. Steffen (Eds.), Adolescent Behavior Disorders: Foundations and Contemporary Concern (pp. 54- 81). Lexington, MA: Heath.

Greenberger, E., \& Sorenson, A. (1974). Toward a concept of psychosocial maturity, Journal of Youth and Adolescence, 3, 329-358.

Gremmo, M. \& Riley, P. (1995). Autonomy, self-direction and self-access in language teaching and learning: the history of an idea. System, 23(2), 151-164.

Harrington, R. \& Loffredo, D. A. (2007). Private self-consciousness factors and psychological well-being, Journal of Psychiatry, Psychology and Mental Health, 1(1). Retrieved August 16, 2009 from http://www.scientificjournals.org/journals2007/articles/1086.htm

Holec, H. (1981). Autonomy in foreign language learning. Oxford: Pergamon Press.

Horwitz, E.K. (1987). Surveying student beliefs about language learning. In A. Wenden \& J. Rubin (Eds.), Learner strategies in language learning (pp. 119-129). Englewood Cliffs, NY: Prentice Hall. 
Huitt, W., \& Hummel, J. (2003). Piaget"s theory of cognitive development. Retrieved from http://chiron.valdosta.edu/whuitt/col/cogsys/piaget.html

İlin, G. \& Dişlen Dağgöl, G. (2014). Students' and teachers' stance towards learner autonomy and the psychological well-being within the ELT framework. International Journal of Languages' Education and Teaching, 2 (1), 92-108.

Karabiy1k, A. (2008). The Relationship between culture of learning and Turkish preparatory students' readiness for learner autonomy (Unpublished master's thesis). Bilkent University, Ankara, Turkey. Kelly, R. (1996). Language counseling for learner autonomy: The skilled helper in self-access language learning. In R. Pemberton, E. S. L. Li, W. W. F. Or and H. D. Pierson (Eds.), Taking control: Autonomy in language learning (pp. 93-114). Hong Kong: Hong Kong University Press.

Kenny, B. (1993). For more autonomy. System, 21(4), 431-442.

Koçak, A. (2003). A study on learners' readiness for autonomous learning of English as a foreign language (Unpublished master's dissertation). Middle East Technical University, Ankara, Turkey.

Lamb, T. (2008). Learner autonomy and teacher autonomy. In T. Lamb and H. Reinders (Eds.), Learner and teacher autonomy: Concepts, realities and responses (pp. 269-281). Amsterdam: John Benjamins.

Lee, I. (1998). Supporting greater autonomy in language learning. ELT Journal. 53(4), 282-290.

Little, D. (1994). Learner autonomy: A theoretical construct and its practical application. Die Neueren Sprachen, 93(5), 430-442. Little, D. (1996). Freedom to learn and compulsion to interact. In R., Pemberton, R., E.S.L Li, W.W.F Or and H. D. Pierson, (Eds), Taking control: autonomy in language learning. Hong Kong: Hong Kong University Press.

Little, D. (2007). Language learning autonomy: Some fundamental considerations revisited. Innovation in Language Learning and Teaching, 1(1), 14-29.

Littlewood, W. (1996). Autonomyll: An anatomy and a framework. System, 24(4), 427-435. doi.10.1016/S0346-251X(96)00039-5 
Littlewood W. (2000). Do Asian students really want to listen and obey? ELT Journal, 54(1), 31-36.

Nasöz, M. (2015). Turkish EFL learners' readiness for autonomy and attitudes toward self- access center. M.S. thesis. İhsan Doğramac1 Bilkent University.

Norton, B. (2000). Identity and language learning: gender, ethnicity and educational change. Harlow: Longman.

Nunan, D. (1989). The learner-centred curriculum. Cambridge: Cambridge University Press.

Nunan D. (1997). Designing and adapting materials to encourage learner autonomy. In P. Benson and P. Voller (Eds.), Autonomy and independence in language learning (pp. 192-203). London: Longman.

Nunnally, J. C. (1978). Psychometric theory (2nd ed.). New York: McGraw-Hill.

Orawiwatnakul, W. \& Wichadee, S. (2017). An Investigation of Undergraduate Students' Beliefs about Autonomous Language Learning. International Journal of Instruction, 10(1).

Oxford, R. (1990). Language learning strategies: What every teacher should know. Boston: Heinle \& Heinle Publisher.

Oxford, R. L. (1993). Gender differences in styles and strategies for language learning: What do they mean? Should we pay attention? In J. Alatis (Ed.), Strategic interaction and language acquisition: theory, practice, and research (pp. 541-557). Washington, DC: Georgetown University Press.

Oxford, R. L., Nyikos, M. \& Ehrman, M. E. (1988). Vive la différence? Reflections on sex differences in use of language learning strategies. Foreign Language Annals, 21 (4), 321-329. doi.10.1111/j.19449720.1988.tb01076.x

Page, R. M. \& Page, T. S. (2003). Fostering emotional well-being in the classroom. Sudbury, MA: Jones and Bartlett Publishers.

Purdie, N.; Carrol, A. \& Roche, L. (2004). Parenting and Adolescent SelfRegulation. Journal of Adolescence, 27, 663-676.

doi.10.1016/j.adolescence.2004.01.002 
Quinn, J.T. (1974). Theoretical foundations in linguistics and fields.

Responding to New Realities. . ACTFL Review of Foreign Language Education, $5,25 \mathrm{p}$.

Rind, I. A. (2015). Gender Identities and Female Students' Learning Experiences in Studying English as Second Language at a Pakistani University. Cogent Education, 2(1), 1-11. doi.10.1080/2331186X.2015.1115574

Rubin, J. (1975). What the 'good language learner' can teach us. TESOL Quarterly, 9, 41-51.

Ryff, C. D. (1995). Psychological well-being in adult life. Current Directions in Psychological Science, 4, 99-104.

Salem, Nada. M. (2006). The role of motivation, gender and language learning strategies in EFL (Unpublished master's dissertation). American University of Beirut.

Santrock, J. W. (2006). Life-span development (10th ed.). Boston: McGraw- Hill.

Sheldon, K. M. \& Kasser, T. (2001). Getting older, getting better? Personal strivings and psychological maturity across the lifespan.

Developmental Psychology, 37, 491-501.

Sheldon, M. K., Kasser, T., Houser-Marko, L., Jones, T. \& Turban, D. (2005). Doing One's Duty: Chronological Age, Felt Autonomy, and Subjective Well-Being. European Journal of Personality Eur. J. Pers., 19, 97-115.

Stevens, J. (1986) Applied Multivariate Statistics for the Social Sciences. Hillsdale, New Jersey: Lawrence Erlbaum Associates.

Sy, B. M. (1994). Sex differences and language learning strategies. Paper presented at the 11th Conference of Teachers of English to Speakers of Other Languages of the Republic of China, Taiwan.

Thanasoulas, D. (2000). What is learner autonomy and how can it be fostered? The Internet TESL Journal, Vol. VI, No. 11, November 2000. Retrieved from http://iteslj.org/

Tung, S., \& Dhillon, R. (2006). Emotional autonomy in relation to family environment: A gender perspective. Journal of the Indian Academy of Applied Psychology, 32(3), 201-212. 
Ushioda, E. (2011). Why autonomy? Insights from motivation theory and research. Innovation in Language Learning and Teaching, 5(2), 221232.

Ünal, S. (2015). (Mis)Match Between Teacher-Learner Autonomy

Perceptions and Its Relationship with EFL Learners' Achievement in Language Learning. (Published Master's Thesis). Yeditepe University, Istanbul.

Vander Zandel, J. W., Crandell, T. L. \& Crandell, C. H. (2007). Human development $\left(8^{\text {th }}\right.$ ed.). Boston: McGraw- Hill.

Victori, M., \& Lockhart, W. (1995). Enhancing metacognition in selfdirected language learning. System, 23(2), 223-234.

Watanabe, Y. (1990). External variables affecting language learning strategies of Japanese EFL learners: Effects of entrance examination, years spent at college/university, and staying overseas (Unpublished master's dissertation). Lancaster University, Lancaster, England.

Yıldırım, O. (2008). Turkish EFL learners' readiness for learner autonomy. Journal of Language and Linguistic Studies, 4, 65-80.

Zhou, Q. \& Chen, S. (2005). The mode of promoting learner autonomy for non-English majors through classroom instruction. US-China Education Review, 11(2), 46-52.

Zou, X. (2011). What happens in different contexts and how to do learner autonomy better? Teacher Development: An International Journal of Teachers' Professional Development, 15(4), 421-433. 
REMIE-Multidisciplinary Journal of Educational Research, 8(2) 145

Nilcan Bozkurt is a teacher at the Ministry of Education in Adana, Turkey.

Fadime Yalcin Arslan is an assistant professor at English Language Teaching Department, Faculty of Education, Gaziantep University in Gaziantep, Turkey.

\section{https://orcid.org/0000-0003-0644-5636}

Contact Address: Fadime Yalcin Arslan. English Language Teaching Department, Faculty of Education, Gaziantep University, 27310, Gaziantep / Turkey.

E-mail: fyalcin80@gmail.com 


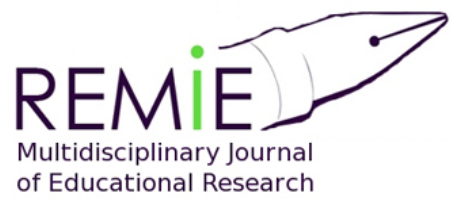

Instructions for authors, subscriptions and further details:

http://remie.hipatiapress.com

\section{Iranian EFL Teachers' Emotional Intelligence and their Use of Speaking Strategies}

Karim Shabani ${ }^{1}$ Arezu Ghodrati ${ }^{1}$

1) Allameh Mohaddes Nouri University, Islamic Republic of Iran

Date of publication: June $15^{\text {th }}, 2018$

Edition period: June 2018-October 2018

To cite this article: Shabani, K. \& Ghodrati, A. (2018). Iranian EFL Teachers' Emotional Intelligence and their Use of Speaking Strategies. Multidisciplinary Journal of Educational Research, 8(2), 146-179. doi: 10.17583/remie.2018.3450

To link this article: http://dx.doi.org/10.17583/remie.2018.3450

PLEASE SCROLL DOWN FOR ARTICLE

The terms and conditions of use are related to the Open Journal System and to Creative Commons Attribution License (CC-BY). 


\section{Iranian EFL Teachers' Emotional Intelligence and their Use of Speaking Strategies}

Karim Shabani

Allameh Mohaddes Nouri

University
Arezu Ghodrati

Allameh Mohaddes Nouri

University

\section{Abstract}

The study was designed to investigate the differences among Iranian EFL teachers in terms of emotional intelligence (EI) and their use of speaking strategies. To this end, 90 EFL male and female teachers teaching English at 9 institutes in Behshahr, Sari, and Amol cities in Mazandaran Province (north of Iran) were randomly selected. The research data were collected through the Bar-On EQ-I scale and teachers' use of speaking strategies questionnaire. Results on Independent Sample ttest reported significant differences in teachers' EI across gender. One-way ANOVA revealed differences in teachers' EI across years of teaching experience. Furthermore, results on Kruskal Wallis Test indicated differences in teachers' use of each speaking strategy regarding their level of EI. Based on the findings, teachers with a higher level of EI preferred to focus on both accuracy and fluency and apply story-telling activities to create more successful interaction. While teachers with a lower level of EI preferred to focus on accuracy, they liked to apply information-gap activities. They preferred to offer implicit feedback through reformulation and tended to design groups and pairs to make silent students interact in the classroom. Moreover, both groups preferred to correct their learners later.

Keywords: teachers' emotional intelligence (EI), feedback, speaking strategies 


\section{Inteligencia Emocional de Maestros de EFL Iraníes y su Uso de Estrategias de Habla}

Karim Shabani

Allameh Mohaddes Nouri

University
Arezu Ghodrati

Allameh Mohaddes Nouri

University

\section{Resumen}

El estudio investiga las diferencias entre los profesores de EFL iraníes en términos de inteligencia emocional (EI) y su uso de estrategias de oratoria. Con este fin, se seleccionó aleatoriamente a 90 profesores y maestras de EFL que enseñaban inglés en 9 institutos en las ciudades de Behshahr, Sari y Amol en la provincia de Mazandaran (norte de Irán). Los datos de la investigación se recopilaron a través de la escala Bar-On EQ-I y el cuestionario de estrategias de uso del docente. Los resultados de la prueba $\mathrm{t}$ de muestras independientes informaron diferencias significativas en la IE de los docentes en todos los géneros. ANOVA de un factor reveló diferencias en EI de docentes a través de años de experiencia docente. Además, los resultados en la prueba de Kruskal-Wallis indicaron diferencias en el uso por parte de los docentes de cada estrategia de habla con respecto a su nivel de EI. Con base en los hallazgos, los maestros con un mayor nivel de EI prefirieron enfocarse tanto en la precisión como en la fluidez y aplicar actividades de narración de historias para crear una interacción más exitosa. Profesores con un nivel más bajo de IE prefirieron centrarse en la precisión, aplicando actividades de brecha de información. Preferían ofrecer retroalimentación implícita a través de la reformulación y tendían a diseñar grupos y pares para hacer que los estudiantes silenciosos interactuaran en el aula. Además, ambos grupos prefirieron corregir a sus alumnos más tarde.

Palabras clave: graduate education, science, scientific literacy, STS 
$\mathrm{P}$ revious studies suggest that teachers make a difference in the lives of students both academically and personally. According to Veen et al. (2005, cited in Thoonen et al., 2011) teachers' personal and psychological factors are the key elements affecting their teaching and learning. One approach to exploring the emotional practice of teaching involves understanding the "emotional intelligence" (EI) performed by teachers at work. EI was described by Bar-On (2002) as "an array of noncognitive capabilities, competencies, and skills that influence one's ability to succeed in coping with environmental demands and pressures" (p.14). It is considered to be more powerful than IQ in predicting success in life challenges, in distinguishing successful people within job categories or profession (Goleman, 1995). Teachers' emotional skills have recently received considerable research interest in the field of education and psychology. Previous researches demonstrated that emotional intelligence is associated with success in many areas, including effective teaching (Ghanizadeh \& Moafian, 2010), student learning (Brackett \& Mayer, 2003), and academic performance (Gil-Olarte, Palomera, \& Brackett, 2006). With this information at hand, the context of foreign language teaching with regard to the personality factors of EFL teachers remains challengeable and needs more practical study and investigation.

Among the four language skills, speaking is viewed to be the most important skill of all the four skills (listening, speaking, reading, and writing) because people who know a language are usually referred to as speakers of that language (Ur, 2005). Teachers play an essential role in the acquisition of this skill in that they are in charge of promoting meaningful communication in the classroom. As speaking is an important medium of providing input for learners of English, finding optimum ways of teaching speaking is a challenging task for EFL teachers and researchers. Since teachers are different in emotional intelligence and other personality traits, they may choose different speaking strategies. Being aware of such personality factors might help them select the best way of speaking strategies.

The present study was an attempt to investigate the differences in Iranian EFL teachers' EI and their use of speaking strategies. In order to explore the 
differences in these two constructs, it is necessary to review the related literature and the previous studies on the topic.

\section{Related Studies}

The related literature on EI and teaching speaking will be reviewed in the following sections.

\subsection{Emotional Intelligence}

1.1.1. Theoretical framework of emotional intelligence. Various theories exist under the term intelligence. The concept of social intelligence was born through attempts by Thorndike in 1920. He defined the term as the ability to understand men and women, boys and girls and to act wisely in human relations (Mayer \& Salovey, 1997). David Weschler (1940), the father of IQ (general intelligence), discussed the idea of there being nonintellective aspects to intelligence. Maslow (1950) describes how people can build emotional strength. Leuner (1966) was then the first individual to link EI to psychotherapy treatments. Howard Gardner (1983) published a study on multiple intelligences. His concepts of interpersonal intelligence (the ability to understand other individuals' emotions and intentions) and intrapersonal intelligence (the ability to know one's own emotions) are widely regarded as the basis for conceptualizing EI. Bar-On (1985) coined the term 'Emotional Quotient' to describe his approach to assessing emotional intelligence. However, it was the work by Peter Salovey and Jack Mayer (1990) that produced the first theory on EI. The EI concept was then made popular through Daniel Goleman's book published in 1995.

According to Mayer and Salovey (1997), emotional intelligence consists of two parts as emotion and intelligence. Emotions refer to the feelingreactions a person has, often in response to a real or imagined relationship. For example, if a person has a good relationship with someone else, that individual is likely to feel happy; if the person is threatened, he or she will be likely to feel afraid. Intelligence, on the other hand, refers to the ability to reason validly with or about something. For example, one reason with 
language in the case of verbal intelligence, or reasons about how objects fit together in the case of spatial intelligence.

\subsubsection{Various views and definitions of Emotional Intelligence.} Salovey \& Mayer (1990, p. 189) defined the term EI as "a form of social intelligence that involves the ability to monitor one's own and others feelings and emotions to discriminate among them and use this information to guide one's thinking and action." They further propose that "Emotional intelligence involves the ability to perceive accurately, appraise, and express emotion; the ability to access and/or generate feelings when they facilitate thought; the ability to understand emotion and emotional knowledge; and the ability to regulate emotions to promote emotional and intellectual growth.” (Mayer \& Salovey, 1997, p. 10).

Bar-On (1997a, p. 14) defined EI "as an array of non-cognitive capabilities, competencies and skills that influence ones' abilities to succeed in coping with environmental demands and pressures". Goleman (1998) defined EI as the capacity to recognize our own feelings and those of others, for motivating ourselves, and for managing emotions well in ourselves and in our relationships.

1.1.3. Models of Emotional Intelligence. Roohani (2009) mentioned that emotional intelligence can be investigated in two ways: ability models and mixed models. Ability model refers to emotional intelligence as a pure form of mental ability and also as a pure intelligence. On the other hand, the proponents of mixed model expanded the meaning of EI by combining cognitive ability with personality traits.

Mayer and Salovey (1997) proposed an ability model with a two-part form, speaking first of the general processing of emotional information, and secondly specifying the skills involved in such processing (Motallebzadeh, 2009). The model comprises four abilities: perception, assimilation, understanding, and regulation of emotions. Concisely, emotional perception consists of the ability to perceive emotions on the self and on the others, and also on objects, art, stories, music, and other stimuli. The assimilation of emotions is the ability to generate, use, and feel emotions as necessary to communicate feelings, or to use them in other cognitive processes. 
Emotional understanding is related to the ability to understand emotional information, how emotions combine and shift across time, and the ability to appreciate emotional meanings. Finally, emotional regulation refers to the ability to stay open to feelings, and to monitor and regulate one's and other's emotions to promote understanding and personal growth. These four branches are hierarchically organized, thus, perceiving emotions is at the most basic level, and managing emotions is at the highest and most complex level in the hierarchy; therefore, the ability to regulate one's and other's emotions is built on the basis of the competencies of the three other branches.

Two mixed models of EI were introduced by Goleman and Bar-on. They defined emotional intelligence in a different way. Goleman (1998) described a mixed model in terms of performance, individual abilities and competencies, integrating personality trait and employing their similar effects on performance in the workplace. While Bar-On's (1985) model provided personality basis, emphasizing the co-dependence of the ability aspects of emotional intelligence with personality traits and their application to personal wellbeing (Nassimi, 2009).

Goleman (1998) stated that EI comprises five essential elements: 1) knowing one's emotions; 2) managing emotions; 3) motivating oneself; 4) recognizing emotions in others, and 5) handling relationships. But in 1998 his model presents 4 essential dimensions and 20 competencies (Goleman, 1998). First, self-awareness is the ability to be conscious and appreciate one's feelings and includes 3 competencies: emotional self-awareness, accurate self-management, and self-confidence. Second, self-Management is the ability to effectively manage one's emotions and comprises 6 competencies: self-control, trustworthiness, conscientiousness, adaptability, achievement drive and initiative. Third, social awareness is the ability to associate with and feel part of one's social group and includes 3 competencies: empathy, service orientation, and organizational awareness. Fourth, relationship management is the ability to appreciate and affect others' emotions and includes 8 competencies: developing others, influence, communication, conflict management, leadership, change catalyst, building bonds and teamwork and collaboration. 
Bar-On (1997b) coined the term 'emotional quotient' (EQ). Based on Bar-On's model of EI, EI is a combination of emotional and social skills that determine our understanding and expression of ourselves, our understanding for others and interaction with them, and the ability to deal with daily necessities and problems. His inventory measures 5 major scales and 15 subscales:

1) Intrapersonal skills refer to the ability to know and control one's emotions. It comprises emotional self-awareness (the ability to be aware, recognize and understand feelings and ideas in the self), assertiveness (the ability to express and defend beliefs and thoughts in the self), self-regard (the ability to understand, accept and respect of the self), self-actualization (the ability to realize one's potential), independence (the ability to be self-controlled and self-directed in ones thinking and free from emotional dependency).

2) Interpersonal skills refer to the ability to be aware of and understand feelings and ideas in the others. It involves empathy (the ability to understand how others feel and appreciate others feelings), interpersonal relationship (the ability to establish and maintain mutually satisfying relationships that are characterized by emotional closeness and intimacy and by giving and receiving affection), social responsibility (the ability to demonstrate oneself as a cooperative, constructive and responsible member of the society).

3) Adaptability is concerned with the ability to adjust to change. It includes reality-testing (the ability to assess between what is subjectively experienced and what objectively exists), problem solving (the ability to identify and solve the problem) and flexibility (the ability to adapt one's emotions and thoughts to change).

4) Stress management refers to manage and regulate emotions and control stress. It comprises stress tolerance (the ability to cope with stressful situations by managing emotions) and impulse control (the ability to delay a desire or temptation by controlling one's emotion). 
5) General mood is concerned with the ability to be optimistic and enjoy life. It includes happiness (the ability to be satisfied and enjoy life) and optimism (the ability to think positively and keep a positive attitude in the face of difficulties).

\subsection{Teaching Speaking}

Speaking is a productive oral skill which is the hardest skill to teach because it happens in real time (Nunan, 2003). Celce-Murcia (2003) argued that for most people "the ability to speak a language is synonymous with knowing that language since speech is the most basic means of human communication." (p.103). Learners' success in language learning is by their feeling about their progression in language proficiency. To achieve this goal, teachers and materials for teaching speaking must provide the strategies that are necessary for developing good speaking abilities.

1.2.1. Aspects of speaking. In teaching speaking skills, teachers should consider two aspects, namely fluency and accuracy. Therefore, when they teach speaking to their students, neither of these two elements should be neglected. The absence of either of these elements will create ambiguity and impatience on the part of the listener.

1.2.1.1. Fluency. Fluency usually refers to expressing the oral language freely without interruption. According to Hedge (2000, p. 261), fluency means responding coherently with the turns of the conversation, linking words and phrases using intelligible pronunciation and appropriate intonation, and doing all this without undue hesitation. To achieve this goal, the teachers should allow learners to use their personal language freely to express their own ideas without interruption.

1.2.1.2. Accuracy. Accuracy is the ability to produce grammatically correct sentences and it focuses on the correct use of grammar and vocabulary and other skills. Skehan (1996b, p.23 cited in Ellis \& Barkhuizen, 2005, p.139) defines accuracy as "how well the target language is produced in relation to the rule system of the target language." Therefore, 
learners should focus on a number of things in their production of the spoken language, mainly, the grammatical structure, vocabulary and pronunciation.

$>$ Pronunciation. As Redmond and Vrchota (2007, p.104) state, "It is imperative that you use the correct word in the correct instance and with the correct pronunciation. Pronunciation means to say words in ways that are generally accepted or understood." However, if the pronunciation is not correct, the speakers then will not be understood and therefore accuracy is not achieved. So, intelligibility is the most sensible goal in teaching pronunciation. Intelligibility has been defined as being understood by a listener at a given time in a given situation.

$>$ Grammar. Achieving accuracy in terms of grammar refers to the study of how words combine to form sentences (Nelson, 2001, p. 1). This is done by a set of rules or principles that can be used to generate all well-formed or grammatical utterances in the language (Purpura, 2004, p. 6).

Vocabulary.Vocabulary is a set of lexemes including single words, compound words and idioms (Richard \& Schmidt, 2002, p. 580). Accuracy in vocabulary use refers to the appropriate selection of words during speaking. The knowledge of the word classes also allows speakers to perform well-formed utterances (Harmer, 1991). Students then, have to be able to use words and expressions accurately. They sometimes use words incorrectly like in the case of synonyms which do not carry the same meaning in all contexts.

1.2.2. Speaking activities. A large number of speaking activities are used in the classroom in many circumstances. Among others, the examples of speaking activities are the discussion and debate, drama, role play, and simulation, presentation, classroom conversation, casual chat, outside-class speaking, storytelling, joke, and anecdote (Thornbury, 2005, pp. 89-110). 
Littlewood (1981, p. 47) states that "discussion provides learners with opportunities to express their own personality and experience through the foreign language". Drama, role play, and simulation activate students' imagination. Drama provides a useful springboard for real-life language use. Role-play gives students an opportunity to practice communicating in different social contexts and in different social roles. Presentation is a planned talk followed by a question session. Essberger (1998) suggests that participation could be accomplished by means of presentations. Classroom conversation is called a planned conversation to encourage the students to speak English. Outside-class speaking consists of tape diaries, video conferencing, and human-computer interaction. Storytelling is an effective tool in improving the oral competencies of students (Isbell, Sobol, Lindauer \& Lowrance, 2004). In information-gap activity, speakers have different parts of information making up a whole. Harmer (1998, p.88) argues that the teacher uses this kind of activities aiming at sharing information between students during a classroom oral course.

1.2.3. Teachers' feedback in speaking. Lynch (1996, p. 117) stated that the term feedback refers to any information that leads to the success of the message. Teachers need to help students to cope with errors by giving feedback. Feedback is a necessary element in teaching and is used throughout the lesson. Yet, the teachers may differ in using different correction strategies. According to Ellis (2008), direct or explicit feedback occurs when the teacher identifies an error and provides the correct form, while indirect or implicit feedback refers to situations when the teachers shows that an error has been made but does not provide a correction, thereby leaving the students to infer and correct it. The teachers should recognize how and when to correct their students' performance. If the teachers interrupt and correct whenever there is a problem, the conversational flow as well as the purpose of the speaking activity will be destroyed (Harmer, 2001). Group work is likely to promote collaboration among the learners, in which learners help each other and are encouraged to share their ideas and knowledge (Doff, 1991). 
1.2.4. Dealing with silent students. While speaking class demands active participation of the students, some of them are silent during the lesson. Teachers should consider the class situation and choose an appropriate way to make silent students interact in the classroom. As admitted by researchers, teachers can design pair/group work or they can choose interesting topics. Ur (1996, pp.5-6) claims that in order to get the pupils to communicate with each other and express themselves freely in the target language it is necessary to use interesting topics, but more importantly the discourse must have a meaningful purpose. Participation in communicative activities such as paired and small group activities would enhance meaningful and interesting interactions as well as provide more opportunities to speak (Scarcella \& Oxford, 1992).

\subsection{Studies on Emotional Intelligence and Teaching Speaking}

To confirm the relationship between EFL teachers' emotional intelligence and job satisfaction, Hekmatzadeh, Khojasteh and Shokrpour (2016) asked EFL teachers who work at private language institutes in Iran to complete the Bar-On questionnaire and a modified version of Karavas's (2010) job satisfaction scale. Subsequent to feeding the data into SPSS and running Pearson Product-Moment Correlations, these researchers found a positive and significant relationship between EFL teachers' emotional intelligence and job satisfaction. Furthermore, significant differences in emotional intelligence between EFL male and female teachers (but not a significant correlation between EFL teachers job satisfaction in terms of gender) were found.

Mousapour and Khorram (2015) found a significant correlation between Iranian EFL teachers' scores on emotional intelligence and teaching styles. The participants of this study were 90 Iranian EFL teachers from Sistan and Baluchestan's high schools and language institutes from whom the data were collected through the use of Bar-On Emotional Quotient questionnaire and Grasha's Teaching Styles Inventory questionnaire. It was found that among the five components of emotional intelligence, four components (interpersonal, intrapersonal, adaptability, and stress management) were positive predictors of teaching styles of EFL teachers. 
Upadhyaya (2013) examined the correlation between emotional intelligence and academic achievement among student-teachers. To assess the emotional intelligence of student-teachers, the participants were asked to complete the test of emotional intelligence of Misra. Collected data were matched with the student-teachers' marks in theory and practical examination. Based on the findings of the research, there was a positive correlation between student-teachers' emotional intelligence and academic achievement (theory and practice), i.e. the more emotionally intelligent they were the better they were found to score in theory and practical examination.

To explore the teaching of speaking in secondary education (SE) institutions and state language schools (EOI) in Spain, Alonso (2014) used a sample of all in-service teachers (from twelve secondary schools and two EOIs in Galicia) who were then administered a questionnaire focused on the time devoted to the teaching and practicing of spoken English, the assessment of speaking, the type of activities the participants used and frequency of their use. To analyze the data, a Wald-type test was run. Results of this exploratory study revealed that EOI teachers devote more time to the teaching and practice of speaking, focus more on pronunciation and interaction in the assessment of speaking, and prefer less-controlled tasks.

Anjaniputra (2013) conducted a research to identify teachers' strategies in teaching speaking to the students at the secondary level and recognize the students' response to the strategies. An English teacher and a class of 22 students involved in this study. To identify the strategies of teaching speaking, the researcher employed classroom observation and interview and to obtain the data about the students' response towards the strategies, a questionnaire was given to students. The findings indicated that the teacher applied cooperative activities, role-play, creative tasks, and drilling and the students had a positive attitude towards the strategies as they responded that the strategies helped them to speak. 


\section{The Present Study}

Following the model proposed by Bar-On (1985), the present study was intended, first, to determine the differences in teachers' EI across gender and years of teaching experience. Then, differences in teachers' use of each speaking strategies with respect to their level of EI were explored. Hence, the following research questions were raised:

1. Is there any significant difference among Iranian EFL teachers in terms of EI across gender?

2. Is there any significant difference among Iranian EFL teachers in terms of EI with respect to years of teaching experience?

3. Is there any significant difference among Iranian EFL teachers with different EIs in the use of speaking strategy?

\section{Methodology}

\subsection{Research Design}

The design of this study was a descriptive field study. Heppner, Kivlighan, and Wampold (1999) portray these studies as "investigations that do not exercise experimental control (randomization, manipulation of variables) and are conducted in a real life setting" (p.48). Due to the nature of the design, the present study was high in external validity since participants were directly recruited from the population of interest. All the participants were chosen randomly. In this research, teachers' EI served as an independent variable and their use of speaking strategies served as the dependent variable. 
REMIE - Multidisciplinary Journal of Educational Research, 8(2) 159

\subsection{Participants}

The present study was conducted with the participation of 90 (50 female and 40 male) EFL teachers with teaching experiences ranging from 1 to 15 years. Teachers held either BA $(n=56)$ or MA $(n=34)$ degrees. Besides, teachers ranged in age from 20 to 50 years. The summary of the participants' specifications is shown in tables 1 and 2 below.

Table 1:

\begin{tabular}{lll}
\multicolumn{3}{l}{ Distribution of subjects based on gender } \\
\hline Gender & Frequency & Percent \\
\hline Male & 40 & 44.4 \\
Female & 50 & 55.6 \\
\hline Total & 90 & 100.0 \\
\hline
\end{tabular}

Table 2.

Distribution of subjects based on years of experience

\begin{tabular}{ccc}
\hline $\begin{array}{c}\text { Years of } \\
\text { experience }\end{array}$ & Frequency & Percent \\
\hline $1-5$ & 29 & 32.2 \\
$6-10$ & 30 & 33.3 \\
$11-15$ & 31 & 34.4 \\
\hline Total & 90 & 100.0 \\
\hline
\end{tabular}

\subsection{Instrumentation}

To obtain the relevant data, the researcher employed two sets of instruments as follows: 

a. Bar-On EQ test (to measure the teachers' level of emotional intelligence)

b. Teachers' use of speaking strategies questionnaire (to get an understanding of the teachers' use of speaking strategies)

3.3.1. Bar-On EI test. Bar-On EI test is a self-report measure of emotionally and socially intelligent behavior that provides an estimate of emotional-social intelligence (Bar-On, 1985). It is also called the emotional quotient inventory (EQ-I) designed by Bar-On in 1980. Though the original version of the test included 133 items, later revisions were applied to the test by Bar-On himself (1985) who reduced its size to a considerable degree so that the modified version of the test comprised only 117 items. It is suitable for individuals with 17 years of age and older. To avoid cross-cultural differences and probable misunderstanding regarding the context of the questionnaire, the translated Persian version of this questionnaire was developed by Samouei (2002) and reduced into 90 items in the form of short sentences which measure five broad areas of skills and 15 factorial components (already explained in Bar-On's model). Each item employs a five point Likert scale with a textual response format ranging from strongly disagree (1) to strongly agree (5). The sum of all items comprises the total score being referred to as the EQ score. The minimum score is 270 and the maximum score is 450 . In the case that some items were negatively ordered they were scored reversely. It takes approximately 40 minutes to complete the Persian version of this questionnaire.

3.3.1.1. Reliability and validity of the $E Q-i$. Reliability relates to the extent to which an instrument accurately measures a phenomenon with different groups of participants at various times (Creswell, 1994). Validity relates to the extent to which an instrument measures what it is designed to measure (Creswell, 1994). The EQ-i was found to have sufficient validity in measuring EQ. Because the EQ-I is the first empirically constructed test of non-cognitive intelligence to be published, it can be used in research such as the present study with a reasonable certainty of obtaining meaningful results. 
The reliability of the EQ items has been demonstrated in several ways; for example, the Cronbach's alpha reliability index was reported as 0.80 (Samouei, 2003). In another study, the Persian version of the questionnaire had proven to have good internal consistency, test-retest reliability and construct validity by Dehshiri (2003). The Cronbach's alpha coefficient for this measure was found to be 0.76 . Moreover, the factor analysis provided some support for the inventory's hypothesized structure. The Persian version of the questionnaire which had been proven to be valid by Dehshiri (2003) was applied in this study. In the present study, the reliability of the questionnaire was computed through Cronbach's alpha. The results show an acceptable reliability index of 0.95 for the questionnaire. As for validation, exploratory factor analysis was run.

3.3.2. Teachers' use of speaking strategies questionnaire. To find out what speaking strategies are used by teachers in their teaching of English as a Foreign Language, the researcher used a questionnaire adapted from Khadidja (2010). In order to test the validity of questionnaire as a research instrument, and hence the reliability of the data to be obtained, the questionnaire was first piloted with 60 (30 females and 30 males) EFL teachers. They were chosen randomly. Upon receiving their suggestions, some items were eliminated and others introduced. The final questionnaire was composed of five items. Each item has one orientation.

The objective of the first item is to obtain information from teachers concerning the main speaking aspects they usually focus on in classroom interaction, i.e. fluency, accuracy or both because these are also the main objectives behind teaching speaking. The second item concerns the speaking activities (including: presentation, information-gap activities, role-play, story-telling, group/pair work, and discussion) teachers focus on most to create a successful interaction. The third item is designed to get teachers' opinion on when to correct the students' mistakes during the interaction activities. The options include whether teachers prefer to interrupt their students to correct them, correct them later, ask other students to correct each other, or do not correct them at all. The fourth item is designed to get teachers' opinion on whether they use implicit or explicit feedback in giving corrective feedback to students. The fifth item designed to get information 
about the teachers' decisions to push silent students to interact in the classroom on whether they prefer to design groups and pairs or choose interesting topics.

\subsection{Data Collection Procedure}

In order to achieve the purpose of the present study, the following two phases were considered. In the first phase, permission of authorities was obtained to collect the data. In the second phase, Bar-On EQ-i questionnaire (Bar-On, 1985) and teachers' use of speaking strategies scale were given (in person) to 90 EFL teachers teaching English at 9 institutes in Behshahr, Sari and Amol cities in Mazandaran province (North of Iran). They were selected on the basis of random sampling. The purpose of the study was explained to them. The researchers assured them that the collected information would be kept confidential and used just for research purposes. Teachers took the questionnaires home, filled them out, and then returned them the following session.

\subsection{Data Analysis}

After collecting the data, EQ questionnaires were first scored based on the guidelines provided by Bar-On (1985). Then, EFL teachers' EI scores were divided into two categories of high $(n=45)$ and low $(n=45)$ by means of the software SPSS (to find the differences in teachers' EI and their use of speaking strategies).

According to the research questions mentioned before, the following statistical analyses were run using SPSS 0.23.

Independent samples t-test was run to find the differences in teachers' EI across gender. To compare two groups (for example, men and women), we computed the t-test (Dornyei, 2007)

One-way ANOVA was used to explore the differences in teachers' EI across years of teaching experience. According to Dornyei (2007), the analysis of variance (ANOVA) can be used to compare more than two groups. 
Kruskal Wallis test was run to find out the differences in teachers' use of each speaking strategy regarding their level of EI. As Dornyei (2007) states, Kruskal Wallis test is the non-parametric alternative to one-way ANOVA.

In the current study:

Runs Test was used to show that the data were selected randomly.

Levene's Test was run to indicate the equality of variances.

Shapiro-Wilk goodness-of-fit test was calculated to report the normality distribution of the data.

\section{RESULTS}

Based on the analyzed data the following results are presented to answer the research questions.

\subsection{Findings Obtained for Research Question One}

Q1: Is there any significant difference among Iranian EFL teachers in terms of EI across gender?

In order to show the differences in teachers' EI across gender, Independent samples t-test was computed.

4.1.1. The assumption for random data collection. Run test was conducted to show that the data were collected randomly. As shown in Table 3, p-values are not more than .05 for two constructs (EI and speaking strategies). So it can be concluded that the data were collected randomly and the first assumption was met. 
Table 3.

Results on Runs Test of Total EQ and speaking strategies

\begin{tabular}{ccc}
\hline & Total EQ & Total speaking \\
\hline Test Value $^{\text {a }}$ & 337.00 & 11.00 \\
Cases $<$ Test Value & 45 & 37 \\
Cases $>$ = Test Value & 45 & 53 \\
Total Cases & 90 & 90 \\
Number of Runs & 2 & 30 \\
Z & -9.329 & -3.193 \\
Asymp. Sig. (2-tailed) & .000 & .001 \\
\hline a. Median & & \\
\hline
\end{tabular}

4.1.2. The assumption for normality distribution. The results of Shapiro-wilk goodness-of-fit test showed that the total EI scores were normal in distribution $(\mathrm{p}=.85>.05$ and $\mathrm{p}=.180>.05)$. Therefore, the results of independent samples t-test were examined to find the significance of the difference (see Table 4).

Table 4.

Results on the Tests of Normality of teachers' EI across gender

\begin{tabular}{ccccc}
\hline & Gender & \multicolumn{3}{c}{ Shapiro-Wilk } \\
\cline { 3 - 5 } & & Statistic & Df & Sig. \\
\hline Total & Male & .951 & 40 & .085 \\
EQ & Female & .967 & 50 & .180 \\
\hline
\end{tabular}




\subsubsection{The assumption for equality of variances and results on} Independent sample t-test.As can be seen in Table 5, the variance came out to be homogeneous $(\mathrm{p}=.875>.05)$. In addition, according to the results obtained from independent-samples t-test of total EI scores for both males and females, there was a significant difference in teachers' EI across gender.

Results on Independent Samples t-test for differences in teachers' EI across gender

\begin{tabular}{|c|c|c|c|c|c|c|c|c|c|c|}
\hline & & \multicolumn{2}{|c|}{$\begin{array}{c}\text { Levene's Test for } \\
\text { Equality of } \\
\text { Variances } \\
\end{array}$} & \multicolumn{7}{|c|}{ t-test for Equality of Means } \\
\hline & & \multirow[t]{2}{*}{$\mathrm{F}$} & \multirow[t]{2}{*}{ Sig. } & \multirow[t]{2}{*}{$\mathrm{t}$} & \multirow[t]{2}{*}{$\mathrm{df}$} & \multirow{2}{*}{$\begin{array}{c}\text { Sig. } \\
(2- \\
\text { tailed }) \\
\end{array}$} & \multirow[t]{2}{*}{$\begin{array}{c}\text { Mean } \\
\text { Difference }\end{array}$} & \multirow{2}{*}{$\begin{array}{c}\text { Std. Error } \\
\text { Differenc } \\
\mathrm{e} \\
\end{array}$} & \multicolumn{2}{|c|}{$\begin{array}{l}95 \% \text { Confidence Interval of the } \\
\text { Difference }\end{array}$} \\
\hline & & & & & & & & & Lower & Upper \\
\hline \multirow[t]{2}{*}{ TotalEQ } & $\begin{array}{c}\text { Equal variances } \\
\text { assumed }\end{array}$ & .025 & .875 & -8.350 & 88 & .000 & -44.99500 & 5.38872 & -55.70394 & -34.28606 \\
\hline & $\begin{array}{c}\text { Equal variances } \\
\text { not assumed }\end{array}$ & & & -8.484 & 87,392 & .000 & -44.99500 & 5.30379 & -55.53620 & $-34,45380$ \\
\hline
\end{tabular}

4.1.4. Group statistics of teachers' EI across gender. The results of group statistics showed that females obtained a higher mean score than males which indicated that females are higher in EI level than males (see Table 6). 
Table 6.

Results on the group Statistics of teachers' EI across gender

\begin{tabular}{cccccc} 
& gender & $\mathrm{N}$ & Mean & Std. Deviation & Std. Error \\
& & & & Mean \\
\hline Total & male & 40 & 312.0250 & 23.35181 & 3.69225 \\
EQ & female & 50 & 357.0200 & 26.92354 & 3.80756 \\
\hline
\end{tabular}

\subsection{Findings Obtained for Research Question Two}

Q2: Is there any significant difference among Iranian EFL teachers in terms of EI with respect to years of teaching experience?

To answer this question, One-way ANOVA was run.

4.2.1. The assumption for normality distribution. The results of Shapiro-Wilk goodness-of-fit test showed that all the total EI scores were normal in distribution (see Table 7). Therefore, One-way ANOVA was used to find the differences in EFL teachers' EI across years of teaching experience. 
REMIE - Multidisciplinary Journal of Educational Research, 8(2) 167

Tabela 7.

Results on the Tests of Normality of differences in teachers' EI across years of teaching experience.

\begin{tabular}{ccccc}
\hline & $\begin{array}{c}\text { Years of teaching } \\
\text { experience }\end{array}$ & Statistic & Df & Sig. \\
\cline { 3 - 5 } & $1-5$ & .955 & 29 & .241 \\
Total & $6-10$ & .975 & 30 & .686 \\
EQ & $11-15$ & .952 & 31 & .178 \\
& & & & \\
\hline
\end{tabular}

4.2.2. The assumption for equality of variances. The results of the Levene's test (Table 8$)$ showed a significant $p$-value $(p=.725>.05)$ which showed that the assumption of equal variances was met.

Table 8.

Results on the test of homogeneity of variances of differences in teachers' EI across years of teaching experience

\begin{tabular}{cccc}
\hline Levene Statistic & \multicolumn{3}{c}{ Total EQ } \\
\cline { 2 - 4 } & df1 & df2 & Sig. \\
\hline .323 & 2 & 87 & .725 \\
\hline
\end{tabular}

4.2.3. One-way ANOVA Test: ANOVA table (Table 9) demonstrated significant statistical differences in teachers' EI across years of teaching experience $(.000<.05)$. 
Table 9.

ANOVA of differences in teachers' EI across years of teaching experience

\begin{tabular}{cccccc}
\hline & & \multicolumn{5}{c}{ Total EQ } \\
\cline { 2 - 6 } & Sum of Squares & Df & Mean Square & F & Sig. \\
\hline Between Groups & 31234.254 & 2 & 15617.127 & 19.261 & .000 \\
Within Groups & 70541.702 & 87 & 810.824 & \\
Total & 101775.956 & 89 & & \\
\hline
\end{tabular}

\subsection{Findings Obtained for Research Question Three.}

Q3: Is there any significant difference among Iranian EFL teachers with different EIs in the use of speaking strategies?

4.3.1. Inferential statistics of Kruskal-Wallis Test. Kruskal-Wallis Test was used to find if the two groups (teachers with high and low EI) were statistically different in their use of speaking strategies. The results revealed significant differences between the high- $(n=45)$ and low-EI $(n=45)$ EFL teachers in item $1(\mathrm{X} 2(1)=34.65, \mathrm{n}=90, \mathrm{p}=.000)$, item $2(\mathrm{X} 2(1)=11.62$, $\mathrm{n}=90, \mathrm{p}=.001)$, item $4(\mathrm{X} 2(1)=19.77, \mathrm{n}=90, \mathrm{p}=.000)$, and item $5(\mathrm{X} 2(1)=$ $13.11, \mathrm{n}=90, \mathrm{p}=.000)$. However, the two groups were similar in item 3 for which no significant differences were seen $(X 2(1)=2.64, n=90, p=.104)$ (see Table 10). 
REMIE - Multidisciplinary Journal of Educational Research, 8(2) 169

Table 10.

Results of the test statistics $a, b$ of differences in teachers' use of each speaking strategies regarding their level of EI

\begin{tabular}{lccccc}
\hline & Item 1 & Item 2 & Item 3 & Item 4 & Item 5 \\
\hline Chi-Square & 34.659 & 11.620 & 2.645 & 19.778 & 13.116 \\
df & 1 & 1 & 1 & 1 & 1 \\
Asymp. Sig. & .000 & .001 & .104 & .000 & .000 \\
a. Kruskal & & & & & \\
Wallis Test & & & & \\
b. Grouping & & & & \\
Variable: Total & & & & \\
EI & & & & & \\
\hline
\end{tabular}

4.3.2. Descriptive statistics of Kruskal-Wallis Test. The descriptive statistics for the first item showed a higher mean score for high-EI $(\mathrm{M}=2.57$, $\mathrm{Md}=3.00, \mathrm{SD}=.543)$ than the low-EI EFL teachers $(\mathrm{M}=1.55, \mathrm{Md}=1.00$, $\mathrm{SD}=.724$ ) indicating that the high-EI teachers tend to focus on both fluency and accuracy while the low-EI teachers tend to focus on accuracy during the classroom interaction (see Table 11).

The results of the second item showed, once more, a higher mean score for the high-EI teachers $(\mathrm{M}=4.24, \mathrm{Md}=4.00, \mathrm{SD}=1.28)$ than for their lowEI counterparts $(M=3.02, M d=2.00, S D=1.75)$ (see Table 11). It can, thus, be shown that the teachers with high EI mostly focus on story-telling activities while those with low EI focus on information-gap activities to create a successful interaction.

The results of the third item showed, however, that the teachers with low EI $(\mathrm{M}=2.15, \mathrm{Md}=2.00, \mathrm{SD}=1.24)$ had an almost as high mean score as those with high $\mathrm{EI}(\mathrm{M}=2.44, \mathrm{Md}=2.00, \mathrm{SD}=.72)$ (see Table 11). It can, therefore, be stated that both groups of teachers, equally, preferred to correct the learners' errors later.

The results of the fourth item also showed that both groups had almost similar mean scores although low-EI teachers $(\mathrm{M}=1.55, \mathrm{Md}=2.00, \mathrm{SD}=$ 
.50) had slightly higher mean than the high-EI ones $(M=1.11, M d=1.00$, $\mathrm{SD}=.31$ ) (see Table 11). The results, however, showed opposite findings. That is, the teachers with low EI tend to offer implicit corrective feedback through reformulation while the teachers with high EI tend to offer explicit corrective feedback and tell the learners about the form.

The results of the fifth item showed that the two groups were rather similar. However, the high-EI group $(\mathrm{M}=1.77, \mathrm{Md}=2.00, \mathrm{SD}=.42)$ had a bit higher mean score than the low-EI group $(\mathrm{M}=1.40, \mathrm{Md}=1.00, \mathrm{SD}=.49)$ suggesting that the teachers with high EI tended more to choose interesting topics while those with low EI tended to design groups and pairs (see Table 11).

Table 11.

Results on the Descriptive Statistics of differences in teachers' use of each speaking strategy regarding their level of EI

Percentiles

N Mean $\quad$ Std. Deviation $\quad$ Minimum $\quad$ Maximum $\quad 25^{\text {th }} \quad$ 50th (Median)

\begin{tabular}{|c|c|c|c|c|c|c|c|c|c|}
\hline \multirow{6}{*}{ High } & Item 1 & 45 & 2.5778 & .54309 & 1.00 & 3.00 & 2.0000 & 3.0000 & 3.0000 \\
\hline & Item2 & 45 & 4.2444 & 1.28197 & 2.00 & 6.00 & 3.0000 & 4.0000 & 6.0000 \\
\hline & Item 3 & 45 & 2.4444 & .72474 & 1.00 & 4.00 & 2.0000 & 2.0000 & 3.0000 \\
\hline & Item4 & 45 & 1.1111 & .31782 & 1.00 & 2.00 & 1.0000 & 1.0000 & 1.0000 \\
\hline & Item5 & 45 & 1.7778 & .42044 & 1.00 & 2.00 & 2.0000 & 2.0000 & 2.0000 \\
\hline & EQ & 45 & 1.0000 & .00000 & 1.00 & 1.00 & 1.0000 & 1.0000 & 1.0000 \\
\hline \multirow{6}{*}{ LOW } & Item 1 & 45 & 1.5556 & .72474 & 1.00 & 3.00 & 1.0000 & 1.0000 & 2.0000 \\
\hline & Item2 & 45 & 3.0222 & 1.75148 & 1.00 & 6.00 & 1.0000 & 2.0000 & 5.0000 \\
\hline & Item 3 & 45 & 2.1556 & 1.24235 & 1.00 & 4.00 & 1.0000 & 2.0000 & 3.0000 \\
\hline & Item 4 & 45 & 1.5556 & .50252 & 1.00 & 2.00 & 1.0000 & 2.0000 & 2.0000 \\
\hline & Item5 & 45 & 1.4000 & .49543 & 1.00 & 2.00 & 1.0000 & 1.0000 & 2.0000 \\
\hline & EQ & 45 & 2.0000 & .00000 & 2.00 & 2.00 & 2.0000 & 2.0000 & 2.0000 \\
\hline
\end{tabular}


See de Figure 1.

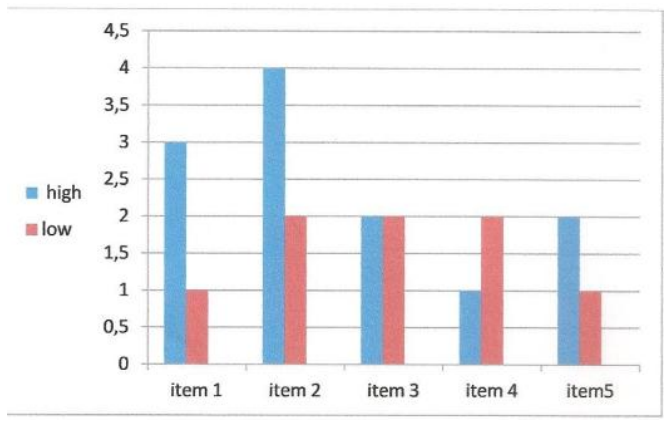

Figure 1

The median difference for the speaking scores of the teachers with high- and low-EI

\section{Discussion}

After analyzing the obtained results, a number of important points are worth mentioning. First, there were significant differences in teachers' EI across gender and years of teaching experience. It was shown that females had a higher level of EI than males and teachers with more years of teaching experience had a higher level of EI as well. Based on these results, the null hypotheses were rejected. Second, it was revealed that teachers with higher and lower EI differed from one another in their use of speaking strategies in items 1, 2, 4 and 5. As two groups were similar in item 3, no significant differences were seen. So the null hypothesis was rejected for all items, except for item 3 . In simple terms, the following outcomes were obtained for each group of teachers.

Group1: EFL teachers with a higher level of EI preferred to focus on both accuracy and fluency. To improve the students speaking skills, teachers should combine fluency and accuracy. They selected to apply story-telling activities to create more successful interaction. Moreover, using story-telling more emotionally intelligent teachers change the class room environment 
from a dry boring one to a warm environment full of students' concentration, participation and production. As Mallan (1992) reported storytelling helps develop the imagination which in turn builds on problemsolving competencies. The more teachers know about storytelling, the better they will be able to teach and model it for their students. Actually, storytelling technique attracts student's attention and higher concentration. This technique provokes prediction and expectation of events. Consequently, those effects lead to deeper comprehension, enjoyment and happiness. They tended to employ explicit corrective feedback through the expression of their opinions on the form of the mistakes and they tended to choose interesting topics to make silent learners interact in the classroom. To do this, the teacher has to think first about what is interesting for the learners rather than to him/her.

Group 2: EFL teachers with a lower level of EI preferred to focus on accuracy and they liked to apply information-gap activities. They preferred to offer implicit feedback through reformulation and they tended to design groups and pairs to make silent learners interact in the classroom.

Moreover, both groups preferred to correct their learners later and this is in line with what Harmer (1991) who stated that when students do communicative activities teachers should not interrupt them to point out a grammatical, lexical, or pronunciation error, because it can stop the communication.

The findings of the study are consistent with Ghanizadeh and Moafian (2010), and Vaezi and Fallah (2011) studies, where they found significant differences in teachers' EI across years of teaching experience. The result of the current study is in line with Hekmatzadeh, Khojasteh and Shokrpour (2016), where they reported significant differences in teachers' EI across gender.

The current study was limited to Iranian EFL teachers, not other countries with English as their EFL programs. 


\section{Conclusion}

In the present research the differences in Iranian EFL teachers' EI and their use of speaking strategies were investigated. This study provided some insights into the differences in EI as conceptualized by the Bar-On (1985) and EFL teachers' use of speaking strategies. It can be concluded that teachers' emotional intelligence is a vital concept in our era of educational climate reform. Teachers with a higher level of EI are more successful in using speaking strategies. Since emotions can be regarded as the mediators between sensory input and thinking, having a high emotional quotient may help teachers be better providers of input and they may consequently choose appropriate strategies in speaking tasks.

\section{Implications}

\subsection{Theoretical Implication}

According to Mayer \& Salovey (1997), EI is expected to be involved in the home, in school, in work, and other settings. More emotionally intelligent individuals might succeed at making their workers feel better, at communicating in interesting ways, and at designing projects that involve infusing products with feelings and aesthetics. Particularly useful, we believe, is the natural emotional teaching that comes with many of the liberal arts and with various value systems as well.

\subsection{Pedagogical Implication}

Education authorities and teacher trainers will benefit from the findings of this study to consider EI in promoting teachers with more successful teaching strategies. Language teachers will be provided with the rationale to carry out suggested strategies in class to improve students' speaking skills. 


\section{Suggestions}

Based on the obtained findings, further research is needed to replicate and expand the findings of this study by increasing the number of participants and using other instruments such as case study and interview. The following topics are worth of investigation:

- Effective ways to improve teachers' EI in EFL classrooms.

- The role of other psychological factors (e.g. personality factors or teachers' sense of self-efficacy) on EFL teachers' use of speaking strategies.

- Differences in EFL teachers' EI and their use of other English skills (listening, reading, and writing).

- The effect of explicit/ implicit corrective feedback on accuracy and fluency of Iranian EFL learners' oral production.

- The use of story-telling to improve teaching speaking in Iranian EFL context.

- The role of choosing interesting topics to make silent students interact in the classroom.

\section{References}

Alonso, R. (2014). Teaching Speaking: an Exploratory Study in Two Academic Contexts. Porta Linguarum, 22, 145-160. Retrieved from http://www.ugr.es/ portalin/articulos/PL_numero22/10\%20\%20ROSA\%2 OALONSO.pdf

Anjaniputra, A. G. (2013). Teacher's strategies in teaching speaking to students at secondary level. Journal of English and Education, [S.l.], 1(2), 1-8. Retrieved from: http://ejournal.upi.edu/index.php/LE/article/view/577 . 
Bar-On, R. (1985). The development of an operational concept of psychological well-being. Unpublished doctoral dissertation (first draft). Rhodes University, South Africa.

Bar-On, R. (1997a). The Emotional Quotient Inventory (EQ-i): A test of emotional intelligence. Toronto: Multi-Health Systems.

Bar-On, R. (1997b). Bar-On Emotional Quotient Inventory (EQ-i): Technical manual. Toronto: Multi-Health Systems.

Bar-On, R. (2002). Bar-On Emotional Quotient Inventory: Short Technical Manual. Toronto. Canada: Multi-Health Systems.

Brackett, M. A., \& Mayer, J. D. (2003). Convergent, discriminate, and incremental validity of competing measures of emotional intelligence.

Personality and Social Psychology Bulletin, 29(9), 1147-1158.

Celce-Murcia, M. (ed). (2003). Teaching English as a Second or Foreign Language (3rd Ed). Boston, MA: Heinle \& Heinle.

Creswell, J. W. (1994). Research Design: Qualitative and Quantitative Approaches. Thousand Oaks, CA: Sage.

Dehshiri, R. (2003). The Reliability and Validity of EQ-i in Iran's Context. Unpublished Master's Thesis. Allame Tabataba'i University, Tehran, Iran. Doff, A. (1991). Teach English: A Training Course for Teachers. New York: Cambridge University Press.

Dornyei, Z. (2007). Research Methods in Applied Linguistics. New York: Oxford University Press.

Ellis, R. (2008). The Study of Second Language Acquisition (2nd ed). Oxford: Oxford University Press.

Ellis, R. \& Barkhuizen, G. (2005). Analyzing Learner Language. Oxford: Oxford University Press.

Essberger, J. (1998). English speaking practice through presentation. Retrieved April, 2009 from www.englishclub.com/tefl-articles/englishspeaking-practice presentations.htm/

Gardner, H. (1983). Multiple Intelligences: The Theory in Practice. New York: Basic Books Inc.

Ghanizadeh, A., \& Moafian, F. (2010). The role of EFL teachers' emotional intelligence in their success. ELT Journal, 64(4), 424-435. doi.10.1093/elt/ccp084 
Gil-Olarte P, Palomera R, Brackett M (2006). Relating emotional intelligence to social competence and academic achievement in high school students. Psicothema, 18(suppl), 118-123. Retrieved from

http://www.psicothema.com/pdf/3286.pdf

Goleman, D. (1995). Emotional Intelligence: why it can Matter more than $I Q$. New York: Bantom Books.

Goleman, D. (1998). Working with Emotional Intelligence. New York: Bantam Books.

Harmer J. (1991). The Practice of English Language Teaching. New York: Longman Publishing.

Harmer, J. (1998). How to Teach English. Pearson Education: Longman. Harmer, J. (2001). The Practice of English Language Teaching. Harlow: Pearson Education Ltd.

Hedge, T. (2000). Teaching and Learning in the Language Classroom. Oxford: Oxford University Press.

Hekmatzadeh, M.H., Khojasteh, L. \& Shokrpour, N. (2016). Are Emotionally Intelligent EFL Teachers More Satisfied Professionally? International Journal of Applied Linguistics \& English Literature. 5(2), 97-107. doi: 10.7575 /aiac.ijalel.v.5n.2p.97

Heppner, P. P., Kivlighan, D. M., \& Wampold, B. E. (1999). Research Design in Intelligence: Kingsvillle Intelligence. Toronto, ON: MultiHealth Systems Inc.

Isbell, R., Sobol, J., Lindauer, L, \& Lowrance, A. (2004). The Effects of Storytelling and Story Reading on the Oral Language Complexity and Story Comprehension of Young Children. Early Childhood Education Journal, 32(3), 157-163. doi:10.1023.94189.a3

Karavas, E. (2010). How satisfied are Greek EFL Teachers with their Work? Investigating the Motivation and Job Satisfaction Levels of Greek EFL Teachers. Porta Linguarum, 14, 59-78.

Khadidja, K. (2010). The effect of classroom interaction on developing the learners' speaking skill. The case of third-year LMD students of English at Constantine University. Unpublished thesis. Constantine University.

Leuner, B. (1966). Emotional intelligence and emancipation. Praxis Kinderpsychol. Kinderpsychiatrie 15, 193-203. 
Littlewood, W. (1981). Communicative Language Teaching: An Introduction. New York: press syndicate of the University of Cambridge. Lynch, T. (1996). Communication in the Language Classroom. Oxford: Oxford University Press.

Mallan, K. (1992). Children as Storytellers. Portsmouth: Heinemann Educational Books, Inc.

Maslow, A. (1950). Social Theory of Motivation. Inshore, M, (Ed), Twentieth-century mental Hygiene. New-York: Social sciences publishers, 347- 357.

Mayer, J.D. \& Salovey, P. (1997). What is emotional intelligence? In P. Salovey \& D. Sluyter (Eds.). Emotional development and emotional intelligence: educational applications (pp. 3-31). New York: Basic Books.

Motallebzadeh K. (2009). The relationship between the emotional intelligence of Iranian EFL learners and their reading comprehension and structural ability. Journal of Teaching English as a Foreign Language and Literature, 1(4), 39-55.

Mousapour, G. \& Khorram, A. (2015). The relationship between Iranian EFL teachers' emotional intelligence and their teaching styles. International Journal of Research Studies in Language Learning, 4, 3-14.

Nelson, G. (2001). English an Essential Grammar. London and New York: Routledge.

Nunan, D. (ed.) (2003). Practical English language teaching. New York: McGraw-Hill. Press.

Purpura, J. (2004). Assessing Grammar. Cambridge: Cambridge University Press.

Redmond, M.V. \& Vrchota, D. (2007). Everyday Public Speaking. England: Pearson Education.

Richard, J.C. \& Schmidt, R. (Eds.). (2002). Longman Dictionary of Language. New York: Routledge.

Roohani, A. (2009). The study of emotional intelligence and literature in education; Gender and major of study. The Journal of Asian TEFL, 6(4), 33-69.

Salovey, P. \& Mayer, J.D. (1990). Emotional intelligence. Imagination, Cognition and Personality, 9, 185-211. 
Samouei, R. (2002). Interpreting and analyzing Bar-On EQ inventory. Journal of Sina Research Center, 6(2), 1-10.

Samouei, R. (2003). Azmoune houshe hayajani (Bar-On's EQ-i). Tehran:

Moasseseye Tahghighatie Olume Raftarie Sina.

Scarcella, R. C., \& Oxford, R. L. (1992). The Tapestry of Language

Learning: The Individual in the Communicative Classroom (63p.).

Boston, MA: Heinle \& Heinle.

Thoonen, E., Sleegers, P., Oort, F., Peetsma, T., \& Geijsel, F. (2011). How to improve teaching practices: the role of teacher motivation, organizational factors, and leadership practices. Educational Administration Quarterly, 47(3), 496-536. doi.10.1177/0013161X11400185

Thornbury, S. (2005). How to Teach Speaking. New York: Longman. Upadhyaya, P. (2013). A Study of the Relationship between Emotional Intelligence and Academic Achievement among Student- Teachers. European Academic Research, 1(8), 2388- 2396. Retrieved from http://euacademic.org/uploadarticle/173.pdf

Ur, P. (1996). A Course in Language Teaching: Practice and Theory. Cambridge: Cambridge.

Ur, P. (2005). Discussions that Work. Cambridge: Cambridge University Press.

Vaezi, Sh. \& Fallah, N. (2011). The relationship between Emotional Intelligence and Burnout among Iranian EFL Teachers. Journal of Language Teaching and Research, 2(5), 1122-1129.

doi:10.4304/jltr.2.5.1122-11298

Wechsler, D. (1940). Nonintellective factors in general intelligence.

Psychological Bulletin, 37, 444-445. 
REMIE - Multidisciplinary Journal of Educational Research, 8(2) 179

Karim Shabani is an assistant professor at English Department of Allameh Mohaddes Nouri University. Islamic Republic of Iran. https://orcid.org/0000-0002-1574-1122

Arezu Ghodrati is an MA graduate of TEFL at English Department of Allameh Mohaddes Nouri University. Islamic Republic of Iran.

Contact Address: Allameh Mohaddes Nouri University, Sheikh Fazlollah Nouri Street, 46418-59558. Islamic Republic of Iran

Phone: +989113954613

E-mail: k.shabani@mohaddes.ac.ir or shabanikarim@gmail.com 


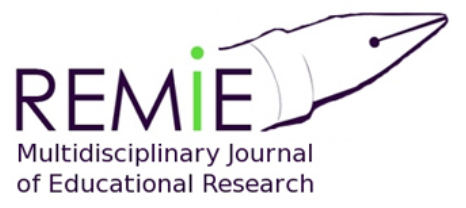

Instructions for authors, subscriptions and further details:

http://remie.hipatiapress.com

\section{International Theatrical Educational Programs: Moscow Art Theatre School Experience}

Elena Viktorovna Burdenko ${ }^{1}$, Irina Artsis ${ }^{2}$, Natalia llyushchenko ${ }^{2}$

1) Plekhanov Russian University of Economics, Russian Federation

2) Moscow Art Theatre School, Russian Federation

Date of publication: June $15^{\text {th }}, 2018$

Edition period: June 2018 - October 2018

To cite this article: Burdenko, E. V., Artsis, I. \& llyushchenko, N. (2018). International Theatrical Educational Programs: Moscow Art Theatre School Experience. Multidisciplinary Journal of Educational Research, 8(2), 179204. doi: 10.17583/remie.2018.3155

To link this article: http://dx.doi.org/10.17583/remie.2018.3155

\section{PLEASE SCROLL DOWN FOR ARTICLE}

The terms and conditions of use are related to the Open Journal System and to Creative Commons Attribution License (CC-BY). 


\section{International Theatrical Educational Programs: Moscow Art Theatre School Experience}

Elena Viktorovna Burdenko

Plekhanov Russian University

Natalia Ilyushchenko

Moscow Art Theatre School
Irina Artsis

Moscow Art Theatre School

\section{Abstract}

This paper presents research results regarding the creation, development and implementation of the international theatrical educational programs organized by the Moscow Art Theatre School together with leading American universities: the first program carried out together with the Eugene O'Neill Theatre Centre; the first international Master's theatre program carried out together with Carnegie Mellon University; the international Master's theatre program, which is currently being carried out together with the American Repertory Theatre at Harvard University, and the short-term international theatrical educational program carried out together with Wayne State University in Detroit (Michigan). The results confirm the necessity of carrying out international theatrical educational programs for training foreign students which is facilitated by the ongoing rise in global student mobility.

Keywords: education, international programs, mobility, Moscow Art Theatre School, Stanislavsky's system. 


\section{Programas Educativos Teatrales Internacionales: Experiencia de La Escuela de Arte de Moscú}

Elena Viktorovna Burdenko

Plekhanov Russian University

Natalia Ilyushchenko

Moscow Art Theatre School
Irina Artsis

Moscow Art Theatre School

\section{Resumen}

Este texto presenta resultados de la investigación sobre la creación, el desarrollo y la implementación de los programas educativos teatrales internacionales organizados por la Escuela de Arte de Moscú junto con las principales universidades de Estados Unidos: el primer programa llevado a cabo junto con el Centro de Teatro Eugene O'Neill; el primer programa internacional de teatro de maestría llevado a cabo junto con la Universidad Carnegie Mellon; el programa internacional de teatro de Maestría, que se está llevando a cabo actualmente junto con el Teatro de Repertorio Americano de la Universidad de Harvard, y el Programa Educativo Teatral Internacional a corto plazo con la Universidad Estatal de Wayne en Detroit (Michigan). Los resultados confirman la necesidad de llevar a cabo programas internacionales de educación teatral para la formación de estudiantes extranjeros, lo que es facilitado por el aumento de la movilidad global de los estudiantes.

Palabras clave: educación, programas internacionales, movilidad, Moscow Art

Theatre School, sistema de Stanislavsky

2018 Hipatia Press

ISSN: 2014-2862

DOI: $10.17583 /$ remie..2018.3155 
nton Chekhov had a considerable impact on the establishment and formation of the Moscow Art Theatre. The creative carrier of 1 Chekhov was studied in the works of other researchers as Ninov (In. Al'tshuller, Danilova \& Ninov, 1985) and Kovalev (1991). The problems of higher education were considered in the works of such scientists as Burdenko (2004, 2011), Kuzovlevy (2007), Pesochinsky (2007), Kulish (2007), Bazanova (2007), Gorina (2007), Sundstrem (2007), Perrotta (2013), Hamilton (2007), and others. The history of the emergence and development of the international theatrical educational programs carried out by the Moscow Art Theatre School found its reflection in "Family Albums" (Smeliansky, 2003, 2013) which are published for anniversaries. However, the complex research and the analysis of the development and carrying out of the international theatrical educational programs are conducted for the first time.

\section{Research}

The objective of this research consists in presenting the creation, carrying out and development of the international theatrical educational programs organized by the Moscow Art Theatre School from 1991 to 2016. The necessity of such programs is confirmed by the enormous annual growth in the number of students and the expansion of geography of the newly coming students from various US states and other countries.

\section{The Historical Aspect of the Idea of Creating the International Theatrical Educational Programs}

The idea of creating the international theatrical educational programs emerged in the 1920s when the Moscow Art Theatre (MHAT) came on its first tour to the United States. The productions of the Moscow Art Theatre made a great impression on the American theatrical community, the audience and Russian emigrants (Stanislavsky, 2009). At that time, the founder and art director of the theatre was Konstantin Stanislavsky, who elaborated his system of an actor's work on a role (Radishheva, 1999). 
In 1923, Richard Boleslavsky, a Moscow Art Theatre actor, who immigrated to the United States presented a series of lectures on Stanislavsky's system. Together with Maria Ouspenskaya, he later organized the American Laboratory Theatre (ALT). During the 7 years of its existence more than 500 young actors were trained in ALT. As Anatoly Smelyansky put it, Boleslavsky's pupil Lee Strasberg "started the great industry of Stanislavsky in America" (Smeliansky, 2003, p. 7). Thus, based on the elements of Stanislavsky's method, Strasberg's method appeared. The affective memory of an actor laid the foundation of the method (Nemirovich-Danchenko, 2012; Soloveva, 2005).

The ideas of Stanislavsky's system were utilized in The Group Theatre (1931-1941) which was founded by Harold Klyurman, Lee Strasberg, Stella Adler and Cheril Crawford. In 1947 The Actor's Studio in New York opened. From 1951, it was led by Lee Strasberg. In 1949 S. Adler opened the Studio of Acting. Later, in 1966 Strasberg L. and in 1986 Adler S. opened branches of their schools in Los Angeles. Marilyn Monroe, Jack Nicholson, Dustin Hoffman, Harvey Keitel were trained in The Actor's Studio. The Studio of Acting is considered to be a popular acting school offering a more universal and diverse range of skills and knowledge. Among the graduates of S. Adler's school are Marlon Brando, Robert De Niro, Nick Nolti, etc. Besides in 1969 a not-for-profit drama school called The Lee Strasberg Theatre and Film Institute opened in New York. It exists until present (Vinogradskaja, 2003).

Although Konstantin Stanislavsky and the Americans were both interested in carrying out international theatrical educational programs, the idea had never been realized in his lifetime. From the 1930s until the end of the 1960s the contact between the theatrical communities of the two countries was interrupted. Only in 1991 Stanislavsky's idea that American students and actors should come to the Moscow Art Theatre and study in Russia was put into practice.

The Moscow Art Theatre School was opened in 1943 under the direction of the Moscow Academic Art Theatre after Anton Chekhov to train students in acting skills under Stanislavsky's system. It has been training actors, directors, artists, set designers since then. Today the Moscow Art 
Theatre School Studio is the best theatrical institute in Russia. Its graduates include many famous Russian actors, directors, set designers and artists.

\section{Methodology}

In order to conduct the studies of the international theatrical educational programs directed by the Moscow Art Theater School, a retrospective analysis of the idea of the appearance of such programs was used. In addition, a retrospective analysis of the creation and implementation of the short-term and long-term international theatrical educational programs was used in the period from 1991 to 2016. A quantitative method was used to analyze the dynamics of mobility of the students coming from the United States and Canada to study at the Moscow Art Theater School between 2000 and 2016 (Utkin, 2017). The graphical representation allowed us to visualize the obtained data.

\section{Peculiarities of Organizing Joint International Theatrical Educational Programs}

The international educational programs of the Moscow Art Theatre School started in 1991 with the joint program with the Eugene O'Neill Theatre Centre which was called "Moscow Semester". The initiators of the program were:

- from the Russian side: Anatoly Smelyansky, professor, doctor of art criticism, vice rector of Moscow Art Theatre School; Alexander Rubinstein, professor, Doctor of Philosophy, founder and head of the department "Management and economy of performing arts" Moscow Art Theatre Schools;

- from the American side: George Whyte, founder of "Eugene O'Neill Theatre Centre"; Gregory Nersesyan, president of the American Soviet Theatre Initiative. 
In 1991, the first four American students came to Moscow. There was no customary infrastructure for foreigners: shops did not accept credit cards, there were no specially equipped classrooms and not all the teachers could speak English. These students were placed with host families. Therefore, it was necessary to adjust translation work, coordinate work with the students and organize their leisure. However, it should be noted that the best Moscow Art Theatre School teachers such as Oleg Tabakov, Anatoly Smelyansky, Michail Lobanov, Andrey Droznin were involved in the program (Smeliansky, 2003; Smeliansky, 2013).

Despite all the difficulties and faults, there was a huge desire to carry out such programs and the Moscow Art Theatre School learned to work with foreign students. The popularity of the program in the United States also made it possible. The American students coming from Russia spoke in rapture of their training in Moscow.

The making of the joint program took many years. In December 2016, the program's 25th anniversary was celebrated in Moscow and New York. To mark the occasion the US Ambassador to Moscow organised a reception for the management of the Moscow Art Theatre School and the American students who were trained in Moscow in December 2016. The event was highlighted in the press (Gostev, 2016).

To analyse the joint program with the National Theatre Institute one should start with the process of the enrollment of students. The selection of students takes place in various US colleges countrywide. The majority of American students, studying in liberal arts colleges, have an opportunity to choose together with major subjects the ones that are of interest to them. These subjects may be studied in another college and students will be granted credits. This is the rule on which the practice of "foreign semesters" is built. The costs of foreign training are usually covered by the college. This increases the mobility of American students and makes training abroad affordable for many of them.

The experience of the Art Theatre School had a considerable effect not only on dramatic art where its world impact is huge, but on other art forms as well, such as painting, music, cinematography, and, of course, on playwriting and literature. Anton Chekhov as a playwright was inextricably 
connected with the Art Theatre. The Art Theatre saw in Anton Chekhov its poet. That is why the teachers of the Moscow Art Theatre School place a particular emphasis on Chekhov's plays. His plays are of international character, they are understood by people all over the world: Russians, Americans, the British, the French, etc. as they make us think about the meaning of life and the reason for existence.

Every year, at the beginning of the autumn semester, the representatives of the National Theatre Institute tour various American colleges and tell about the educational programs of the Eugene O'Neill Theatre Centre and the joint program with the Moscow Art Theatre School. The application period starts in January and ends in late February of the following year. In March all the applications are thoroughly considered and the selection of students is made. At the end of April those who have been accepted into the program are notified of their enrollment.

The enrollment process of each new group takes practically a whole year. In September a group of American students comes to Moscow. Until the end of December they are trained by the leading teachers of the Moscow Art Theatre School.

\section{Results}

In the process of the study of international educational programs conducted by the Moscow Art Theater School in the period from 1991 to 2016, the following programs are singled out:

1. Long-term programs: Moscow semester - 3 months; International Master's Theater Program - 11 months;

2. Short-term program: 'Month in the Country' - 4 weeks. 


\section{'The Moscow Semester'}

The learning process at the Moscow Art Theatre School is different from that in American colleges and universities. In America students can choose disciplines and arrange their own training schedule to fit their timetable. The Moscow Art Theatre School has strict limits. The time-table for the whole semester includes daily classes from 10 a.m. to 6 p.m. They are all most necessary disciplines. As a rule, in the first half of the day there are movement, stage combat, vocal, dance, fencing classes. The second half of day is completely devoted to acting skills. Besides, students attend lectures on stage and set design, the history of theatre, the history of cinematography. The international theatrical educational program "The Moscow Semester" includes the following related parts:

1. The educational part, which consists of teaching vocational and general subjects;

2. The cultural part aimed at the students' immersion in the Russian drama theatre and culture;

3. The organizational part, which is an opportunity to get acquainted with Russian fellow students;

4. The infrastructure: location, accommodation and food.

The related parts of the International theatrical educational program are presented in Figure 1. 


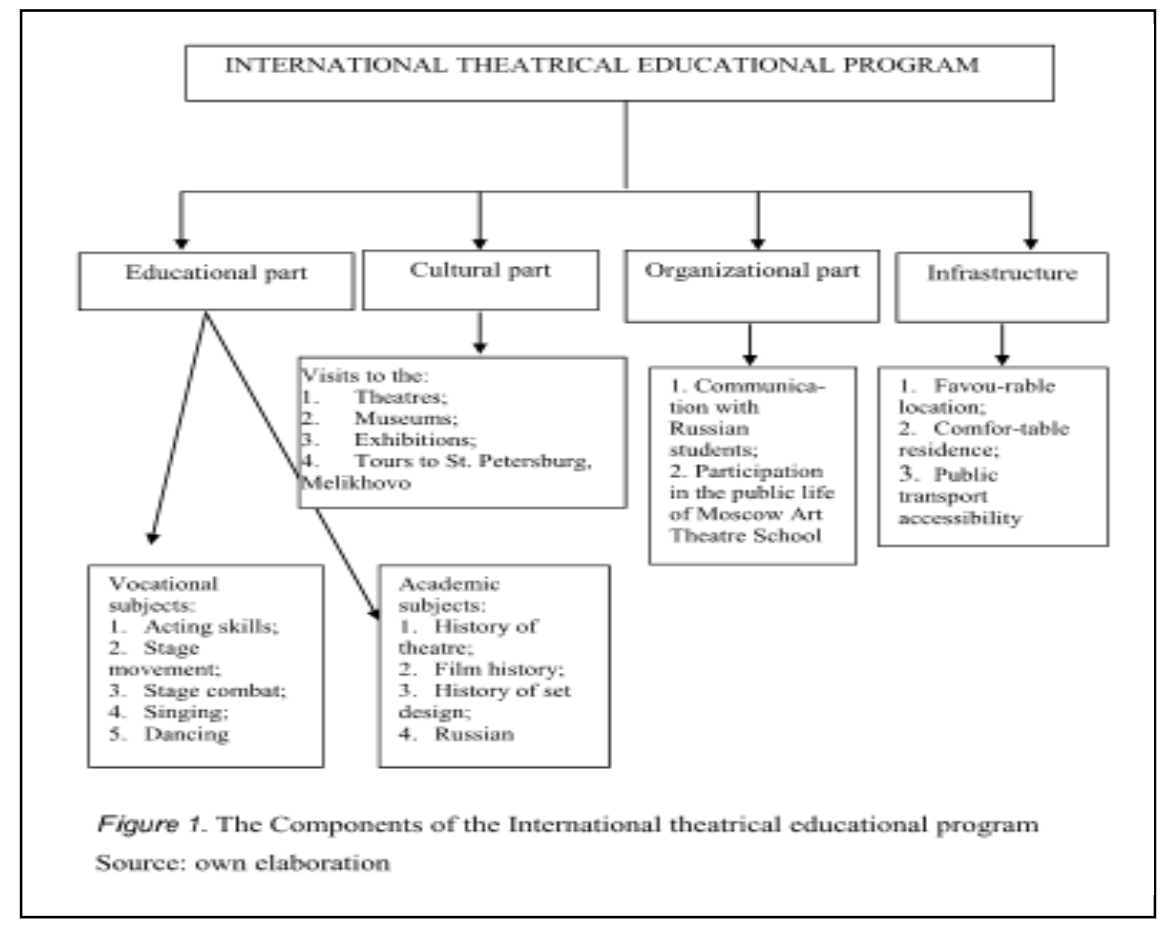

Each related part of the program involves:

\section{The educational part, which consists of vocational and general} subjects. The most difficult subjects for students are the subjects which require physical training. However, upon completion of the program the result is always visible. Many students make considerable progress in stage movement, stage combat, dancing and fencing. Training in each subject ends up with an exam.

The American students master the program of acting skills within 3 months while the Russian students study it during their first year at school. The classes start with concentration exercises and scene studies: 'I am in the given circumstances'. 
For many foreign students acting classes are the experience they have never had before. For the first time they deal with a system approach to mastering their profession. That is why such classes are especially important for them. Gradually separate episodes of the play, which students have to perform at the end of the semester become the topic of their scene study. In this particular case the performance of the play before the audience on the stage of the educational Studio School theatre is considered as their exam.

For the implementation of international theatrical programs our leading teachers developed special teaching methods which did not only include training under Stanislavsky's system, but also the method created by Mikhail Chekhov (2007) who is well-known in the West. His book on the technique of acting was originally written in English and published in America. He started his own theatre school in England, which before World War II moved to the USA where it turned into a professional theatre called 'The Chekhov Theatre Players'. The company gave several performances on Broadway and began touring all over the country, promoting the principles of theatre art.

Mikhail Chekhov developed several stages of an actor's work on a role called 'ways of rehearsing'. This acting technique was later successfully applied by our teachers in training American students. They developed special exercises on concentration and imagination, and on creating the atmosphere while working on the character in scenes and in the performance overall (Chekhov, 2007).

Special attention is paid to the psychological gesture during the first stage of working on a role as an expressive gesture is a basis for the implementation of the artistic conception of the role (NemirovichDanchenko, 2012). A system of exercises was developed in which by means of a psychological gesture it is easier for the student to evoke his own emotions and fill the role with a particular meaning. Mastering the technique of a psychological gesture, the students can go deeper into the plays of Russian writers such as Anton Chekhov, Foydor Dostoyevsky, Nikolay Gogol, and others.

Great attention is attributed by our teachers to improvisation during the student's work on a role. They create such situational exercises which help 
develop students' creative thought, train them to work on their own and find "keys" which open their creative "doors". When getting down to work on the scenes from Chekhovian plays (Stanislavsky was the first to find the key to Chekhov's dramatic art), our teachers, first of all, do psychological analysis of a play. They strive to reveal to the students the profound and intensive inner life of a character, constantly repeating after Konstantin Stanislavsky that an uninterrupted physical action - i.e. "the line of life of a human body" takes a special place in the portrayal of any character (Psychological Basis of Stanislavsky's System, 2009).

According to Stanislavsky (1999), inner emotions and actions brought to life help to understand the core of a character, his subtext, which is hidden behind words - "the life of a human spirit" (p. 39). All these are tested in scene studies. It helps a drama student to select typical traits for the character and penetrate more deeply into the psychology of the character created.

Another important component in actor training is tempo-rhythm exercises, which help the students to loosen up, have better control of their body and find a certain tempo and rhythm for each character. This is the main task of such exercises.

The most important thing is that all these exercises are done systematically throughout the whole program. That is why most students manage to master the material and it is a lot easier for them to start rehearsing separate scenes and acts of the performance.

The question of independent work during etude studies plays a very important role. Our teachers constantly urge the students to work actively both at rehearsals and at home during their free time. They are constantly explaining to the students that only they themselves can exist in the characters they create. The teachers, in their turn, help them to reveal the super-objective and explain the circumstances of the role, etc. Without a true emotion on the stage everything ends up lifeless and uninteresting. In doing scene studies a drama student can express in his own words what later will be expressed by the author's text. This stirs up the student's imagination and helps him to capture the inner and outer world of the character. Our teachers analyze, direct and delicately and tactfully correct the work of drama students, thus helping them to create "a living person" on 
the stage. All these make the international theatrical educational program more attractive and useful.

Except for the disciplines aimed at mastering acting, the students also study general subjects. They have to read plays by great Russian playwrights such as Anton Chekhov, Alexander Ostrovsky, Nikolay Gogol, Foydor Dostoyevsky. It is necessary for them to read a lot of books on theater history. As they do not know the Russian language a three-month course of Russian is organized for them (Lisina, 2016). The students have three classes a week which are conducted by our Russian teachers. The knowledge of the Russian language helps them find their bearings around the city and makes their communication with fellow-students and teachers easier.

2. Cultural part aimed at immersing the students into the Russian drama theatre and culture. The cultural program is an important part of the international theatrical educational program. In their free time in the afternoon and in the evening the American students go to theaters, exhibitions, museums, visit the country house museum of Anton Chekhov in Melikhovo and travel to St. Petersburg. The program enables the students to see the productions of various directors, performances of different cultural styles in the best Moscow theaters.

All the productions are further discussed with teachers during the acting classes and lectures on theater history. For many foreign students such frequent theatre going is very unusual. Despite their desire to become actors they don't go to the theater so often in America.

\section{Organizational part which is an opportunity to get acquainted} with Russian fellow students. From their arrival in Russia and during the whole period of training American students are accompanied by the students of the Arts management faculty. The first-year students who have a perfect command of the English language are informally called "angels". They accompany the American students to theatres and exhibitions; help to find the way in the subway, solve the arising problems, such as a visit to a 
doctor, purchase of necessary things. Communication with the American students is a good language practice for the Russian students and a good opportunity to learn more about the culture of another country. For the American group communication with the Moscow Art Theatre School students is also a useful practice and another source of information about Russian culture and life. Together with the Arts management students the students of the faculty of Set Design and Theatrical Technology are also involved in the work with the American students. They help to stage a performance: create necessary scenery, costumes, and props.

Besides, the American students participate in the students' life of the Moscow Art Theatre School. Together with the Russian students they take part in the events held by the Studio School and the Theatre. Every fall a student-initiation ceremony is held at the Moscow Art Theatre School., which is an informal amateur students' concert party called "Kapustnik". The American students always take part in it. They prepare their own show and perform it on the Small Stage of the Chekhov Moscow Art Theatre. When the Chekhov Moscow Art Theatre celebrates such commemorative events as Anatoly Smelyansky's anniversary or the Moscow Art Theatre School anniversary on the Main Stage, foreign students participate in them. The opportunity of appearing on the historical stage of the theatre will survive in their memory for a long time.

4. Infrastructure: location, accommodation, food. Building location in the city is an important component, which works for the image of the School. The Moscow Art Theatre School is located in the historic theatrical center, Kamergersky Lane, which is within a walking distance from Red Square. From there you can easily walk to such theatres as the Chekhov Moscow Art Theatre, the Moscow Operetta State Academic Theatre, the State Academic Bolshoi Theatre, the State Academic Maly Theatre, Yermolova Moscow Drama Theater, the Russian Academic Youth Theater, the Stanislavsky and Nemirovich-Danchenko Moscow Academic Music Theatre, the State Theater of Nations. In 2016170 drama, musical, children's theaters, puppet theatres worked in Moscow. 
Today the newly-arrived students are not placed with host families. They live in a comfortable theater hostel which is not a long way from the school. It is easy to get there by public transport - by subway or by bus. The atmosphere in the theatre hostel is homelike, the premises has been renovated, there is a rehearsal room, a gym, Wi-Fi network.

Today Kamergersky Lane has changed, it has become a pedestrian area which is pleasant to walk. On the first floors of the buildings located in Kamergersky Lane there are lots of cafes, bakeries and snack bars. So here there is no problem where to eat. Sitting in a cafe over a cup of fresh-made coffee, you can discuss what happened during the day, talk about future plans or just socialize.

On their return to the USA many American students say that the program was quite difficult, but interesting. For many of them The Moscow Semester becomes a challenge, as they are not used to such an academic load. It is in the Moscow Art Theatre where most American students begin to understand how professionals work and the theatre setup. The program makes them think whether they are really ready to devote themselves to the profession of an actor. Many graduates continue their master's degree program and stay with the theater. But some of the American students are not ready for such a job, so they work in another area.

From 1991 to 2016 the program was carried out 25 times and trained almost 500 American students. The number of students who completed The Moscow Semester program at the Moscow Art Theatre School from 2004 to 2016 is illustrated in Figure 2 below. 


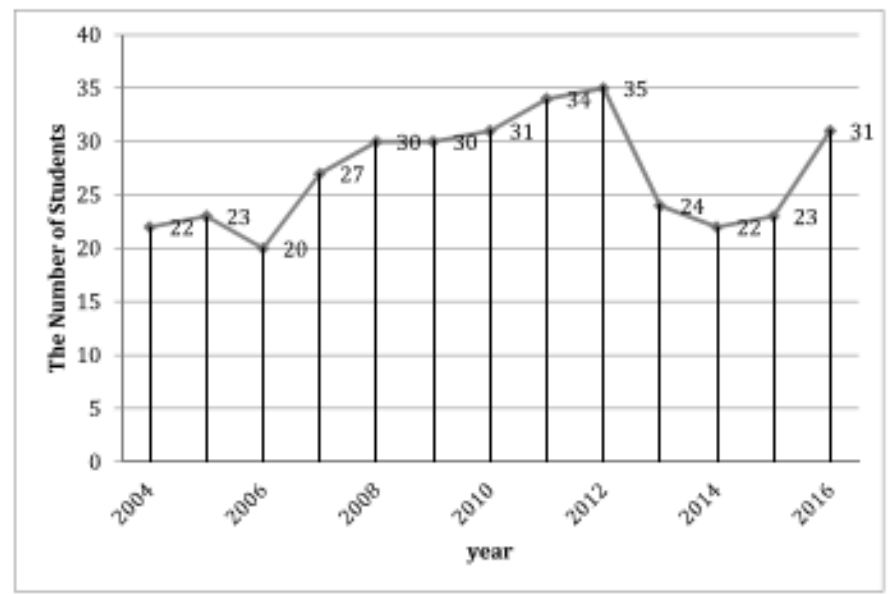

Figure 2. The number of American students who trained in The Moscow Semester program at Moscow Art Theatre School from 2004 to 2016

\section{A.R.T/Mhat Institute for Advanced Theater Training at Harvard University}

In 1997 the joint international Master's theatrical program of Moscow Art Theatre School and the American Repertory Theater at Harvard University was launched. This program enables the students to continue their training in acting skills. It is the highest level in acting training. The selection of students takes place in four main theatrical centers of the USA: New York, Boston, Chicago and San Francisco. Every year the program enrolls 18 actors and several dramaturges and speech teachers.

As a result of this program the American Studio was opened at the Moscow Art Theatre School. The management of the international Master's 
program in collaboration with the American Repertory Theater developed a project of the reconstruction of the classrooms, invested in it and carried it out. The penthouse located in Kamergersky Lane 3a was repaired, and a rehearsal hall, classrooms and a small office were built. It is a model of a professional theater. Today the American students who come to the Moscow Art Theatre School have their own premises.

The Master's program is available for those who have already left colleges and have professional acting experience. The students study for 2 years and 3 months to get a Master's degree. The Moscow Art Theatre School teachers take part in this program during the whole training period. In summer an acting teacher from the Moscow Art Theatre comes to Cambridge and starts the program at Harvard. In addition to acting, Russian teachers also train the students in speech and movement. First of all the students are acquainted with the educational system of the Moscow Art Theatre School. Then they do the autumn semester under the American teachers and in spring they come to Moscow to continue their training.

These students have already chosen an actor's career, and it is essential for them to master new skills and grow professionally. The program implies an intensive course from morning till evening. At the end of the semester the students do final tests in the disciplines they have studied. For that, heads of the program come from Harvard to estimate the results of the work during The Moscow Semester. The spring and the fall semester do not differ much in their curriculum. The American students have very limited time to master what the Russian students study for 4 years.

During the semester, the students not only study, but also rehearse the performances which are later shown on the Student theater stage. Due to the master's program productions in English are now included in the repertoire of the Student Theatre of the Moscow Art Theatre School. Actually the American Studio of the Moscow Art Theater School has become the only functioning English language theatre in Moscow which has its own spectators. The productions of the American studio attract the audience by providing them with an opportunity to get to know American culture and theater.

The productions in English were presented at various theater festivals in Russia: 
- in 2010 Alice against the Wonderland was shown at the festival Your Chance and received an award;

- in 2012, The Imaginary Invalid was shown at the festival Your Chance as well as at The Future of Theatrical Russia, Yaroslavl Theater Festival, and received positive reviews;

- in 2014, Ivanova and Uncle Vanya were shown at the Melikhovsky Spring Festival.

When the program was started the following practice was used: the performance was preliminary rehearsed with an American director in the USA and then it was transformed to the Russian stage. But in 2014 the preparation procedure was changed. A director from Russia comes to America and during the winter semester he starts his work on the production which is completed in March on the Moscow stage. Thus, The Idiot by Fyodor Dostoevsky was released in 2014 (the Moscow Art Theater Director Marina Brusnikina adapted the novel for the stage). In 2015 two plays were produced: The Lonely Voice adapted from the short stories and personal letters of Ivan Bunin and A Profitable Position by Alexander Ostrovsky (directed by Ilya Bocharnikovs).

Such a practice appeared to be time-consuming. It is quite difficult to adjust a new production to another stage and thus a new production is directed in Moscow during a short period of time. It is not only necessary to learn the lines, but also to choose the right costumes for the cast, build up the scenery, adjust the lighting and sound. During the play rehearsal, all undergraduates gain invaluable professional experience.

The students from the Arts Management faculty help the American Studio with the organization of the production. The students from the faculty of Set Design and Theatrical Technology are responsible for the stage scenery. The participation in the program also helps the Russian students to gain new professional experience.

The master's program trains not only actors but dramaturges as well. In the American system the profession of a dramaturge implies close cooperation with the director and the author of the literary work. His responsibilities include collecting all the necessary information about the life of the author, history of the productions, working on the literary 
context, historical outline, writing of play summaries, etc. The attendance of a large number of performances is very important for dramaturges. They have to be well informed of various interpretations of literary works and new theater trends. That is why they should study the Russian language more intensively. In the framework of the program they study the history of the Russian theater, the history of drama, modern drama, the history of arts and the history of set design. All the disciplines are taught with a focus on a deeper understanding of the Russian theater and culture.

During the whole semester dramaturges keep records of their stay in Moscow. These diaries are further published on the website of the Moscow Art Theatre School. Everyone can read and learn the opinion of young Americans of a particular theatrical event, a stage director or about Russia. An obligatory element of training is the participation of a dramaturge in the work on the performance, which is later staged in Moscow. A dramaturge has to collect all the necessary information, to work with the director, the designer and actors.

Upon completion of the Master's program the students receive a Master's degree from the Moscow Art Theater School and Harvard University provides them with an opportunity to join the actor's labor union (American Equity Association, AEA).

As is estimated nearly 400 American students have received a degree since 1997. The number of the American students studying from 2000 to 2016 is illustrated in Figure 3 below. 


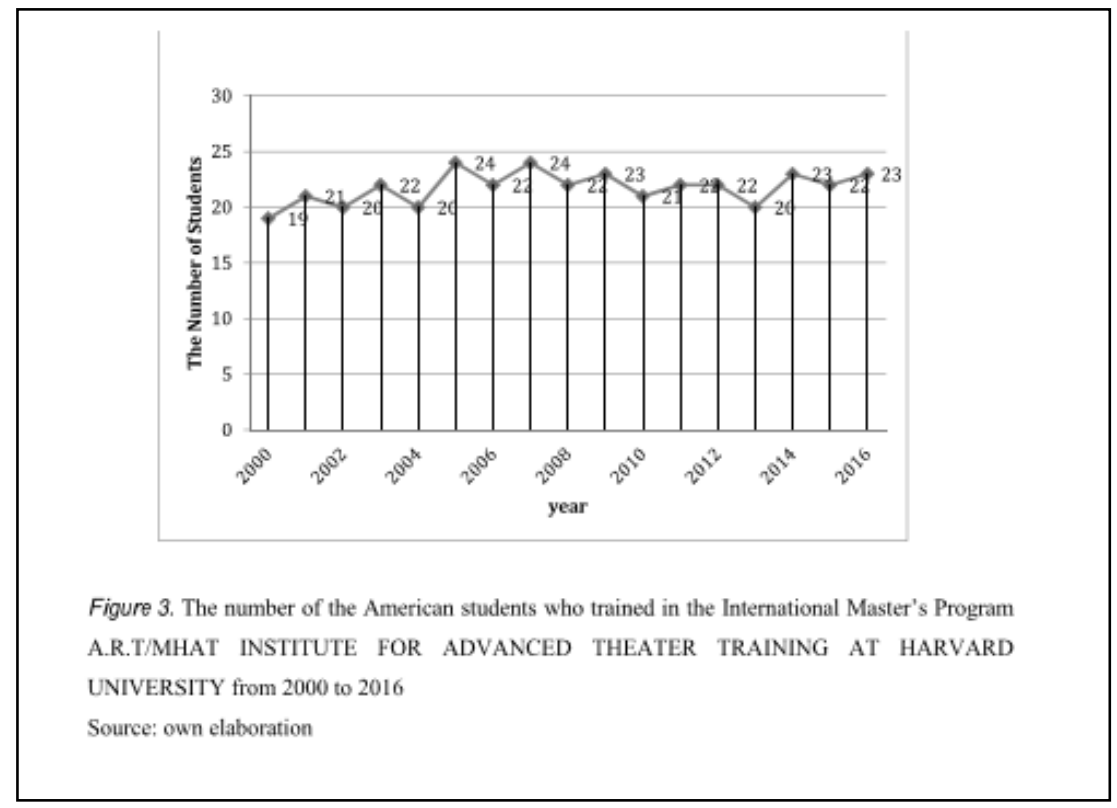

\section{'Month in the Country'}

Due to the cooperation of the Moscow Art Theatre School with Wayne State University in Detroit, Michigan, a short-term international theatrical educational program was launched. It is carried out annually in June. The program began in 2003 and is still on the go. On the American side, it is supervised by James Thomas. The program received its name from Ivan Turgenev's play A Month in the Country.

The program was designed not only for drama students, but also for theatre artists, theatre managers, etc. It is important to note that James Thomas enrolls not only Wayne State University students, but also those from University of Windsor in Canada. So, the American and Canadian students study in one group. It is a four-week undergraduate and master's program. 
The program 'Month in the Country' is of great importance for future actors as it enables them to acquire profound knowledge of the training process at the Moscow Art Theatre School and get acquainted with Russian culture and art. The program is focused on intensive training from morning till evening, and the students also visit theaters in the evening or during their leisure time.

From 2003 to 2016, more than 220 students were trained under this program. The number of the American students trained under the international theatrical educational program 'Month in the Country' at the Moscow Art Theatre School from 2004 to 2016 is illustrated in Figure 4. The program is much regarded among American students.

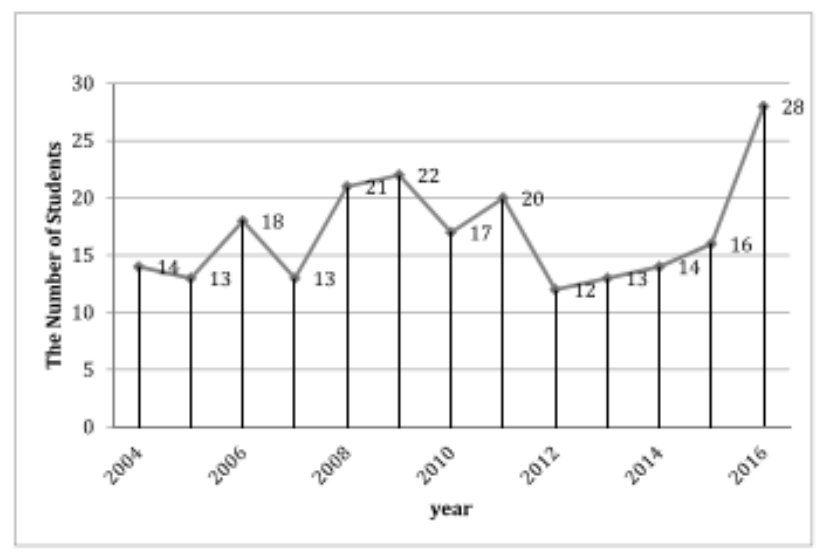

Figure 4. The number of the American students who trained in the International theatrical educational program 'Month in the Country' at Moscow Art Theatre School from 2004 to 2016 Source: own elaboration 


\section{Solutions and Recommendations}

As a result of the retrospective analysis it was revealed that the Stanislavsky system is successfully used for professional training of actors. The Stanislavsky system is a living method, passed from teacher to student, regardless of nationality. It has been used for 100 years to train actors in different countries of the world and continues to be relevant.

According to our research, the analysis of the dynamics of mobility of foreign students coming to study international theatrical educational programs of the Moscow Art Theater School has confirmed the steady demand for such programs.

In the process of our study, four interrelated parts of international theatrical educational programs are singled out, which allow to achieve higher professional training of foreign students: educational, cultural and organizational parts as well as infrastructure. Therefore, the results of our research are important for understanding the process of professional training in theatrical specialties.

The research of the international theatrical educational programs of the Moscow Art Theatre School shows that the creation and carrying out of such programs are still of immediate interest. In the cultural and art spheres, and especially in the theatrical sphere, real life communication of professors with foreign students is very important. In this case, all ways of conveying information are used to provide better training. The unique pedagogical experience of the Moscow Art Theatre School ensures a successful implementation of both short-term and long-term educational programs. The most complete training is received by the foreign students in Moscow where all the related parts of the international educational program are effectively utilized.

\section{Conclusion}

The Moscow Art School nurses the best traditions and achievements of theater arts. It is common knowledge that Stanislavsky's system plays an exclusive role in the development of dramatic art and theatre pedagogy. That is why the international theatrical educational programs are becoming 
so popular among foreign students. The modern Russian drama school uses various teaching approaches and methods based on Stanislavsky's system which include the Scene Study Method, the Method Acting Analysis, the Method of Physical Action. When working with students our teachers combine and individually apply all the said methods, which is fundamentally different from theater training in other countries. For example, in the USA the students study in different art schools, which have their own methods of training. The international educational program of the Moscow Art Theatre combines the experience of different schools in acting training which makes the program unique. It gives the students an opportunity to study various approaches of which Stanislavsky's system is the basis. As a result, drama students acquire the basis of professional acting skills within rather a short period of training (in the fall/winter semester, or within one summer month). The main objective of the international theatrical educational programs is to teach an actor to work alive. Our teachers successfully implement the creative process of teaching all-round actors. The stage acting is perceived as a logical and successive process which takes place in the "given circumstances". The scene study method, which is widely used in training, helps the students to master Stanislavsky's system in its modern sense.

Along with the class work, our acting teachers work individually with each student, helping them, at their request, to prepare monologues from A.P. Chekhov's plays for future theater casting in the USA or other countries. Aside from the participation in bits, it helps the students during the individual work to better understand the main idea of a play by using various expressive forms, which gives them a feeling of freedom and an ability of self-expression. All these make the international theatrical educational program especially attractive to foreign students including those who are determining their life journey.

The international theatrical educational programs for training foreign students, developed by the Moscow Art Theatre School have become a real breakthrough in teaching drama art to foreign students. These programs attract an increasing number of enthusiastic followers in other theatre schools of Russia. The rotation of the material and tasks of each part of the program helps to add considerable variety to presenting the material and 
use different types of activities to make the learning process more active and effective. The program provides a comprehensive range of exercises from simpler ones to scene studies, and finally to extracts from various works by Russian classics. All these allow the students to master the material more quickly and with a good result. Many exercises are intended for students' individual work to broaden their mind. Such exercises are, as a rule, checked and discussed with students and professors in the auditorium, which creates a special working atmosphere. The literary works and extracts from plays which the students will later perform onstage are carefully discussed. It all makes the international theatrical educational programs especially attractive to foreign students. The acquaintance with the Russian psychological theater is a real discovery for the students. It allows them to deeper penetrate the portrayal of different characters and expands their creative potential.

The enormous annual growth in the number of students and the expansion of geography of the newly coming students from various US states and other countries confirm the necessity of such programs.

\section{Acknowledgment}

To Supporting Agencie: Moscow Art Theatre School.

\section{References}

Al'tshuller, A., Danilova L., \& Ninov, A. (Eds.). (1985). Chekhov and the theater. Leningrad: RSFSR.

Burdenko, E. (2004). Education market in the transformed economy. Moscow: OOO MAKS.

Bazanova, V. (2007), The training of artists in the Russian drama school. In. Kostina, E., Pashina, O., Strutinskaja, E., \& Ushkarev, A. (Eds.). History of art education in Russia (pp. 218-225). Sankt-Peterburg: Kompozitor.

Burdenko, E. (2011). Federal budget for 2012-2014: a tool for the modernization of the Russian economy. The quality of educational services in innovative economy (pp. 90-95). Conference. Moscow: REU. 
Chekhov, M. (2007). Mikhail Chekhov, actor's life and meetings. Moscow: AST.

Gorina, T. Theatre school of Russia In. Kostina, E., Pashina, O., Strutinskaja, E., \& Ushkarev, A. (Eds.). History of art education in Russia (pp. 226-233). Sankt-Peterburg: Kompozitor.

Gostev, I. (2016). 25th Anniversary celebration of the joint program of Moscow art theatre school and the Eugene O'Neill Theatre Centre. Vedomosti, 4225, 5-12.

Hamilton, J. R. (2007). The Art of Theater. Victoria, Australia: Blackwell Publishing. DOI: 10.1002/9780470690871 .

Kovalev, V. (1991). Anton Chekhov's career. Moscow: MHAT.

Kulish, A. (2007). Training of actors, Directors and artists of the puppet theater. In. Kostina, E., Pashina, O., Strutinskaja, E., \& Ushkarev, A. (Eds.). History of art education in Russia (pp. 202-218). SanktPeterburg: Kompozitor.

Kuzovlevy, T. History of theatre education in Russia. In. Kostina, E., Pashina, O., Strutinskaja, E., \& Ushkarev, A. (Eds.). History of art education in Russia (pp. 162-175). Sankt-Peterburg: Kompozitor.

Lisina, E. (2016). Three conditions of the survival of the American students from the theatrical faculties during their training period at the Moscow Art Theatre School. Journal of Ammosova North-Eastern Federal University. Pedagogy. Psychology. Philosophy.2, 18-22.

Yakutsk: North-Eastern Federal University in Yakutsk.

Nemirovich-Danchenko, V. (2012). Creative heritage in four volumes. Letters from the past. Moscow: MHAT.

Perrotta, A. (2013). Theater school: Students as actors and writers for the stage. PA: IGI Global. doi: 10.4018/978-1-4666-21220.ch041./72092/

Pesochinsky, N. Education of actors and Directors in the Russian theater school . In. Kostina, E., Pashina, O., Strutinskaja, E., \& Ushkarev, A. (Eds.). History of art education in Russia (pp. 175-201). SanktPeterburg: Kompozitor.

Psychological Basis of Stanislavsky's System . (2009). Moscow: AGI. Radishheva, O. (1999). Stanislavsky and Nemirovich-Danchenko: History of the theatrical relations: 1917-1938. Moscow: Artist. Theater. 
REMIE-Multidisciplinary Journal of Educational Research, 8(2)203

Sundstrem, L. (2007). Training of theatre managers. In. Kostina, E.,

Pashina, O., Strutinskaja, E., \& Ushkarev, A. (Eds.). History of art education in Russia (pp. 234-239). Sankt-Peterburg: Kompozitor.

Smeliansky, A. (2003). Family album. Moscow: MHAT.

Smeliansky, A. (2013). Family album. Moscow: MHAT.

Smeliansky, A., \& Soloveva, I. (1998). Moscow art theatre school. A hundred years. Moscow: MHAT.

Soloveva, I. (2005). Bokshanska's letters to V. Nemirovich-Danchenko. Vol. 1 and Vol. 2 . Moscow: MHAT.

Stanislavsky, K. (1999). Collected works in nine volumes. Letters of 19181938. Moscow: MHAT.

Stanislavsky, K. (2009). My life in art. Moscow: AST Zebra E.

Utkin, V. (2017). Econometrics. Moscow: Dashkov and K.

Vinogradskaja, I. (2003). K. Stanislavsky's life and creative work.

Chronicle, 3. Moscow: MHAT. 
204 Burdenko, Artsis \& Ilyushchenko - Theatrical Programs

Elena Viktorovna Burdenko is Associate Professor of Political Economy and Economic History of Science, from Plekhanov Russian University of Economics. Russian Federation

Irina Artsis is Professor of the Moscow Art Theater, the Faculty of Foreign Languages, the Moscow Art Theater School; the first head of the American studio of the Moscow Art Theater, a simultaneous interpreter.

Natalia Ilyushchenko is Professor of the Moscow Art Theater; Candidate of Philology, Associate Professor of the Higher Attestation Commission of the Russian Federation

Contact Address: Elena Viktorovna Burdenko. Moscow Art Theatre School. Tverskaya Street, Building 6, page 7. Moscow, Russian Federation. 125009

Phone: +7 495 629-39-36 (training department)

E-mail: Burdenko-EV@yandex.ru or producer@mxat-school.ru 


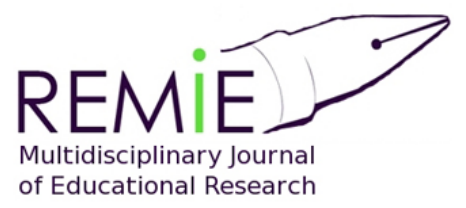

Instructions for authors, subscriptions and further details:

http://remie.hipatiapress.com

\section{La Emancipación en Educación Ambiental: Formación en una Universidad Brasileña}

Daniela Cassia Sudan ${ }^{1}$, Vânia Gomes Zuin ${ }^{1 / 2}$

1) Universidade Federal de São Carlos, Brasil

2) The University of York, UK

Date of publication: June $15^{\text {th }}, 2018$

Edition period: June 2018 - October 2018

To cite this article: Sudan, D. C.\& Zuin, V. G. (2018). La Emancipación en Educación Ambiental: Formación en una Universidad Brasileña.

Multidisciplinary Journal of Educational Research, 8(2), 205-230. doi:

10.17583/remie.2018.3203

To link this article: http://dx.doi.org/10.17583/remie.2018.3203

\section{PLEASE SCROLL DOWN FOR ARTICLE}

The terms and conditions of use are related to the Open Journal System and to Creative Commons Attribution License (CC-BY). 


\section{Emancipation in Environmental Education: Training at a Brazilian University}

Daniela Cassia Sudan

Universidade Federal de São

Carlos
Vânia Gomes Zuin

Universidade Federal de São

Carlos/University of York, UK

\section{Abstract}

Based on Critical Theory and Emancipator Environmental Education, the study aimed at analyzing the dialectic of emancipation and its potentials in Environmental Education (EE). The research method was structured following a qualitative, participatory research approach, which includes focus group techniques and documental textual analysis. The category "dialectic of emancipation in the socioenvironmental training project" was priorised here, with the sub-categories "emancipation", "emancipator EE", "autonomy" and "freedom". It was observed that the potential emancipator elements include the contradictions in the processes of education and in the bureaucratic and power relations of the institutions that can limitate the autonomy and freedom of individuals, besides the valorization of the experience in collectives in search of the democratization of the EE, as a potential for reflections and critical actions within the HEI.

Keywords: emancipation, Critical Environmental Education, higher education, Critical Theory. 


\section{La Emancipación en Educación Ambiental: Formación en una Universidad Brasileña}

Daniela Cassia Sudan

Universidade Federal de São

Carlos
Vânia Gomes Zuin

Universidade Federal de São

Carlos/University of York, UK

\section{Resumen}

El objetivo de este artículo es mostrar resultados sobre el analice de un proyecto de formación socio ambiental desarrollado - en un sentido emancipador - junto a servidores públicos de una Institución de Educación Superior (IES) brasileña. Con base en el referencial de Teoría Crítica y de Educación Ambiental Emancipadora, el estudio buscó analizar la dialéctica de la emancipación y sus potenciales en Educación Ambiental (EA). El método de investigación fue cualitativo, participante, con técnicas de grupo focal y análisis textual de documentos del grupo coordinador del proyecto. Entre los resultados, se observó que los elementos potenciales emancipadores incluyen las contradicciones en los procesos de educación y en las relaciones burocráticas y de poder de las instituciones que obstaculizan la autonomía y la libertad de los sujetos participantes. A la vez, se percibió la valorización de la experiencia en colectivos en busca de la democratización de la EA, como potencial para reflexiones y acciones críticas en el interior de las IES.

Palabras clave: emancipación, Educación Ambiental Crítica, educación superior,

Teoría Crítica 


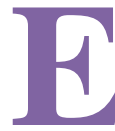

ducación Ambiental (EA) y de las universidades en ese sentido, la búsqueda por la emancipación se vuelve casi qué objetivo compartido en los programas socio ambientales. La vertiente crítica de la EA anuncia la emancipación como siendo fundamental para llegar a sociedades sostenibles, al mismo tiempo en que se constata una deficiencia sobre el significado de esta en ese campo de praxis (Sudan, 2017).

Zerbini (2008) profundiza la temática de la emancipación en la EA y observa concordancia (casi unánime de sus entrevistados - especialistas brasileros de renombre en el área) por una mayor aclaración de la propuesta de EA emancipadora asociada a los procesos educacionales, respetando la característica de la incertidumbre e incompletud como condiciones fundamentales de su práctica y utopía. En Brasil, diversos autores señalan un crecimiento elevado de investigaciones en EA durante el inicio del siglo; lo que puede ser evidenciado en eventos de investigación, en el aumento de cursos de post-grado stricto sensu, en la creación de revistas y periódicos específicos y en la institución de la Política Nacional de Educación Ambiental (Brasil, 1999), entre otras acciones derivadas (Carvalho \& Farias, 2011; Carvalho; Tomazzello \& Oliveira, 2009). Sin embargo, Goergen (2010) apunta que el área todavía carece de un debate teórico metodológico de fondo sobre, por ejemplo, la ciencia, sus sentidos y rumbos. En este sentido, es "necesario intensificar el diálogo entre educación ambiental, política y economía", siendo esta última un "aspecto neurálgico" en el debate ambiental, constituyéndose en "brazo ejecutivo de la razón instrumental" (p.29).

Cuando discuten tipologías de investigaciones en EA en América del Norte y Europa, Sauvé (2000) y Costa y Silva Maia (2017) lamentan que las investigaciones críticas en EA sean escazas y recientes. De la misma forma, González-Gaudiano y Lorenzetti (2009) indican una hegemonía de investigaciones "no-críticas" en América Latina, enfatizando la necesidad de "dar nuevo impulso al debate ontológico, epistemológico, paradigmático y metodológico" a las mismas, delante de la primacía de directrices empíricas y positivistas, de una visión instrumental (González-Gaudiano \& Lorenzetti, 2009, p.207). 


\section{Sudan \& Zuin - Emancipación y Educación Ambiental}

Delante de esa deficiencia, este artículo se propone a discutir los sentidos de la emancipación a partir de un recorte de una investigación empírica (tesis de doctorado de la primera autora), a la luz de los referenciales de la Teoría Crítica y de los contornos de la EA crítica en América Latina y Brasil (Gaudiano \& Lorenzetti, 2009; Layrargues \& Lima, 2011; Zuin \& Pacca, 2013; Sjöström, Frerichs, Zuin \& Eilks, 2017). A lo largo del texto discutiremos qué elementos emancipatorios emergieron del proyecto durante su desarrollo y evaluación por el grupo coordinador, a partir de sus datos y producciones. También discutiremos de qué manera dichos elementos contribuyen para la discusión de emancipación en la Educación Ambiental. A seguir, presentaremos el proyecto objeto de estudio empírico y sus potencialidades emancipadoras en la Educación Ambiental en universidades.

\section{Sobre la Investigación en Foco}

La institución involucrada en la investigación tiene 11 campi universitarios, distribuidos en diversas ciudades del Estado de Sao Paulo, Brasil, con una comunidad universitaria de aproximadamente 120.000 miembros. El proyecto de EA analizado fue desarrollado durante el periodo de 2013 a 2015, con la meta inicial de desarrollar un proceso presencial de formación socio ambiental de cerca de 17.000 servidores técnicos y administrativos de niveles: primaria, secundaria/técnico y superior de esa institución, durante un período de tres años. Para propiciar la Educación Ambiental a cada servidor, fue adoptada una arquitectura de formación de colectivos educadores en capilaridad (en niveles diferenciados, denominados PAP1, PAP2, PAP3 y PAP4) inspirada en una política pública brasilera (Programa de Formación de Educadores Ambientales / ProFEA, Brasil, 2006). El termino PAP incluye dos significados que se articulan: "pesquisa-açãoparticipante" ("investigación-acción-participante") y "personas que aprenden participando", con principios de una perspectiva crítica de EA, fomentando praxis en colectivos educadores (Ferraro Junior \& Sorrentino, 2005).

La propuesta de capilaridad ocurría con una instancia de Gestión Ambiental (comprendida en la red de capilaridad como un colectivo 
educador PAP1) en el papel de elaborar y coordinar la propuesta de formación junto a servidores con experiencia en el área ambiental (PAP2). A los PAP2 les correspondía promover cursos en sus unidades de trabajo para otros servidores, los PAP3. Estos también tenían que elaborar y desarrollar una intervención educadora, de corta duración, con los PAP4. Fue exigido, como condición básica para adhesión a la Formación, el desarrollo de prácticas educadoras socio ambientales por los PAPs2 y PAPs3 en sus locales de trabajo. El plano político pedagógico (PPP) de dicho Proyecto de Formación fue estructurado con repertorios conceptuales, situacionales y de práctica local (Brasil, 2006), abordando contenidos de Educación, Educación Ambiental, Sostenibilidad y Gestión ambiental, a partir de actividades de diferentes naturalezas (palestras, conferencias, seminarios, estudios teóricos, visitas de campo, dinámicas de grupo, recopilación de datos etc.) que fueron desarrolladas e incrementadas con los PAP2, PAP3 y PAP4 en sus respectivos campi universitarios. Al final del proceso, habían 2500 servidores, con la promoción de 31 cursos presenciales de $(40 \mathrm{~h})$ sobre socio ambiente promovidos por los 92 PAP2. De esos cursos participaron 533 PAP3. Las acciones de Educación y gestión Ambiental de los PAP3 sumaron 127 intervenciones, con la participación de 1853 PAP4 en los siete campi involucrados (Reporte interno del proyecto, 2016).

\section{Educación Ambiental y la Emancipación}

\section{Educación Ambiental Crítica, sus Principales Conceptos y la Cuestión de la Emancipación}

Entre las publicaciones de perspectiva crítica en EA, existe una variedad de referenciales y principios en análisis. Más enfáticamente, a partir de la década de 1990 fueron publicados diversos artículos que muestran una reflexión predominantemente política, aunque todavía con pocas menciones a la cuestión de la emancipación. Y, mismo cuando es mencionada, esta cuestión no es debatida en su complexidad. En algunos casos, la emancipación entra como parte de un anexo al término EA, como, por ejemplo, en EA emancipadora. Un rol de reflexiones parece gravitar 


\section{Sudan \& Zuin - Emancipación y Educación Ambiental}

alrededor de los principios, conceptos y definición de la emancipación cuando diversos autores discuten las praxis de la EA.

Brugger (1994) y Carvalho (2001) apuntan diferencias profundas entre dos vertientes opuestas en la EA; una que es relacionada a educar por el adiestramiento y cambios de comportamiento, mientras que la otra es de una educación que enfatiza los aspectos éticos y políticos de la cuestión ambiental, denominada por Carvalho (2001) como EA Popular, articulados a movimientos sociales de democratización de la educación y del conocimiento a los marginalizados en la sociedad, sobretodo de América Latina. En este sentido, la EA emancipadora es constitutiva de la esfera pública y política. (Carvalho, 2006).

Diversos otros autores y autoras, entre ellos: Lima (1997, 2002, 2003); Sauvé (2005); Layrargues \& Lima (2011), compusieron categorizaciones de vertientes en EA, exponiendo la diversidad de praxis y posibilidades de identificación de discusiones en emancipación. Sauvé (2005) presenta una cartografía de corrientes de mayor tradición en la EA, trayendo más elementos del contexto cultural europeo y norte-americano. De las 15 categorías, tres parecen estar correlacionadas a una perspectiva crítica y emancipadora: 1) práxica (reflexión en la acción para operar un cambio social); 2) feminista (análisis y denuncia de las relaciones de poder de los hombres sobre las mujeres, considerando el estrecho vínculo entre dominación de la naturaleza y de las mujeres) y 3) crítica (inspirada en la teoría crítica, que apunta hacia la transformación de realidades y busca promover procesos emancipadores en la superación de alienaciones). Es en la vertiente crítica que la autora enuncia la emancipación.

A partir del binomio hombre-naturaleza (con categorías centrales del antropocentrismo y del biocentrismo), Lima (1997; 2002; 2003) propone tendencias en diversos formatos en el pensamiento ambiental; posiciones más individualistas o colectivistas y, otras a partir de la relación de la visión de sostenibilidad con educación. La participación social es también señalizada como fundamental en la búsqueda por la emancipación, como algo a ser conquistado, con reconocimiento de los derechos. Sandro Tonso (2005; 2010), así como también Sorrentino (1991) y Ferraro y Sorrentino (2005), profundizan, entre otros aspectos ya puntuados por otros autores, la 
acción social colectiva como dimensión de la EA crítica ${ }^{\mathrm{i}}$, como estrategia metodológica y como opción política de procesos de formación.

Layrargues (2006); Loureiro (2006) y Loureiro, Trein, Tozoni-Reis y Novicki (2009), Santos (2012), Dias, B. (2013) presentan, a partir del enfoque marxista en EA, el trabajo como elemento mediador de la relación humano-naturaleza y de la emancipación. Loureiro, Trein, Tozoni-Reis \& Novicki (2009, p.86) afirman que "la educación ambiental crítica, transformadora y emancipadora emerge de la pedagogía crítica, que tiene su punto de partida en la Teoría Crítica de interpretación de la realidad social", que orienta acciones educativas para la formación humana omnilateral, en contraposición a la formación humana unilateral (resultante de las relaciones sociales de exploración y dominación de la sociedad capitalista). Para esos autores, la pedagogía crítica, a pesar de presentar muchas diferenciaciones en Brasil, también puede ser comprendida por la contribución de dos autores principales: Paulo Freire (1921-1997), con la "educación libertadora" y Dermeval Saviani (nacido en 1944), con la "pedagogía histórico-crítica".

Layrargues \& Lima (2011, p.1), mencionan la cuestión de la emancipación al analizar "tres macro-tendencias conviviendo y disputando la hegemonía simbólica y objetiva del campo de la Educación Ambiental en Brasil: conservacionista, pragmática y crítica". De las tres vertientes, la crítica es aquella que "aglutina las corrientes de la educación ambiental popular, emancipadora, transformadora y, en parte, procesos de gestión ambiental" (Layrargues \& Lima, 2011, p. 11). Ser crítica, para esos autores, incluye revisar los fundamentos del capitalismo, entender los procesos de dominación y exploración del ser humano, enfrentar políticamente las desigualdades y la injusticia socio-ambiental.

La emancipación incluye, según Ferraro (2014), valores libertarios, democráticos y solidarios, una visión de mundo y ambiente como un campo de sentidos socialmente construido y "el debate sobre el acceso y las decisiones relativas a los recursos ambientales", además de "una vinculación afectiva con los valores éticos y estéticos de esta visión de mundo", aunque presente diversas contradicciones internas (Ferraro, 2014, p. 269). Según Loureiro (2007), la emancipación y sus presuposiciones indican una nueva forma de relacionarse con la naturaleza, en el sentido de 


\section{Sudan \& Zuin - Emancipación y Educación Ambiental}

que somos entes biológicos en relación con el mundo, transformándolo y siendo transformados en esa interacción. De esta forma, así como sería equivocado tratar la emancipación como libre de cualquier condicionante social, sería equivocado tratarla como independiente de la comprensión del ser humano como parte de la naturaleza.

Con relación a las diversas denominaciones de la EA - popular, crítica, transformadora - la perspectiva emancipadora a veces aparece en una asociación directa al término EA; o como unas de las características de la EA crítica y popular; o todavía, como un ideal a ser conquistado. Tal vez por la ausencia de profundización sobre el concepto y sentidos de la emancipación, es que no se anuncia muy bien el lugar de ella en relación a la EA, al contrario de la EA popular y crítica, que parecen ocupar con más precisión las discusiones publicadas. De cualquier forma, concordando con Grun (1996), la EA emancipadora surge y se fortalece en negación a una EA conservacionista y conservadora. Y está en la esencia de la educación crítica, transformadora y popular.

\section{La Cuestión de la Emancipación en el Ámbito de la Teoría Crítica}

Bajo la influencia de Kant y Hegel, la Teoría Crítica surgió en los años 30 del siglo XX, con un grupo de intelectuales de un instituto de investigación social en Frankfurt, Alemania, interesado en estudiar las intensas transformaciones de la realidad social de aquella época, a partir de una revitalización del materialismo histórico, en una relación de tensión entre marxismo, Filosofía y Psicoanálisis. Los estudiosos trataron de ampliar la discusión sobre la subjetividad y los cambios en la sociedad y criticaban la uniformización de la existencia individual en la vida moderna. Adorno, Horkheimer, Benjamin y Marcuse son señalados como los filósofos más destacados de esa escuela. Ellos hicieron análisis críticas a la industria cultural, a la fetichización de las mercaderías, a la teoría tradicional y a la semi-formación generalizada fortalecidas en el capitalismo (Pucci, 1994).

Una "democracia, con el deber de operar conforme su concepto, demanda personas emancipadas y solo puede ser imaginada como una sociedad de quien es emancipado", de acuerdo con Adorno (1995, p. 141142). Sin embargo, el concepto de esclarecimiento, o Aufklärung (Kant, 
1985), tan caro para la emancipación, como superación racional de la minoridad y de la tutela, es cuestionado por Adorno (1995), una vez que la presión ejercida sobre las personas por la sociedad hodierna es intensa, a fin de controlar totalmente la realidad, por la vía de la industria cultural y otras coerciones, colocando enormes dificultades para la emancipación y el esclarecimiento en una sociedad administrada.

La autonomía, relacionada directamente a la emancipación, es obstaculizada por el "individualismo, pragmatismo, glorificación de la heteronomía” y por la "idea de adaptación/ajustamiento de los niños desde temprano a la sociedad" (Adorno, 1995, p.171). La autonomía presupone también un contacto con la autoridad (no en el sentido del autoritarismo destructivo) y adquiere su significado en el ámbito del contexto social en que se presenta. Dialécticamente, el psicoanálisis señala que la descubierta de la identidad solo es posible en el encuentro con la autoridad, a partir de la retomada de la socialización en la primera infancia, cuando nos volvemos emancipados psicológicamente. Sin embargo, el proceso de ruptura con la autoridad es necesario y esta etapa de la relación con la autoridad familiar no debe ser glorificada y conservada (Adorno, 1995). Emancipación es, por lo tanto, la decisión consciente independiente, de cada persona en particular. De cierta manera, emancipación significa lo mismo que concientización, racionalidad. (Adorno, 2010, p.9). La persona portadora de una consciencia mutilada, cosificada "cuando convierte la relación humana en cosa, alterando la experiencia” (Adorno, 1995, p.130) porta un carácter autoritario y se aleja de la emancipación. En este sentido, lo contrario de la emancipación sería la barbarie. Según Adorno (1995, p. 137), “el centro de toda educación política debería ser que Auschwitz no se repita. [...] Para eso tendría que transformarse en sociología informando sobre el juego de fuerzas localizado por tras de la superficie de las formas políticas", investigando los perseguidores para revelar los mecanismos de dichos actos, despertando una consciencia general.

La importancia de la Educación - y la responsabilidad de la escuela en el proceso de desbarbarización - está en colocarse contra la identificación ciega con el colectivo. La barbarie deseduca, desfigura y está profundamente presente en las relaciones sociales dominantes. Es a través de la Educación que se desarrolla, por vías complementares, la 


\section{Sudan \& Zuin - Emancipación y Educación Ambiental}

concientización de los mecanismos subjetivos, el proceso de concientizarse de la frialdad del capitalismo y el pasaje de la ignorancia para el conocimiento a través del esclarecimiento, a pesar de las dificultades que la industria cultural impone. La Educación es comprendida como colaboradora de una formación cultural que permita la elaboración de una consciencia crítica sobre la realidad cultural, económica, social e histórica, y sobre todo, la comprensión de los mecanismos de la industria cultural.

Adorno (1995) señala algunos puntos neurálgicos en la Educación: que se dirija a una auto-reflexión crítica, al esclarecimiento general que produce consciencia sobre los motivos que conducen a una barbarie; que destaque el papel de la historia, como proceso educativo; que no premie el dolor ni la capacidad de soportarlo; que no reprima el miedo, "permitiéndose tener tanto miedo cuanto la realidad exige" (p.129); que discuta la relación con la técnica, "no como un fin en sí misma, pero sí como un medio" (p.132); que haga consciente la "frialdad" en la sociedad (p.135), las "participaciones oportunistas" (p.134) motivadas por intereses prácticos individualistas y los "mecanismos subjetivos en general" (p.136); y que fortalezca más a la resistencia que a la adaptación. $O$ sea, es "necesario romper con la educación como mera apropiación de instrumental técnico y recetario para la eficiencia, insistiendo en el aprendizaje abierto a la elaboración de la historia y al contacto con el otro no-idéntico, el diferente" (Maar, 1995, p. 72).

El debate de la emancipación en la Teoría Crítica incluye entenderla como un potencial bloqueado, siempre presente en la sociedad capitalista, con la consideración marxista de que los presupuestos del desarrollo del propio sistema proporcionan las condiciones sociales de su superación (Adorno, 1995; Melo, 2011). De esta forma, la emancipación es una búsqueda que se puede realizar, en la búsqueda por la transformación necesaria de las condiciones materiales de la sociedad.

\section{Método}

Este estudio abarca una investigación empírica con enfoque cualitativo, en el sentido de que pretende investigar aspectos de carácter argumentativofilosófico y desarrollar análisis interpretativas sobre relatos, entrevistas y 
ensayos de un proceso de formación en una institución pública, en el sentido de la ambientalización universitaria y de la emancipación. (Santos Filho \& Gamboa, 2002; André, 2001). Se buscó un método que pudiera dar aporte y considerase la participación intensiva de la investigadora en el proyecto, pudiendo experienciar la tensión entre su práctica de investigación y su práctica pedagógica en la formación de los servidores, con la investigaciónparticipante. La investigación participante nace de una trayectoria compartida entre sujetos e investigador en la práctica de investigación, que se asocia directamente a una práctica política por la busca de transformación de una realidad (Brandão, 1987). En términos identitários, históricos, metodológicos y epistemológicos generales, el diálogo, el trabajo colectivo y la participación popular son implicados en este tipo de investigación, como formas originales y contestatarias, con vocación emancipadora, originada al margen de las universidades $\mathrm{y}$, de cierta forma, como resistencia a las formas tradicionales de investigación social practicadas en ámbito académico (Brandão, 2006). Ese tipo de investigación debe también reflexionar, sobre sus propios fundamentos, presupuestos y conceptos y buscar la emancipación en la sociedad (Tassara \& Ardans, 2006; Sjostrom, Belova, Zuin \& Eilks, 2017).

\section{Participantes de la Investigación}

Todos los participantes de la coordinación del proyecto de Formación Socioambiental de Técnicos Administrativos de esta específica universidad, fueron invitados a participar de esta investigación. Eso ocurrió a partir de la invitación para participar de los grupos focales y de la solicitación de autorización para uso de documentos de ese colectivo. Ese grupo participante - denominado Grupo de Trabajo de Educación Ambiental / GT EA - fue constituido con el total de 44 personas, todas con vínculo con dicha Universidad, de unidades y campi variados. Hay, sin embargo, personas con responsabilidades y formaciones diferenciadas, a) servidores técnicos graduados de diferentes áreas y funciones (educadores, analistas, químicos, 


\section{Sudan \& Zuin - Emancipación y Educación Ambiental}

ingenieros, geógrafos, biólogos y administrativos); b) docentes; c) alumnos de graduación, con becas de extensión (10 horas semanales) y de prácticas (20 horas semanales); d) profesionales graduados contratados, sin vínculo de empleo, como parte del equipo de apoyo al proyecto ${ }^{\mathrm{ii}}$.

\section{Recolección y Análisis de Datos}

Fueron realizados, seleccionados y/o producidos para análisis: documentos elaborados por el grupo del proyecto en el período de 2013 a 2015 (memorias de reuniones y documentos publicados en eventos y en el sitio del proyecto); entrevista colectiva por grupo focal (Dias, C. 2000; Gondim, 2003; Kind, 2004) y sus transcripciones; transcripciones de parte de las reuniones gravadas y notas de observación participante de la investigadora.

Fueron planeados cuatro grupos focales, pero desarrollados de hecho dos. Los encuentros fueron conducidos a partir de un plan previamente elaborado, con flexibilidad en la conducción, considerando su desarrollo en la interacción de la investigadora con el grupo. La forma de registro de los encuentros fue una grabación en audio (para posterior transcripción). Una alumna de graduación dio apoyo a la grabación y actuó como observadora. Del total de 27 reuniones del grupo coordinador, 18 poseen memoria; 14 fueron grabadas y siete, con pautas más reflexivas, fueron transcriptas. Otros documentos complementares fueron analizados en la investigación, tales como: el plan político pedagógico que el grupo produjo a partir de una propuesta inicial del órgano proponente; reporte interno del proyecto (organizado por el órgano proponente) y otras publicaciones.

En este trabajo se buscó una forma de tratamiento de los datos a partir de cuatro focos propuestos por Moraes (2003), que establece una analogía del proceso de análisis a una tempestad de luz. Eso puede ser logrado, según el autor (Moraes, 2003), mediante la atención sobre: a) desmontaje de los textos o promoción de un proceso de fraccionamiento; b) establecimiento de relaciones o categorización entre las unidades; c) captación del nuevo emergente, con la construcción de un meta-texto diferenciado del texto 
original, como un producto de una nueva combinación de elementos, y, por fin, d) auto-organización a partir de los focos anteriores con resultados creativos y originales no previstos, en un esfuerzo dialéctico de lecturas empleadoras de los datos y de extrañamiento crítico posibilitando nuevas comprensiones de los datos.

\section{La Dialéctica de la Emancipación en el Proyecto PAP de Formación Socio Ambiental}

Una de las categorías que se relaciona al objeto central de la tesis es la dialéctica de la emancipación. Para componer un meta-texto sobre ese tema, fueron localizadas en el corpus de la investigación expresiones tales como emancipación, EA Crítica y Emancipadora, autonomía y libertad, escogidas por tener una correlación directa con "emancipación" en el ámbito de la Teoría Crítica. En las centenas de páginas de transcripciones de grupo focal y memorias de reuniones de PAP1, el término "Educación Ambiental Crítica y Emancipadora" aparece seis veces. Ella es enunciada, en los dos primeros extractos, como referencial teórico del proyecto y posición política del GT EA, que debe constar en el PPP, con relación al proceso de formación socio ambiental de servidores técnicos y administrativos de la institución. En el primer grupo focal, este término es definido por los participantes como: "Transformadora" (Fisalis); relacionada a "Paulo Freire" (Cambuci); a la cuestión de la participación y motivadora de una relación de lo ambiental con lo social, puesto que "lo ambiental es solo el inicio, con la cuestión sin lo social, y cuando uno trae todo eso junto, entonces comienza a darle, no sé, una forma diferente para el proceso". (Quinoa, Transcripción grupo focal, 08 de abril de 2015).

El educador Paulo Freire es un referente en Educación Crítica y Popular, sobretodo en América Latina, responsable por la diseminación de los círculos de cultura, de la Educación libertaria y transformadora de realidades injustas y opresoras (Freire, 1996). Según Tonso (2005), Freire y sus reflexiones poseen fuerte interferencia en EA brasilera y en sus propuestas de colectivos educadores, como una resistencia al individualismo y a las desigualdades sociales, propagados en nuestra 


\section{Sudan \& Zuin - Emancipación y Educación Ambiental}

sociedad. Loureiro, Trein, Tozoni-Reis y Novicki (2009) también identifican Paulo Freire (junto con Demerval Saviani) como uno de los principales contribuyentes a la Pedagogía Crítica, por su abordaje de Educación problematizadora de las relaciones sociales de exploración y dominación.

Diversos miembros del GT EA fueron influenciados por experiencias ambientalistas y de Educación Popular, lo que también podría explicar la influencia de Paulo Freire en las personas del grupo y en el proyecto como un todo. Sin embargo, se nota, en parte del grupo (tan heterogéneo, de diversos campos de conocimiento), una influencia del "nombre" sin la debida apropiación de los conceptos debatidos por él, tal como el extracto a seguir explica: "¿[...] no sería importante tener un norte un poco más consolidado de... Alguien... tener formación en el área para auxiliar?... Sabes, daría un... aquel empujoncito, aquella moldada en las formas de trabajo..." (Moringa, Transcripción de la Reunión del GT EA, 05 de febrero de 2014)

De las 13 apariciones de la palabra "emancipación" en el corpus de análisis, cinco se refieren a la consideración de esa temática en listas de contenidos importantes de ser abordados en el proceso de formación de los PAP1, PAP2 y PAP3. En uno de ellos, el término abordado en una reunión del GT EA, se relaciona con metodología y "estrategias que permitan la participación colectiva", al final este "como hacer" debe reflejar una perspectiva teórica. (Memoria reunión, 19 de marzo de 2014, resaltados para análisis). Otras apariciones sobre emancipación, que surgieron en el grupo focal la definen como "libertad" (Quinoa); "autonomía" (Fisális); "un desafío necesario" y "urgente" (Umbu); "es caminada" y no "una dádiva (Pupunha), que a pesar de tener mucho "sentido", también se transformó en "una jerga" (Taioba). Hay asociación de la emancipación con una cierta potencia de agrupamiento y empoderamiento: "no estamos más tan solos, hay mucho más gente que ahora se ve mucho más potente, que va hacia adelante" (Taioba), así como también relacionado a potencia, Cambuci enfatiza que: "es parte de la emancipación sentirse capaz de poder dar el próximo paso" (Transcripción grupo focal, 08 de abril de 2015).

La señalización de emancipación como caminada y construcción, que se realiza en el proceso, retoma Adorno (2010), que entiende que la 
emancipación social no es regalada ni tampoco es fija. Ella es conquistada y factible de sucedernos; pero siempre arriesgada a retrocesos. El autor la identifica, en nuestra sociedad actual, como instantes fugaces, aunque potenciales de transformación, que pueden ser construidos, siempre amenazados de ser absorbidos por el pragmatismo, por el productivismo y la competitividad académicos, por la superficialidad de la industria cultural, por los intereses del mercado que la obstaculizan. La emancipación es asociada, por Cambuci, a una potencia, a una fuerza interior que puede ser desarrollada, que favorece una acción autónoma. Esa fuerza interior, entendida por Adorno (2010) como "firmeza del Yo", es necesaria al proceso de emancipación. Pues en la sociedad capitalista, por más que el individuo parezca seguro en la competencia individualista con los otros, su Yo contiene una debilidad inherente a la formación burguesa, exactamente para que, con fuerzas substraídas, se conforme, se adapte, no resista y no extrañe los padecimientos del capitalismo (Adorno, 2010). Al mismo tiempo, Adorno (2010) advierte que la búsqueda del fortalecimiento del Yo no se puede transformar en un enfoque subjetivista, reduccionista, que ignora las condiciones objetivas de la educación.

Es importante destacar otra ocurrencia asociada a la emancipación, relacionada a la autonomía que cada territorio / campus tendría, o no, en el proceso de desenvolvimiento de la formación. ¿Tendría el proyecto de formación una "identidad de la institución?" ¿O una "identidad del campus?" (Memoria 27 de mayo de 2013, subgrupo de profundización teórica y metodológica). La cuestión de la autonomía de los grupos de PAP2 y PAP3 de los campi fue problematizada en varios momentos en el GT EA, siempre que eso entraba en choque con los acuerdos o directrices colectivas, que no siempre eran consenso y/o plausibles para determinados campi. La vivencia de ese desafío ocurrió desde el principio hasta el final del proyecto, sea con negociaciones colectivas en una perspectiva dialógica, sea con acciones de los campi que negaban los acuerdos generales, sea con recomendación de la mediadora en mantener los acuerdos colectivos, revelando silenciamientos y cuestiones molestas que necesitaban ser trabajadas en el proceso, como advierten los autores Tassara y Ardans (2006) y Pucci (2000). 


\section{Sudan \& Zuin - Emancipación y Educación Ambiental}

Una citación a la emancipación menciona de forma clara la retirada de la presentación sobre "Educación y Emancipación" de la programación del evento integrado de formación de los PAP2 de todos los campi (memoria de la reunión, 19 y 20 de agosto de 2014). Delante de tantos temas, el grupo consideró que la palestra sobre Educación Ambiental ya abordaría contenidos variados, incluyendo el tema de la emancipación. Sin embargo, cabe resaltar que el corpus de análisis no presenta debates consistentes en ese sentido, mostrando una contradicción en un proceso que es anunciado como emancipador. ¿Este corte al tema sería porque los PAP1 ya poseen esos repertorios teóricos hace mucho tiempo, con debates superados? Con seguridad eso se explica para algunos especialistas del GT EA, pero no para su mayoría. En diversos relatos y evaluaciones, los PAP1 señalan la necesidad de profundizar la reflexión teórica. Esa contradicción indica como la semiformación ${ }^{\text {iii }}$ y la superficialidad de los discursos socio ambientales transmitidos por la industria cultural se manifiestan también en la universidad.

Como otra categoría relacionada a la emancipación, la palabra autonomía fue buscada e identificada en 13 extractos del corpus. Un extracto se repite al de la emancipación y cinco se refieren a la tomada de decisiones sobre el sitio del Proyecto PAP. Un extracto está relacionado al hecho de que cada campus tiene autonomía para escoger sus temas para profundización. En otro extracto, la palabra es usada para recomendar que los grupos de PAP de cada campus presenten sus propias propuestas de actividades. La palabra autonomía también es usada en un texto sobre lo que es ser PAP1, anunciando la búsqueda por: "Fomentar autonomía de los servidores de la institución, de manera que asuman las actividades educadoras dirigidas a la sostenibilidad socio ambiental en la Universidad y en la Sociedad" (Memoria de reunión, 05 de febrero de 2014). Con la priorización de ese público (servidores técnicos y administrativos) en la formación, el proyecto adquirió un carácter alternativo e innovador en el ámbito de la institución, considerando que, en general, ella es priorizada a los alumnos y docentes. Sin embargo, Tassara y Ardans (2006, p.64) advierten para repercusiones institucionales sobre el papel de cada uno dentro de un colectivo educador. Como técnicos de la institución, los participantes del proyecto se encuentran en una posición delicada, "en esa 
dialéctica do poder y participación" y una necesidad permanente de articular sus conductas a los impactos relacionales del trabajo. Autonomía, libertad, posiciones políticas y relaciones de poder se entrecruzan en el cotidiano de la institución.

Otro aspecto relacionado a la cuestión de la autonomía se refiere a la actividad de tutoría de los PAP1 a los PAP2 y de los PAP2 a los PAP3, actividad esta que fue programada para dar soporte a los PAP con el objetivo de formar otras personas en la capilaridad, en un reconocimiento de la complexidad pedagógica involucrada. La inseguridad manifestada por los PAP2, para desarrollar solos una práctica, era acogida y trabajada en las reuniones de tutoría con docentes convidados, o con los propios PAP1 del campus. Sin embargo, es posible que esa tutoría hubiera excedido fronteras en eventuales grupos y/o momentos en que, debido a la inseguridad y ansiedad de algunos PAP1, se transformó en "conducir la situación por los PAP2, para que estos errasen menos" (Taioba). En esos casos, tal vez la tutoría se hubiera transformado en "tutela", que obstaculiza la salida de la "menoridad", segundo Kant (1985), indicando que no todos los PAP tenían autonomía para actuar y pensar por sí mismos. Por otro lado, muchos de los PAP pueden haber ampliado su autonomía, con un cierto fortalecimiento del Yo (Adorno, 1995), cuando provocados por el acto de coordinar una intervención educadora, teniendo que dar un salto cualitativo de la dificultad inicial de manifestarse públicamente y exponer sus propias ideas y evaluaciones, planear y actuar colectivamente en la promoción de un curso y profundizarse en el tema en foco.

La libertad, otra dimensión de la emancipación, implica la liberación de algo concreto, en un contexto real, dentro de la historia y de la naturaleza. En la sociedad contemporánea, ser libre significa romper con las formas de expropiación material (exclusión social y desigualdad de clase) y de dominación y con los preconceptos de etnia, género o cualquier otra identidad posible en una cultura (Loureiro, 2007, p.160).

Sin embargo, no es un proceso apenas interno; lo que sería individualismo, falsa libertad, aislamiento y olvido del otro, de la sociedad y del mundo (Adorno, 1995). La libertad se realiza en las relaciones, como seres colectivos que somos, en la existencia de una cultura. Asociada a ella está la democracia - también parte del ideario de emancipación - y en su 


\section{Sudan \& Zuin - Emancipación y Educación Ambiental}

concepto se presupone la capacidad de definir las reglas de convivencia social y responsabilidad en la relación; implicando en salir de la comodidad en pro del bien común. (Loureiro, 2007).

De los siete extractos que incluyen la palabra libertad, uno presenta también referencia a la autonomía, tres involucran la elección de temas para los proyectos y acciones en cada campus. Otros dos abordan la construcción colectiva del logotipo y del sitio del proyecto. El grupo de comunicación estaba dedicado a producir un logotipo en que todo el colectivo "se pudiera ver". Pero también reclamaba por más libertad para decidir sobre él, ya que había sido invitado a liderar el proceso junto a la empresa contratada para diseñarlo y ahora estaba siendo discordado en sus ideas por la facilitadora y por el GT EA. "Mi verdadero miedo es... ahora voy a tener que animarme con la empresa y ahora voy a tener que tener un poco de libertad, porque si no las cosas no avanzan" (Guabiroba, Transcripción de la reunión, 20 de agosto de 2014).

El concepto de libertad nos ayuda a entender que ella no existe fuera de las relaciones, dando a cada uno el poder de hacer lo que quiera, más bien al contrario, nos desafía a realizarla en el ejercicio de la búsqueda, de la convivencialidad, de las divergencias de opiniones y de la transformación de realidades adversas. La libertad encuentra "dificultad de realizarse delante de su condición revolucionaria que se opone a un sistema hegemónico de concentración de poder, para el cual la movilización de las personas representa un peligro concreto" (Zerbini, 2008, p.167); aspectos estos que alimentaban los temores del GT EA en la relación con los dirigentes de la institución, en el cambio de gestión del propio órgano de gestión proponente y en las mediaciones que necesitaban hacer para enfrentar obstáculos de la burocracia, de la jerarquía y de la centralización de poderes.

Sin embargo, el Proyecto PAP revela destellos emancipadores por su criticidad al priorizar un público técnico y administrativo entendido como "aquel que solamente ejecuta" dentro de la institución, en una formación con propuesta emancipadora, en un sentido dialógico y colectivo, con posibilidades para crear sus propios proyectos educativos en colectivos educadores. Además de eso, ejercitó la dialéctica de la autonomía y de la libertad en sus meandros, en la ejecución de cursos e intervenciones de 
servidores para servidores, y en la reconstrucción colectiva del proyecto por el grupo coordinador - PAP1, persistiendo en su continuidad e implementación en relación a las burocracias, jerarquías y diferentes intereses internos al propio grupo; en la tensión entre reconocer la falta de formación en el área y tener que programar una formación educadora socio ambiental junto a la totalidad de los servidores técnicos y administrativos de la institución.

\section{Consideraciones Finales y Perspectivas}

El objetivo de este trabajo fue identificar elementos dialécticos emergentes de un proyecto educativo como indicativos de potencial emancipador en la formación socio-ambiental de servidores de una Institución Pública de Educación Superior del Estado de São Paulo, Brasil. Con base en los datos obtenidos, y a pesar de las dificultades enfrentadas, es posible afirmar que el Proyecto PAP contribuyó con la institución promotora, potencializando acción colectiva, reflexiones, indagaciones y una actuación diferenciada de la tradición relacionada a la EA comúnmente practicada. El ejercicio colectivo en EA universitaria posibilita locus de desafíos de la convivencialidad y de la formación reflexiva autocrítica. Comprendiendo la EA Emancipadora como aquella que potencializa una resistencia a la racionalidad instrumental y al sistema de producción corriente, ella busca politizar los procesos formativos y dar un salto en la superación del senso común sobre las cuestiones socio ambientales en la institución.

Una propuesta de EA que tiene en pauta la emancipación no puede prescindir de la reflexión crítica y autocrítica, de la búsqueda por la superación de realidades degradantes, en pro del bien común. Por lo tanto, una EA emancipadora ya abarca la cuestión de la criticidad, de la autonomía, de la libertad, de la transformación, abriendo un debate que necesita ser validado colectivamente, sobre las designaciones "EA crítica", "EA transformadora" y "EA emancipadora" y sus relaciones.

La emancipación, al contrario de sueño idealizado, es un proceso dialéctico en movimiento con posibilidades concretas de realización. Es utopía factible, en el ejercicio de la autonomía, en la búsqueda de la libertad, en el encuentro de la resistencia individual y colectiva, en la 


\section{Sudan \& Zuin - Emancipación y Educación Ambiental}

búsqueda por la superación de las contradicciones de una dada realidad. Es una categoría que puede venir a suceder concretamente, así como se puede perder, dentro de dadas condiciones sociopolíticas y económicas. Eso nos reanima en la caminata de la EA y del ambientalismo al mismo tiempo en que aclara el tamaño de la resistencia que hay que enfrentar.

La resistencia de los educadores ambientales a dichas obstaculizaciones colocadas por la institución para la emancipación puede fortalecerse con una EA que aborde la contradicción. En ese sentido, Adorno (2010, p.182) afirma que "la única concretización efectiva de la emancipación consiste en que aquellas pocas personas interesadas en este sentido dirijan toda su energía para que la educación sea una educación para la contradicción y para la resistencia". Y es en este sentido que el colectivo investigado nos indicó a apuntar.

\section{Agradecimientos}

Las autoras agradecen el apoyo de la Universidade Federal de São Carlos (UFSCar) y del CNPq (procesos: 311000/2014-2, 421096/2016-0 y 310149/2017-7).

\section{Notas}

i. Fundamentada en los círculos de cultura de Paulo Freire y en las comunidades aprendentes de Carlos Rodrigues Brandão (TONSO, 2005).

ii. Con el fin de preservar el anonimato de los participantes, fueron establecidos nombres en clave relacionando cada uno de ellos a Plantas Alimenticias No Convencionales (PANC) brasileñas. Los campi, de diferentes ciudades, fueron indicados por números de 1 a 7 .

iii. Los conceptos de semiformación e industria cultural son profundizados en múltiples obras Teórico- Críticas y, más específicamente en las obras clásicas "Teoría de la Semiformación", de Theodor Adorno (2010) y "La Industria cultural: el esclarecimiento como mistificación de las masas" en: Dialéctica del Esclarecimiento/ fragmentos filosóficos. Max Horkheimer \& Theodor Adorno (1985). La industria cultural es discutida como un sistema mediático capaz de promover alienación y dependencia de las personas por medio de la oferta de un exceso de información e ilustración y establecerse como un instrumento de control social, dominación y poder. Por su lado, la teoría de la Semiformación aborda la crisis de la formación cultural en el capitalismo, representando el culto a la mercadería y la banalización de los bienes culturales. 
REMIE-Multidisciplinary Journal of Educational Research, 8(2)225

\section{Referencias}

Adorno, T. W. (1995). Educação e Emancipação (3rd ed). Rio de Janeiro RJ: Paz e Terra.

Adorno, T. W. (2010). Teoria da Semiformação. In B. Pucci, A. S. Zuin, \&L. A. C. N. Lastória (Eds.). Teoria e Inconformismo: Novas Perspectivas e Pesquisa (pp. 7-40). Campinas - SP: Autores Associados.

André, M. (2001). Pesquisa em educação: buscando rigor e qualidade.

Cadernos de Pesquisa, 113, 51-64. doi.10.1590/S010015742001000200003

Brandão, C. R. (1987). Participar-pesquisar. In C. R. Brandão (Eds.). Repensando a Pesquisa Participante (3rd ed., pp. 7-14). São Paulo SP: Brasiliense.

Brandão, C. R. (2006). A pesquisa participante e a participação da pesquisa: um olhar entre tempos e espaços a partir da América Latina. In C. R. Brandão, \& D. R. Streck (Eds.). Pesquisa Participante: a Partilha do Saber (pp. 21-54). Aparecida - SP: Ideias \& Letras.

Brasil. Ministério Do Meio Ambiente, Ministério da Educação. (2006).

Programa Nacional de Formação de Educadoras(es) Ambientais ProFEA. Brasília - DF: Secretaria Executiva. Recuperado de: http://www.mma.gov.br/estruturas/educamb/_arquivos/dt_08.pdf

Brügger, P. (1994). Educação ou Adestramento Ambiental? Florianópolis SC: Letras Contemporâneas.

Carvalho, I. C. M. (2001). Qual educação ambiental? Elementos para um debate sobre Educação Ambiental e extensão rural. Agroecologia e Desenvolvimento Rural Sustentável, 2(2), 43-51.

Carvalho, I. C. M. (2006). Atitude, comportamento e ação política: elementos para pensar a formação ecológica. In I. C. M. Carvalho. A Formação do Sujeito Ecológico (2nd ed., pp. 176-191). São Paulo SP: Cortez.

Carvalho, I. C. M., Farias, C. R. O (2011). Um balanço da produção científica em Educação Ambiental de 2001 a 2009 (Anped, Anppas e 
EPEA), Revista Brasileira de Educação, 16, 119-134. doi.10.1590/S1413-24782011000100007

Carvalho, L. M., Tomazello, G., \& Oliveira, H. T. (2009). Pesquisa em Educação Ambiental: Panorama da produção brasileira e alguns de seus dilemas. Cedes, 29, 13-27. doi.10.1590/S010132622009000100002

Costa, P. A. \& Silva Maia, J. S. (2017). Uma leitura da educação ambiental crítica no periódico Environmental Education Research por meio da revisão sistemática. In IX Encontro Pesquisa em Educação Ambiental. EA e questões epistemológicas. Políticas Públicas, democracia, práticas educativas (0170, pp10). Anais... Juiz de ForaMG: Universidade Federal de Juiz de Fora. Recuperado de: http://epea.tmp.br/epea2017_anais/list/

Dias, B. C. (2013). Em busca de uma práxis em Educação Ambiental Crítica: Contribuições de alguns pesquisadores do Brasil (Dissertação de Mestrado em Ensino de Ciências). Rio de Janeiro RJ: Instituto Federal de Educação, Ciência e Tecnologia do Rio de Janeiro (IFRJ), Campus Nilópolis.

Dias, C. A. (2000). Grupo Focal: Técnica de coleta de dados em pesquisas qualitativas. Informação \& Sociedade, 10, 141-158.

Faria, J. H., \& Meneghetti, F. K (2011). Dialética negativa e a tradição epistemológica nos estudos organizacionais. Organizações \& Sociedade, 18(56), 119-137. doi.10.1590/S198492302011000100006

Ferraro Junior, L. A. (2014). Incorporação da questão ambiental na universidade vista a partir de dentro da gestão ambiental do Estado. In A. Ruscheinsky, A.F.S. Guerra, M.L. Figueiredo, P.C.S. Leme, V.E.L. Ranieri \& W.B.C. Delitti. Ambientalização nas instituições de educação superior no Brasil: caminhos trilhados, desafios $e$ possibilidades (pp. 262-279). São Carlos - SP: EESC/USP.

Ferraro Junior, L. A., \& Sorrentino, M. (2005). Coletivos educadores. In L. A. Ferraro Junior (Eds.). Encontros e Caminhos: Formação de Educadoras(es) Ambientais e Coletivos Educadores, 1, (pp. 57-69). Brasília - DF: MMA, Diretoria de Educação Ambiental. 
Freire, P. (1996). Pedagogia da autonomia: saberes necessários à prática educativa, 7th ed. São Paulo - SP: Paz e Terra.

Goergen, P. (2010). Teoria e ação no GT Educação Ambiental da Anped: partilhando algumas suspeitas epistemológicas. Pesquisa em Educação Ambiental, 5(2), 9-30. doi.10.11606/issn.2177580X.v5i2p09-30

Gondim, S. M. G. (2003). Grupos focais como técnica de investigação qualitativa: Desafios metodológicos. Paidéia, 12(24), 149-161. doi.10.1590/S0103-863X2002000300004

González-Gaudiano, E. J., \& Lorenzetti, L. (2009). Investigação em Educação Ambiental na América Latina: Mapeando tendências. Educ. Rev., 25(3), 191-211. doi.10.1590/S0102-46982009000300010 Grün, M. (1996). Ética e Educação Ambiental: a Conexão Necessária, 11 ed., Campinas - SP: Papirus.

Kant, I. (1985). Resposta à pergunta: o que é esclarecimento? In I. Kant. Textos seletos (2nd ed, pp. 100-117). Petrópolis - RJ: Vozes.

Kind, L. (2004). Notas para o trabalho com a técnica de Grupos Focais, Psicologia em Revista, 10(15), pp. 124-126.

Layrargues, P. P. (2006). Muito além da natureza: Educação Ambiental e reprodução social. In C. F. B. Loureiro, P. P. Layrargues, \& R. C. Castro De (Eds.). Pensamento Complexo, Dialética e Educação Ambiental (pp. 72-103). São Paulo - SP: Cortez.

Layrargues, P. P., \& Lima, G. F. C. (2011). Mapeando as macrotendências políticos-pedagógicas da educação ambiental contemporânea no Brasil. In VI Encontro "Pesquisa em Educação Ambiental” - EPEA. A pesquisa em Educação Ambiental e a Pós-graduação no Brasil, Ribeirão Preto - SP Anais. (pp.1-15), Ribeirão Preto: Universidade de São Paulo.

Lima, G. F. C. (1997). O debate da sustentabilidade na sociedade insustentável. Política e Trabalho, 13, 201-222.

Lima, G. F. C. (2002). Crise ambiental, educação e cidadania: os desafios da sustentabilidade emancipatória. In P. P. Layrargues, R. S. Castro, \& C. F. B. Loureiro (Eds.). Educação Ambiental: Repensando o Espaço da Cidadania (pp. 109-142). São Paulo - SP: Cortez. 
Lima, G. F. C. (2003). O discurso da sustentabilidade e suas implicações para a educação. Ambiente \& Sociedade, 6(2), 99-119. doi.10.1590/S1414-753X2003000300007

Loureiro, C. F. B. (2006). Trajetória e fundamentos da Educação Ambiental. São Paulo - SP: Cortez.

Loureiro, C. F. B. (2007). Emancipação e Complexidade: para o repensar das tendências em educação ambiental. In Ministério do Meio Ambiente. Encontros e Caminhos: Formação de educadoras(es) ambientais e coletivos educadores. Cadernos de Educação, 2, 157170. Recuperado de:

http://www.mma.gov.br/estruturas/educamb/_arquivos/encontros_2.p df . Aceso en 15 mar. 2016.

Loureiro, C. F. B., Trein, E., Tozoni-Reis, M. F. C., \& Novicki, V. (2009). Contribuições da teoria marxista para a educação ambiental crítica. Cadernos Cedes, 29(77), 81-97. doi.10.1590/S010132622009000100006

Maar, W. L. (1995). Educação crítica, formação cultural e emancipação política na Escola de Frankfurt. In B. Pucci (Eds.). Teoria crítica e Educação: a Questão da Formação Cultural na Escola de Frankfurt (2nd ed., pp. 59-82). Petrópolis-RJ: Vozes, São Carlos - SP: Edufscar.

Melo, R. (2011). Teoria Crítica e os sentidos da emancipação. Caderno CRH, 24(62), 249-262.

Moraes, R. (2003). Uma tempestade de luz: a compreensão possibilitada pela análise textual discursiva. Ciência \& Educação, 9(2), 191-211. doi10.1590/S1516-73132003000200004

Pucci, B. (2000). Considerações extemporâneas acerca das metodologias qualitativas. Comunicações, 7(1), 255-259.

Santos Filho, J. C., Gamboa, S. S. (Eds.) (2002). Pesquisa educacional: quantidade - qualidade (5th ed.). São Paulo - SP: Cortez.

Santos, A. M. M. (2012). As contradições das relações de produção no cooperativismo da reciclagem: contribuições à práxis socioambiental crítica (Tese Doutorado). Rio de Janeiro - RJ: Instituto de Psicologia - Universidade Federal do Rio de Janeiro. 
Sauvé, L. (2000). Para construir un patrimonio de investigación en

Educación Ambiental. Tópicos en Educación Ambiental, 2(5), 51-69.

Sauvé, L. (2005). Uma cartografia das correntes de educação ambiental. In

M. Sato, \& I.C.M. Carvalho (Orgs.). Educação Ambiental -

Pesquisas e Desafios. Porto Alegre - RS: Artmed.

Sjöström, J., Frerichs, N., Zuin, V., \& Eilks, I. (2017). Use of the concept of Bildung in the international science education literature, its potential, and implications for teaching and learning. Journal Studies in Science Education, 1-28. doi.10.1080/03057267.2017.1384649

Sorrentino, M. (1991). Educação ambiental, participação e organização. Em Aberto, 10 (49), 46-56.

Sudan, D. C. (2017). Educação Ambiental e Teoria Crítica: A Dialética da Emancipação na Formação Socioambiental de servidores de uma universidade pública do estado de São Paulo. (Tese Doutorado em Educação). São Carlos - SP: Programa De Pós-Graduação Em Educação / PPGE, Universidade Federal de São Carlos.

Tassara, E. T. O., \& Ardans, H. O. (2006). Educação ambiental crítica: pesquisa-ação, participação, silêncios e silenciamentos. Pesquisa em Educação Ambiental, 1 (1), 59-71. doi.10.11606/issn.2177-

580X.v1i1p59-71

Tonso, S. (2005). Cardápio de Aprendizagem. In L.A. Ferraro Júnior (Ed). Encontros e Caminhos: Formação de educadoras (es) ambientais e coletivos educadores (Vol. 1, pp. 47-56). Brasília - DF: MMA, Diretoria de Educação Ambiental.

Tonso, S. (2010). A Educação Ambiental que desejamos a partir de um olhar para nós mesmos. Ciência em Foco, 1 (3), 1-15.

Zerbini, F. M. (2008). Emancipação e ambientalismo: um estudo sobre fundamentos para uma Educação Ambiental crítica (Tese Doutorado em Ciência Ambiental). São Paulo - SP: Programa de Pós-Graduação em Ciência Ambiental, Universidade de São Paulo.

Zuin, V. G.; Pacca, J. L. A. (2013). Formación docente en química y ambientación curricular: estudio de caso en una institución de enseñanza superior brasilera. Enseñanza de las Ciencias, 31, 77-91. 
230 Sudan \& Zuin - Emancipación y Educación Ambiental

Daniela Cassia Sudan es Doctora por el Programa de Postgrado de la Universidad Federal de São Carlos (UFSCar), São Carlos - SP, Brasil. https://orcid.org/0000-0002-0861-1055

Vânia Gomes Zuin es Profesora del Departamento de Química, (FRSC, CNPq-PQ), de la Universidad Federal de São Carlos (UFSCar), São Carlos - SP, Brasil. Y invitada de la Universidad de York, UK

https://orcid.org/0000-0003-4452-4570

Contact Address: Daniela Cassia Sudan. Programa de Pós Graduação em Educação (PPGE). Centro de Educação e Ciências Humanas (CECH). SP-310 | São Carlos-SP | Brasil. CEP: 13.565-905

Phone: +55 (16) 3351-8351

E-mail: danisudan@usp.br 


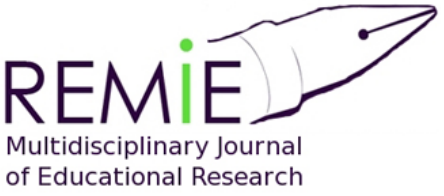

Multidisciplinary Journal of Educational Research
Hipatia Press

www.hipatiapress.com

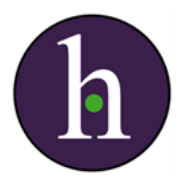

Instructions for authors, subscriptions and further details:

http://remie.hipatiapress.com

\section{Collaborative, Participatory and Empowerment Evaluation: Stakeholder Involvement Approaches.}

Chantae D. Still ${ }^{1}$

1) University of South Florida, United States.

Date of publication: June $15^{\text {th }}, 2018$

Edition period: June 2018 - October 2018

To cite this article: Still, C. (2018). Collaborative, Participatory and Empowerment Evaluation: Stakeholder Involvement Approaches. [Review of the book]. REMIE-Multidisciplinary Journal of Educational Research, 8(2), 231-233. doi:10.17583/remie.2018. 3465

To link this article: http://dx.doi.org/doi:10.17583/remie.2018.3465

\section{PLEASE SCROLL DOWN FOR ARTICLE}

The terms and conditions of use are related to the Open Journal System and to Creative Commons Attribution License (CC-BY). 
REMIE - Multidisciplinary Journal of Educational Research Vol. 8

No. 2 June 2018 pp. 231-233

\section{Review}

Fetterman, D. M., Rodriguez-Campos, L., \& Zukoski, A. P. (2018). Collaborative, Participatory and Empowerment Evaluation: Stakeholder involvement approaches. New York, NY: The Guilford Press. ISBN: 978-1462-53282-7.

As the field of Evaluation has grown, additional recognition has been given to the importance of stakeholder involvement. In the book Collaborative, Participatory, and Empowerment Evaluation: Stakeholders Involvement Approaches, Fetterman, Rodriguez-Campos, Zukoski and their contributors provide an overview of these three approaches which enhance capacity building and capacity use through creating environments that foster respect and appreciation for people and provide opportunities for stakeholders to engage in making improvements with the help of an evaluator. The book itself is very functional and easy to read. Its 12 chapters are organized into what I would describe as four main parts. Excluding the introduction and conclusion, the book provides the essentials of each approach followed by examples of how that approach was utilized. For example, after Chapter 2 Essentials of Collaborative Evaluation, which explains the Model for Collaborative Evaluation (MCE) framework, principles, roles, and steps to conducting an evaluation using this approach, the following two chapters highlight a collaborative evaluation that was conducted on a Marine Life Program and a multisite multiyear evaluation of an Early Childhood Quality Care Initiative that was conducted using the collaborative approach. After the reader is thoroughly educated on the three approaches, the fourth section of the book focuses attention on the similarities of all three approaches and concludes with a review of how the approaches may continue to evolve in the future. 
I was very familiar with the collaborative approach and interested in learning more about how the other two approaches function, how stakeholders respond to their involvement in the other two approaches, and how the three approaches have been used within community programs, an area on which I intend to focus future evaluation efforts. The area of the book that I found personally helpful to my interests was chapter 9: An Empowerment Evaluation of a Comprehensive Sex Education Initiative. In addition to explaining the steps and stages of the empowerment evaluation, the chapter was laced with quotes from stakeholders who gave an account of their experience learning, working, and coming to respect Empowerment evaluation and their "Critical Friend" (i.e. a coach instead of an expert, who believes in the program and has the evaluation knowledge p.75).

Identifiable limitations could be related to the lack of detail about the example evaluation quantitative data specifics; however, I do not view this to be a shortcoming. The authors provided a great overview instead of going in depth about the specific evaluations and thus for made this book more of a practitioner's tool, which is in line with the American Evaluation Association's mission of improving evaluation practices and methods. My one suggestion would be in reference to consistently have a Lessons Learned section following each example evaluation. Documenting the lessons learned throughout an evaluation is very helpful to the success of future evaluation design. If a Lessons Learned section followed each evaluation example in the book, readers would have gained an additional level of knowledge about things to consider when encountering similar situations.

Collaborative, Participatory, and Empowerment Evaluation makes a major contribution to the evaluation field. It organizes the essentials of three well respected approaches in one affordable book that demonstrates how these approaches can be used to evaluate individual or comprehensive programs or initiatives, nationally or internationally. This book would also appeal to the field of Adult Education. Involving stakeholders in evaluations of continuing education programs and community initiatives is an approach that can be successfully utilized with the help of the models, instructions and examples in this publication. For the novice evaluator like myself it provides more than enough insight and clarification about the 
approaches to help identify which one would be best suited to meet the needs of the stakeholders who have sought my services. For the experienced evaluator, it would be a reference guide of sorts. Though it may not contribute any new knowledge about the approaches, it provides great examples of evaluations, some information about lessons learned while working on some of these evaluations and a great synthesis of how the principles of the three approaches intersect and complement certain methods and skills. I would recommend this book to students, beginning evaluators and expert professionals.

Chantae D. Still, University of South Florida, Tampa, FL, USA https://orcid.org/0000-0002-8029-6125 chantaestill04@yahoo.com 